INTERNATIONAL

FOOD POLICY

RESEARCH

INSTITUTE

IFPRI

IFPRI Discussion Paper 01480

November 2015

\title{
The Food-Energy-Water Security Nexus
}

Definitions, Policies, and Methods in an Application to Malawi and Mozambique

Thea Nielsen, Franziska Schuenemann, Emily McNulty,

Manfred Zeller, Ephraim Nkonya, Edward Kato,

Stefan Meyer, Weston Anderson, Tingju Zhu, Antonio Queface, and Lawrence Mapemba

Environment and Production Technology Division 


\section{INTERNATIONAL FOOD POLICY RESEARCH INSTITUTE}

The International Food Policy Research Institute (IFPRI), established in 1975, provides evidence-based policy solutions to sustainably end hunger and malnutrition and reduce poverty. The Institute conducts research, communicates results, optimizes partnerships, and builds capacity to ensure sustainable food production, promote healthy food systems, improve markets and trade, transform agriculture, build resilience, and strengthen institutions and governance. Gender is considered in all of the Institute's work. IFPRI collaborates with partners around the world, including development implementers, public institutions, the private sector, and farmers' organizations, to ensure that local, national, regional, and global food policies are based on evidence. IFPRI is a member of the CGIAR Consortium.

\section{AUTHORS}

Thea Nielsen is a scientific assistant at the Chair of Rural Development Theory and Policy, University of Hohenheim, Stuttgart, Germany.

Franziska Schuenemann is a $\mathrm{PhD}$ candidate at the Chair of Rural Development Theory and Policy, University of Hohenheim, Stuttgart, Germany.

Emily McNulty is a PhD candidate at the Chair of Rural Development Theory and Policy, University of Hohenheim, Stuttgart, Germany.

Manfred Zeller is head of policy research for HarvestPlus, Kampala, Uganda.

Ephraim Nkonya is a senior research fellow in the Environment and Production Technology Division of the International Food Policy Research Institute (IFPRI), Washington, DC.

Edward Kato is a senior research assistant in the Environment and Production Technology Division of IFPRI, Washington, DC.

Stefan Meyer (s.meyer@cgiar.org) is an associate research fellow in the Environment and Production Technology Division of IFPRI, Lilongwe, Malawi.

Weston Anderson is a $\mathrm{PhD}$ candidate at Lamont Doherty Earth Observatory, Columbia University, New York.

Tingju Zhu is a research fellow in the Environment and Production Technology Division of IFPRI, Washington, DC.

Antonio Queface is a senior lecturer in Climatology and researcher at the Eduardo Mondlane University, Maputo, Mozambique.

Lawrence Mapemba is a senior lecturer in Agricultural and Applied Economics, Lilongwe University of Agriculture and Natural Resources, Lilongwe, Malawi.

\section{Notices}

1. IFPRI Discussion Papers contain preliminary material and research results and are circulated in order to stimulate discussion and critical comment. They have not been subject to a formal external review via IFPRI's Publications Review Committee. Any opinions stated herein are those of the author(s) and are not necessarily representative of or endorsed by the International Food Policy Research Institute.

2. The boundaries and names shown and the designations used on the map(s) herein do not imply official endorsement or acceptance by the International Food Policy Research Institute (IFPRI) or its partners and contributors.

Copyright 2015 International Food Policy Research Institute. All rights reserved. Sections of this material may be reproduced for personal and not-for-profit use without the express written permission of but with acknowledgment to IFPRI. To reproduce the material contained herein for profit or commercial use requires express written permission. To obtain permission, contact ifpri-copyright@cgiar.org. 


\section{Contents}

Abstract $\quad$ V

Acknowledgments $\quad$ vi

1. Introduction 1

2. Nexus Interventions in Malawi and Mozambique 7

3. Macrolevel Analysis of Nexus Interventions 27

4. Microlevel Analysis of Nexus Interventions 38

5. Conclusions 50

References 51 


\section{Tables}

1.1 Examples of nexus interventions 4

2.1 FISP investment

2.2 Impact of fertilizer subsidies in Malawi $\quad 10$

2.3 Comparison of fertilizer usage of selected SSA countries 12

2.4 Source of energy for rural population in SSA (\% of households) 16

2.5 Increasing deforestation in Africa south of the Sahara 20

2.6 Main energy sources used for cooking in Mozambique (\%) 22

2.7 Usage of cookstove type in Mozambique (in percent) 23

3.1 Criteria and data for ex ante suitability analysis 33

3.2 Criteria for evaluating a pixel as entirely unsuitable for irrigation 33

4.1 Independent variables in the binary choice model and their expected signs 41

4.2 Land tenure in Malawi $\quad 42$

4.3 Characteristics of input use and enterprises in Malawi 43

4.4 Drivers of irrigation and fertilizer adoption in Malawi $(\mathrm{N}=10,360) \quad 44$

4.5 Drivers of energy choice in rural Malawi $(\mathrm{N}=9,462)$

4.6 Sources of cooking energy in Mozambique (in percentage, using source) 46

4.7 Drivers of fertilizer use in Mozambique 47

4.8 Drivers of cooking energy source in Mozambique $(\mathrm{N}=10,798) \quad 48$

4.9 Drivers of irrigation, Mozambique $(\mathrm{N}=5,783)$

\section{Figures}

1.1 Conceptual framework of the FEW nexus 2

2.1 Per capita production in Malawi, Mozambique, and SSA regions 8

2.2 Daily protein supply in Malawi, Mozambique, and Southern Africa 8

2.3 Energy supply in Malawi, Mozambique, and Southern Africa 9

2.4 Types of cooking stoves: clay, rocket, and three-stone traditional 23

2.5 Comparison of fuelwood consumption and cooking time for cooking stoves 24

2.6 Distribution of cookstove programs in Africa south of the Sahara, 1984-2010 24

3.1 Circular flow of income in an economy 28

3.2 Ex ante analysis scoring $\quad 34$

3.3 No market constraints $\quad 36$

3.4 Full parameterization (includes all constraints) 36

3.5 No market constraints, no groundwater, and surface runoff included 36

3.6 No market constraints, no runoff, and groundwater available to $7 \mathrm{~m}$ below ground only $\quad 36$

3.7 Sensitivity analysis as a function of linear shifts in the scoring function of each variable for the fully parameterized motor-pump model for all of SSA 37

4.1 Adoption of soil fertility management and irrigation in Mozambique 46 


\begin{abstract}
This study summarizes the concept of the food-energy-water security nexus (FEW nexus). The aim is to create awareness about the importance of the nexus and to enable stakeholders to consider interconnections between the sectors in their work. The FEW nexus is discussed in the context of Africa south of the Sahara (SSA) - using Malawi and Mozambique as case studies.

Even though analyzing food, energy, and water security issues simultaneously is critical given the interconnections, summarizing interventions with the FEW nexus approach in Malawi and Mozambique, we found that there are only a limited number of interventions in place.

Additionally, this study reviews macro- and microeconomic models that are able to analyze the FEW nexus. On the macrolevel, especially general equilibrium models are discussed, because they show trade-offs and synergies of nexus interventions at all economic levels. These models can help guide policymakers' understanding of nexus effects ex ante and convince them to think beyond their respective political departments. On the microlevel, the impact of nexus interventions can be assessed with qualitative and quantitative approaches. There are specific challenges for nexus interventions when it comes to aggregation and planning of the targeting. A secondary data analysis of nexus interventions shows that existing data is not sufficient to conduct research specifically related to the FEW nexus.

The results of this study will help research programs to reflect the key questions required to enhance adoption of FEW technologies and inform policymakers as they formulate policies that will exploit the strong synergies of food security, energy, and water investments.
\end{abstract}

Keywords: food-energy-water security nexus, nexus intervention, simultaneous analysis, Malawi, Mozambique 


\section{ACKNOWLEDGMENTS}

This work was undertaken as part of the CGIAR Research Program on Policies, Institutions, and Markets (PIM) led by the International Food Policy Research Institute (IFPRI). We gratefully acknowledge generous funding from the Federal Ministry for Economic Cooperation and Development (BMZ) and the important contributions of our collaborating institutions, particularly Universidade Eduardo Mondlane in Mozambique and Lilongwe University for Agriculture and Natural Resources (LUANAR) in Malawi. We are greatly indebted to farmers and farmer groups who participated in this study and to the enumerators who collected data. The time they offered to answer questions and invite the research teams into their homes is highly appreciated. This work also benefited from comments of the participants of the Mid-Term Workshops in Lilongwe and Maputo. We are grateful for the input of Siwa Msangi, Christa Roth, James Thurlow, Timothy Johnson, Karl Pauw and the Malawi Strategy and Support Program (MaSSP) team for their direct and indirect support to this project. We thank Maeve for providing data and information related to fuel-efficient cookstoves. This paper has not gone through IFPRI's standard peer-review procedure. The opinions expressed here belong to the authors, and do not necessarily reflect those of PIM, IFPRI, or CGIAR, BMZ, LUNAR or the MaSSP. 


\section{INTRODUCTION}

Food, energy, and water are essential aspects of life, yet many do not have adequate access to these resources. Estimations are that 842 million people suffer from chronic hunger (FAO, IFAD, and WFP 2013); 768 million do not have access to improved drinking water sources (WHO and UNICEF 2013); and approximately 3 billion people cook their food and warm themselves on open fires fueled by wood, straw, charcoal, coal, or dung, which are very inefficient and damaging to health (WHO and UNDP 2009). Projections indicate that food, energy, and water insecurity will increase in the coming decades (UNEP 2007; Meade and Rosen 2013). Analyzing food, energy, and water security issues simultaneously is critical given their interconnections. The term nexus has been increasingly applied to describe opportunities and challenges related to interlinkages between food, energy, and water. For example, in 2012 Secretary General of the United Nations Ban Ki-moon spoke of the food-energy-water security nexus (FEW nexus) and the importance of linking and pursuing the three sectors together (UN 2012). One reason for the increasing use and awareness of the FEW nexus is the greater impacts on food, energy, and water resources caused by increased population, income, middle class, urbanization, globalization, land degradation, and climate change (Hoff 2011). Although the FEW nexus is far from novel, it may be useful in focusing capacity and spreading awareness (Muller 2013). Its application may be greatly expanded if it is integrated into the Sustainable Development Goals, the follow-up to the Millennium Development Goals.

This paper aims to more clearly define the FEW nexus, conceptualize its synergies and trade-offs, and analyze why nexus interventions are not more widely applied; elaborate on case studies of nexus policies in Malawi and Mozambique and provide a framework for how to analyze nexus policies through household-level and economywide models; and analyze secondary data through a nexus perspective in Malawi and Mozambique. We focus on how the FEW nexus applies to rural areas in developing countries because the majority of people living in extreme poverty are in rural areas with agriculture as their main source of livelihood (IFAD and UNEP 2013). Moreover, given that the highest proportion of people who suffer from hunger, rely on rainfed agriculture, and use unclean cooking facilities are in Africa south of the Sahara (SSA) (FAO, IFAD, and WFP 2013; IWMI, undated), the case studies focus on this region.

\section{Defining the FEW Nexus}

Despite the increasing use of the term nexus being applied to food, water, and energy security, few definitions of the FEW nexus are concrete. A clear definition of the FEW nexus would help to enable stakeholders, such as policymakers, the private sector, practitioners, and academics, to communicate more effectively. This, in turn, would allow stakeholders to better develop nexus interventions and analyze outcomes. Previous definitions of the nexus include "how and where these three systems intersect" (Hanlon et al. 2013, 7); "the complex relationships and tradeoffs between these tightly linked systems" (Gerholdt and Pandya 2009, 2); and "a 'system' governed by complexity and feedback mechanisms that cannot be reconciled by studying each component separately" (Savic 2012, 22). In our opinion, these definitions are not specific enough to allow the FEW nexus to be pragmatically analyzed and applied. The definition we propose is as follows: The food-energy-water security nexus encompasses synergies and trade-offs between food, energy, and water security that are impacted by endogenous and exogenous drivers and cannot be captured if these sectors are analyzed in isolation.

Figure 1.1 contains the conceptual framework of the FEW nexus. As shown, food, energy, and water security entails trade-offs and synergies. In other words, increasing the security of one sector may negatively or positively affect that of another sector; for example-

- Water for energy: Water is needed for cooling, extracting fuels, and producing energy.

- Energy for water: Energy is needed to supply, treat, collect, pump, and desalinate water.

- Water for food: Enhanced water efficiency can improve food security through more harvests per year, higher yields, and improved diversification (Burney et al. 2010). 
Irrigation may create labor opportunities, which enhance food accessibility through higher off-farm income (Asayehegn 2012). Water-related diseases are the main cause of food insecurity among children by decreasing food utilization.

- Food for water: Increased pressure on food systems increases water demands along the supply chain.

- Energy for food: Energy is inherent in food production, supply, and preparation, such as through fertilizers, mechanization, and fuels.

- Food for energy: Food crops can be used to produce biofuels.

Figure 1.1 Conceptual framework of the FEW nexus

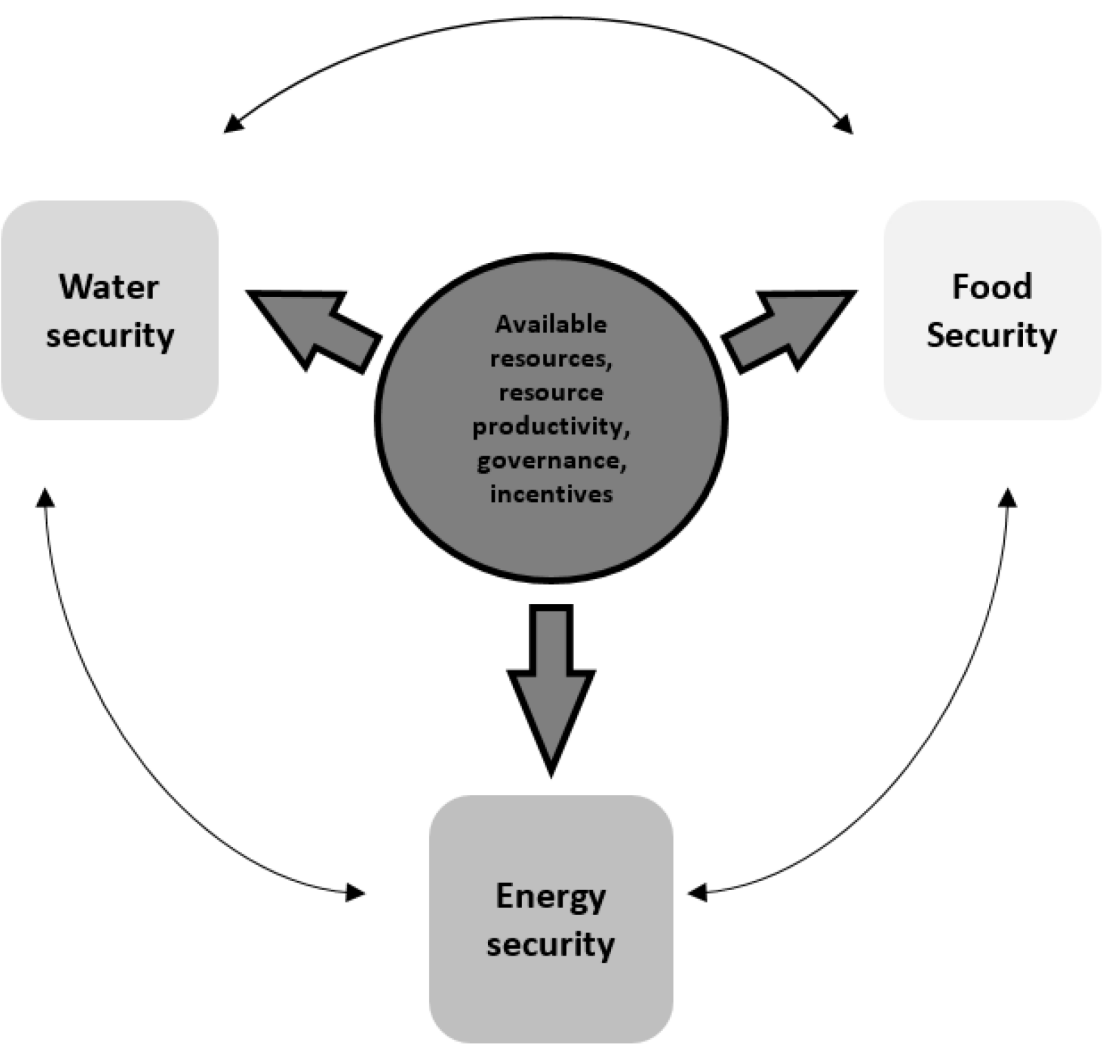

Source: Authors' creation.

Food, energy, and water security are affected by indirect and direct parameters, which are both outcomes and effects of the nexus. Drivers include institutions and governance systems (Nkonya, Pender, and Kato 2008b), infrastructure (Boyd and Slaymaker 2000), demographics, technology like molecular biology, climate change, and natural resources (Ringler, Bhaduri, and Lawford 2013). Endogenous drivers always directly affect at least food, water, or energy security, whereas exogenous drivers can be distinguished as either direct or indirect. The distinction between direct and indirect effects is important: a direct effect occurs if a policy through no other mechanism has an effect on water, energy, or food security (or any combination), whereas an indirect effect is triggered by a complementary system other than energy, food, or water, such as through spillover effects or other mechanisms like markets and prices. For example, rainfall is considered to be a direct exogenous driver, whereas exchange rates are an indirect exogenous driver because they affect several macroeconomic systems and through these system changes they eventually affect water, energy, or food security through changes in the ability to import 
technology or export food, for example. An example of an exogenous drivers is good governance in natural resource management, which is a driver embedded within the nexus and may impact water security. Yet, decreased water security may affect good governance by increasing pressure on its rules and regulations. Thus, because governance is a driver directly affecting water security and is also affected through feedback and feed-forward loops, ${ }^{1}$ it is an endogenous system variable. In fact, many synergies and trade-offs among water, energy, and food security are endogenous drivers causing the nexus to react or adapt. Moreover, the nexus itself affects drivers through feedback and feed-forward loops.

Other nexuses are related to the FEW nexus. Some entail a different ordering, such as the waterenergy-food security nexus (Hoff 2011; Smakhtin and Ringler 2013), or incorporate other components into the nexus, such as the food-energy nexus and ecosystems (UNESCO 1987), the soil-water-waste nexus (Lal 2013), and the water-food-trade nexus (McCalla 1997). In addition, the FEW nexus has been expanded to explicitly include more concepts, such as the water-energy-land-food nexus (Ringler, Bhaduri, and Lawford 2013), the water-energy-food-climate nexus (World Economic Forum 2011), and the water-energy-food/feed/fiber/fuel-climate change nexus (World Business Council for Sustainable Development, undated).

This leads into two opposing criticisms: that the nexus already entails too much and that it does not include enough. We believe that these criticisms can be mollified by avoiding a "throw everything into the kitchen sink" approach. Instead of expanding the FEW nexus to explicitly include related components, these aspects should be embedded in the FEW nexus and elaborated upon depending on users' needs. For example, soil is inherent in the nexus it is affected by and affects all three components of the nexus. Figure 1.1 excludes long-term developments such as climate change, urbanization, and population growth, which affect the FEW nexus and which, in turn, may also be affected by the nexus. These trends are excluded for analytical purposes since everything can be considered an endogenous driver of the FEW nexus in the long term. We therefore adopt a shorter time horizon of 10-20 years for the remainder of this paper and propose this time period for analytical purposes and to keep policymakers focused. The inclusion of these factors may, in part, result from the recognition of the endogeneity of all systems in the long run. The shorter time horizon would result in excluding climate change and demographic changes, for example, from the nexus. Applying the nexus by geographical region or along an urban-rural divide may further enable stakeholders to focus their application of the FEW nexus. For example, Ursula Eid, co-chair of the Bonn 2011 Nexus Conference, recommends nexus nuclei for each region. We support this initiative yet do not elaborate on this idea further since it does not contribute conceptually to this paper. Below, we build upon the definition of a FEW nexus by defining a nexus intervention.

\section{Definition of a Nexus Intervention}

Given that the importance of the FEW nexus concept is to enable stakeholders to find tools, interventions, and research methods to improve and better understand food, energy, and water security when considering interactions and trade-offs among these goals, it is important to clearly define a FEW nexus intervention (hereafter, "nexus intervention"). Thus far, no definition of what a nexus intervention entails has been explicit, and attempts have been vague. For example, a report written from the Bonn 2011 Nexus Conference states that a nexus approach "integrates management and governance across sectors and scales. Conventional policy and decision-making in 'silos' therefore needs to give way to an approach that reduces trade-offs and builds synergies across sectors - a nexus approach" (Hoff 2011, 7). Although it is evident that a nexus intervention needs to affect the different sectors within the nexus, it is unclear if all three sectors need to be affected by an intervention and if these affects are direct or indirect. We propose the following definition: To be considered a nexus intervention, the intervention must impact food, energy, and water security, of which at least one impact must be direct. If the distinction between

\footnotetext{
${ }^{1}$ The term feed-forward loops is mainly applied to the genetic literature (for example, Murugan 2012). Here, a feed-forward loop is signified as meaning that the driver can affect future nexus adaptations.
} 
indirect and direct effects is removed from the definition, then nearly any policy could be considered a nexus policy, including exchange rate policies, which indirectly affect all three sectors.

Table 1.1 shows examples of nexus interventions and the direct and indirect effects they may have on water, energy, and food security. The interventions shown affect endogenous drivers such as price and availability, thereby creating direct effects on water, energy, and food security. Exogenous policy variables, such as exchange rates or improving general trust in society through better institutions and legislation, are excluded. Food, energy, and water security are multidimensional and exist both at the macro- (global, regional, and national) and micro- (household or individual) levels. The availability of food, water, and energy through macrolevel policies are essential for improving their access at the microlevel. However, cases may exist in which a policy that has a positive effect on the macro dimension could negatively affect the micro dimension. For example, the promotion of biofuel production could increase macrolevel energy security; however, if forests need to be cleared to make land available for biofuel production, the rural population will need to walk even further to collect sufficient firewood, thus decreasing their microlevel energy security. Therefore, exploring both macro- and microlevel aspects of food, energy, and water security is pertinent not only separately but simultaneously as well.

\section{Table 1.1 Examples of nexus interventions}

\begin{tabular}{|c|c|c|c|}
\hline Intervention & Water security & Energy security & Food security \\
\hline More efficient irrigation & $\begin{array}{l}\text { Direct: Improved } \\
\text { water use efficiency. }\end{array}$ & $\begin{array}{l}\text { Direct: More energy } \\
\text { required for irrigation, } \\
\text { such as from diesel for } \\
\text { motor pumps. }\end{array}$ & $\begin{array}{l}\text { Direct: May improve yields. } \\
\text { Indirect: Employment } \\
\text { opportunities from the } \\
\text { irrigation system may improve } \\
\text { food access. }\end{array}$ \\
\hline $\begin{array}{l}\text { Improved soil conservation } \\
\text { techniques (such as } \\
\text { mulching, nitrogen-fixing } \\
\text { leguminous trees, } \\
\text { intercropping fruit trees) }\end{array}$ & $\begin{array}{l}\text { Direct: May improve } \\
\text { water retention of } \\
\text { soils. }\end{array}$ & $\begin{array}{l}\text { Direct: May decrease } \\
\text { use of fertilizers and } \\
\text { fossil fuels. In case } \\
\text { machinery is needed for } \\
\text { land preparation, fossil } \\
\text { fuel demand may } \\
\text { increase. }\end{array}$ & $\begin{array}{l}\text { Direct: Yields may improve, } \\
\text { especially in the long run, } \\
\text { from improved soil quality. } \\
\text { Food security may improve if } \\
\text { the availability of nutritious } \\
\text { foods or yields increases. }\end{array}$ \\
\hline Biofuel production & $\begin{array}{l}\text { Direct: Water is } \\
\text { required to produce } \\
\text { crops for biofuels } \\
\text { and to produce } \\
\text { biofuels. }\end{array}$ & $\begin{array}{l}\text { Direct: Energy security } \\
\text { is enhanced through } \\
\text { less dependence on } \\
\text { fossil fuels. }\end{array}$ & $\begin{array}{l}\text { Direct: The production of } \\
\text { bioenergy from food crops } \\
\text { may reduce food availability. } \\
\text { Indirect: Food accessibility } \\
\text { may improve if income gains } \\
\text { offset reductions in food } \\
\text { production. }\end{array}$ \\
\hline Fertilizer subsidy & $\begin{array}{l}\text { Direct: Runoff from } \\
\text { fertilizer may } \\
\text { negatively impact } \\
\text { water resources. }\end{array}$ & $\begin{array}{l}\text { Direct: May increase } \\
\text { demand and use of } \\
\text { fertilizers and fossil } \\
\text { fuels. }\end{array}$ & $\begin{array}{l}\text { Direct: Improved yields } \\
\text { increase food availability. May } \\
\text { affect dietary diversity if it } \\
\text { encourages farmers to plant } \\
\text { different crops. } \\
\text { Indirect: Food access may } \\
\text { improve if farmers have more } \\
\text { leftover resources. }\end{array}$ \\
\hline $\begin{array}{l}\text { Energy-efficient } \\
\text { cookstoves }\end{array}$ & $\begin{array}{l}\text { Direct: If less wood } \\
\text { is used, } \\
\text { deforestation } \\
\text { decreases, which } \\
\text { increases water } \\
\text { retention of soils. }\end{array}$ & $\begin{array}{l}\text { Direct: If the cookstove } \\
\text { is used less, then less } \\
\text { energy is needed to } \\
\text { cook. }\end{array}$ & $\begin{array}{l}\text { Indirect: May occur through } \\
\text { changes in cooking habits } \\
\text { and in time-labor allocation. }\end{array}$ \\
\hline
\end{tabular}

Source: Authors. 


\section{Why Is the Nexus Approach Difficult to Adopt and Apply?}

After an extensive literature review, we were surprised to identify only two policy interventions that were considered nexus interventions ex ante. This is a result of the nexus approach being difficult for policymakers, organizations, the private sector, researchers, and other stakeholders to adopt and apply. One reason for this is that the FEW nexus depends upon and impacts common pool resources, ${ }^{2}$ such as groundwater basins and forests, which can be difficult to manage (Ostrom et al. 1999; Hardin 1968). The matter is further complicated by the interlinked nature of these systems, which yields their management more difficult (Ostrom et al. 1999). Moreover, food, energy, and water security are global public goods because of the global concern about the nexus and an interdependence of regions related to the nexus (Savic 2012). Complicating matters further are self-sovereignty and security issues related to water, energy, and food as well as a lack of an enforcing mechanism at the global level to ensure that water, energy, and food resources are being protected (Savic 2012). In the absence of a silver bullet property regime to manage fairly and sustainably common pool resources (Ostrom 1999; Ostrom et al. 1999), further research is needed on what type of institutions, technologies, and policies work best in different settings with respect to sustainably and effectively managing the FEW nexus, so that policymakers and other stakeholders can be better informed.

A mantra of the nexus approach is to abandon the silo approach and adopt a systems approach (Hanlon et al. 2013; IGEL 2013), requiring an interdisciplinary approach. According to Hardin, "The more specialties we try to stitch together, the greater are our opportunities to make mistakes - and the more numerous are our willing critics" $(1968$, p. 683). For policymakers, the nexus approach requires that different ministries work together, yet they have little incentive to do so because of barriers to collaboration, which Hardy, Turrell, and Wistow (1992) identify as structural, procedural, financial, and professional as well as based on status and legitimacy concerns. For example, budgets, reporting, and accountability are often specific to individual ministries. Disadvantages of agencies working separately, so-called pitfalls of individualism (Huxham and MacDonald 1992) are repetition, omission, divergence, and counterproduction. Interagency cooperation is theorized to be the result of either rationality (efficiency) (Challis et al. 1988) or altruism (Booth 1988) for the community (Hudson et al. 1999). Recommendations for encouraging cooperation among different agencies include to develop and agree on common goals, share responsibilities to obtain these goals, and work together to achieve these goals (Brunner 1991 in Murk 1994). ${ }^{3}$ Without a reorganization of the government budget, such as to encourage interministry policies, nexus policies are difficult to adopt because policymakers are unsure if their ministry is responsible for a nexus policy that cuts across different sectors. Other options for increasing interaction across ministries include having a lead department take responsibility, having a nonparticipating minister be a coordinator, and having ministers take collective responsibility (Wilkins 2002). Key is that horizontal accountability measures should replace vertical ones (Ryan and Walsh 2004). Cooperation among researchers across disciplines is also challenging because of the lack of an articulated framework, the time required for group processes, misconceptions that disciplines may have of one another, language barriers, and publishing concerns (Campbell 2005; Picket, Burch, and Grove 1999; Parker 1994; Redclift 1998). The private sector can also help in improving water, energy, and food security, but they too need incentives. Another incentive is to work on a common problem (Picket, Burch, and Grove 1999). For the FEW nexus, the common problem all three sectors face is increasing pressure on natural resources. However, stakeholders need evidence.

This paper focuses on the application of the FEW nexus in Malawi and Mozambique. Malawi's long-term and overarching policy strategy is Vision 2020, which aims to transform the country to a middle-income economy that is democratically mature and self-reliant with equal opportunity by 2020 (GOM 1998). The development strategy in Vision 2020 was enacted with nine priority areas. The strategic priorities most relevant to the FEW nexus are agriculture and food security, which aims to

\footnotetext{
${ }^{2}$ Common pool resources are resource systems, regardless of the property rights involved (Ostrom et al. 1999).

${ }^{3}$ For further reading, we recommend Hudson et al. (1999) for theoretical and conceptual explanations on interagency cooperation and a report by the United States Government Accountability Office (2014) for practical guidelines.
} 
enhance food security by increasing and diversifying agricultural production through improving extension services, agricultural markets, and national food storage capacity (GOM 1998); energy; integrated rural development; Irrigation and water development; and natural resources and environmental management. Mozambique's long-term development strategy is described in the Agenda 2025. Following the proposed strategies, the government formulated the Five-year Program of Government for 2010 to 2014. The development of the agricultural sector is a priority area, especially increasing productivity, supporting small- and medium-scale irrigation, developing roads and markets, and managing the available natural resources sustainably (AfDB 2011).

In the following section, we provide an overview of policies that can be considered FEW nexus interventions in Malawi and Mozambique. Section 3 specifies how macrolevel analyses on nexus interventions can be analyzed using ex ante analysis through various methods. At the end of the section a macrolevel model of small-scale irrigation suitability is examined. Section 4 specifies how microlevel analyses on nexus interventions can be examined and contains an analysis of food, energy, and water securities as well as the adoption of FEW nexus technologies based on secondary data from Malawi and Mozambique. Throughout the paper, research gaps are identified and opportunities for future research and policy options are explored. The final section concludes by summarizing the main findings and offering steps forward for future research and applications of the FEW nexus approach. 


\section{NEXUS INTERVENTIONS IN MALAWI AND MOZAMBIQUE}

Nexus interventions that have been promoted as such in the true sense of the term are rare in developing countries, especially in SSA. Two examples in the literature are an irrigation and electricity project in Gujarat, India, and a payment for ecosystem services scheme in Kenya (Hoff 2011). This section concentrates on interventions that can be considered nexus interventions in Malawi and Mozambique but were not promoted as such. In particular, through a nexus approach we examine a fertilizer subsidy program, irrigation, hydroenergy, biofuels, agroforestry, and improved cookstoves in Malawi and Mozambique. We discuss their potential micro- and macrolevel impacts, highlighting previous studies and research gaps related to analyzing the impacts of these policies through a nexus perspective.

\section{Malawi Food Security Policies: Farm Input Subsidy Program}

Malawi's Farm Input Subsidy Program (FISP) is a nexus intervention that has shaped the country's development and agricultural policy the most. This national program began in 2005 after the end of several maize input subsidy programs from the 1990s and severe droughts early in the following decade (Dorward et al. 2008). Since its inception, its expenditures have accounted for more than 60 percent of Malawi's agricultural budget (see Table 2.1). FISP aims to enhance food security through improving agricultural productivity by increasing maize production, promoting household food security, and increasing income (Lunduka, Ricker-Gilbert, and Fisher 2013) by decreasing the costs of fertilizer and improved maize seed for poor smallholder farmers (Arndt, Pauw, and Thurlow 2013). The program targets almost half of all Malawian farmers, but targeting has been unsuccessful in many cases (for example, Dorward et al. 2008; Houssou and Zeller 2011). Farmers who qualify are supposed to receive two 50-kilogram bags of fertilizer and in some cases modern maize or soybean seeds. Although per capita food production has increased significantly since FISP began (see Figure 2.1), per capita protein and energy requirements are on or below the borderline (Figure 2.2 and Figure 2.3) - and whether FISP is responsible for these increases has been questioned.

Table 2.1 FISP investment

\begin{tabular}{lllllll}
\hline Cropping year & $\mathbf{2 0 0 5 / 2 0 0 6}$ & $\mathbf{2 0 0 6 / 2 0 0 7}$ & $\mathbf{2 0 0 7 / 2 0 0 8}$ & $\mathbf{2 0 0 8 / 2 0 0 9}$ & $\mathbf{2 0 0 9 / 2 0 1 0}$ & $\mathbf{2 0 1 0 / 2 0 1 1}$ \\
\hline $\begin{array}{l}\text { Total fertilizer subsidized } \\
\text { ('000 MT) }\end{array}$ & 131.39 & 179.00 & 216.56 & 202.28 & 160.00 & 160.00 \\
$\begin{array}{l}\text { Total maize seed } \\
\text { subsidized ('000 MT) }\end{array}$ & N/A & 4.52 & 5.54 & 5.37 & 8.65 & 8.00 \\
$\begin{array}{l}\text { Total legume seed } \\
\text { subsidized ('000 MT) }\end{array}$ & 0.00 & 0.00 & 0.02 & N/A & 1.55 & 1.60 \\
$\begin{array}{l}\text { Fertilizer subsidy rate } \\
\text { paid by government (\%) }\end{array}$ & 64 & 72 & 79 & 91 & 95 & 90 \\
$\begin{array}{l}\text { Total program cost (US\$ } \\
\text { million) }\end{array}$ & 55.71 & 88.69 & 114.62 & 274.92 & 114.60 & 127.47 \\
$\begin{array}{l}\text { Total cost as \% } \\
\text { agricultural budget }\end{array}$ & N/A & 61 & 61 & 74 & 62 & 61 \\
$\begin{array}{l}\text { Total cost as \% of } \\
\text { national budget }\end{array}$ & 5.6 & 8.4 & 8.9 & 16.2 & 8.2 & 6.5
\end{tabular}

Source: Lunduka, Ricker-Gilbert, and Fisher (2013).

Note: $\quad$ MT $=$ metric tons. 
Figure 2.1 Per capita production in Malawi, Mozambique, and Africa south of the Sahara regions

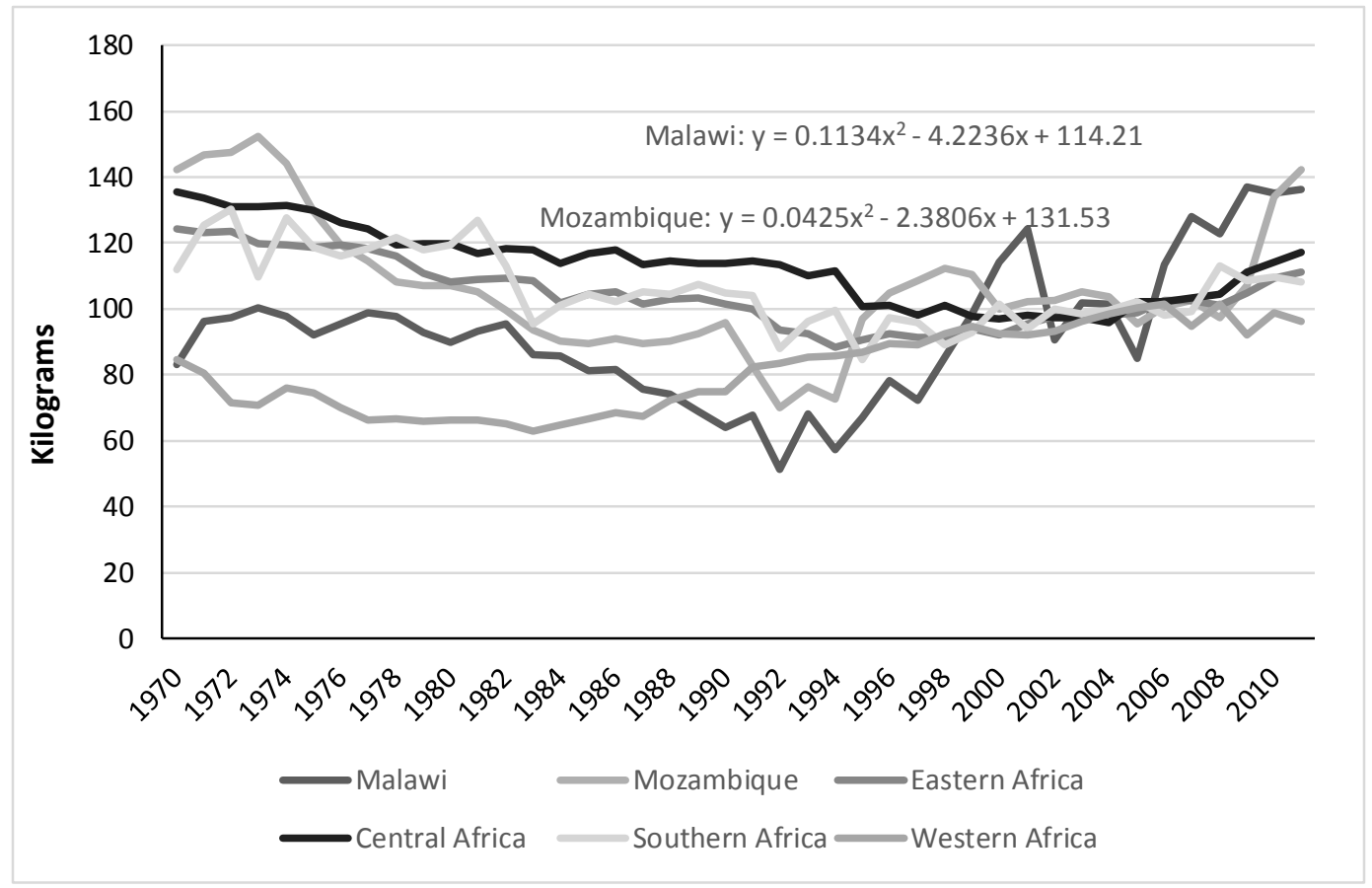

Source: FAOSTAT (FAO 2015).

Figure 2.2 Daily protein supply in Malawi, Mozambique, and Southern Africa

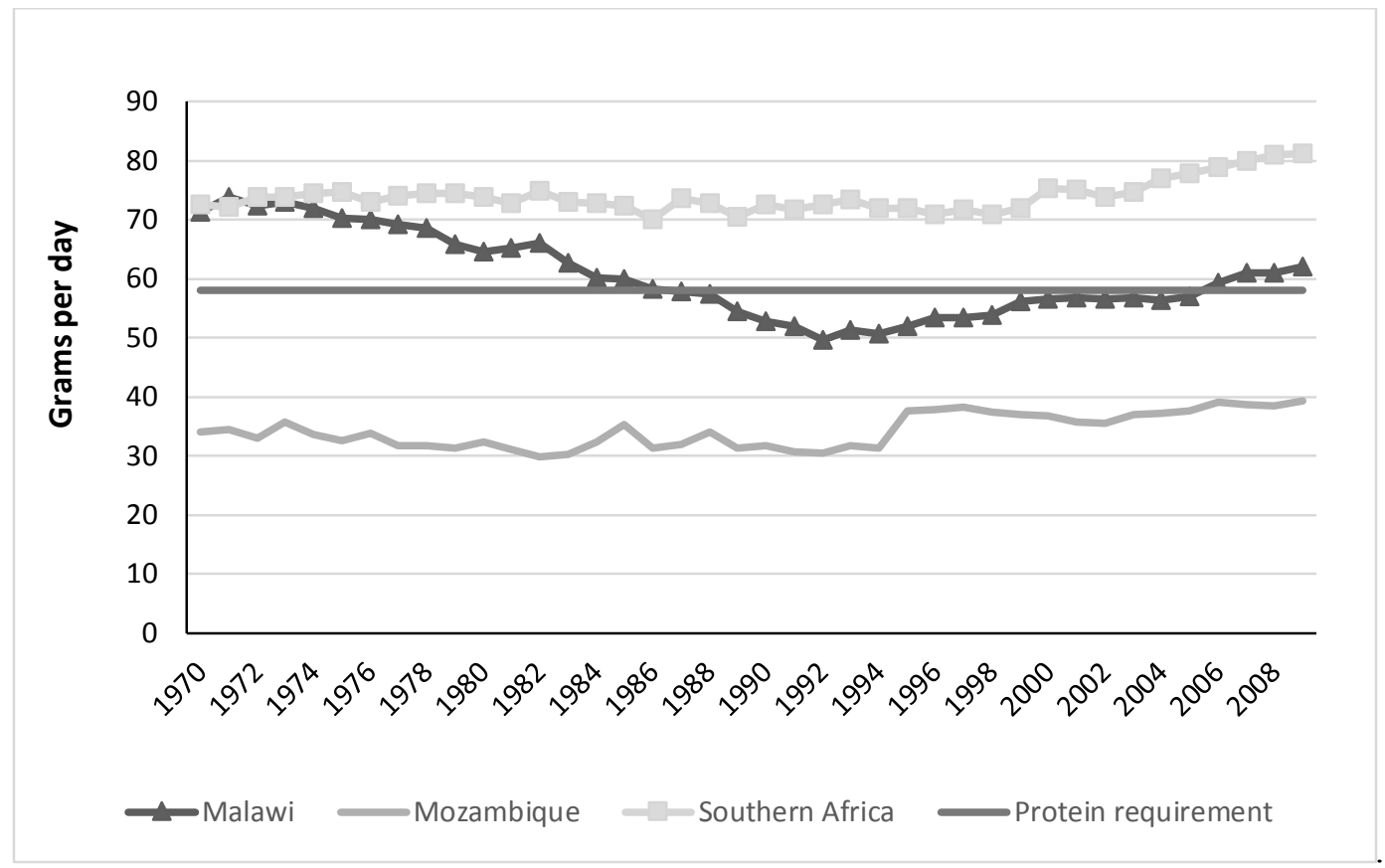

Source: FAOSTAT (2015).

Notes: Protein requirement per capita per day for $70 \mathrm{~kg}$ adult. Recommended daily protein requirement $=0.83 \mathrm{~g} / \mathrm{kg}$ of body weight (FAO, WHO, and UNU Committee 1985). 
Figure 2.3 Energy supply in Malawi, Mozambique, and Southern Africa

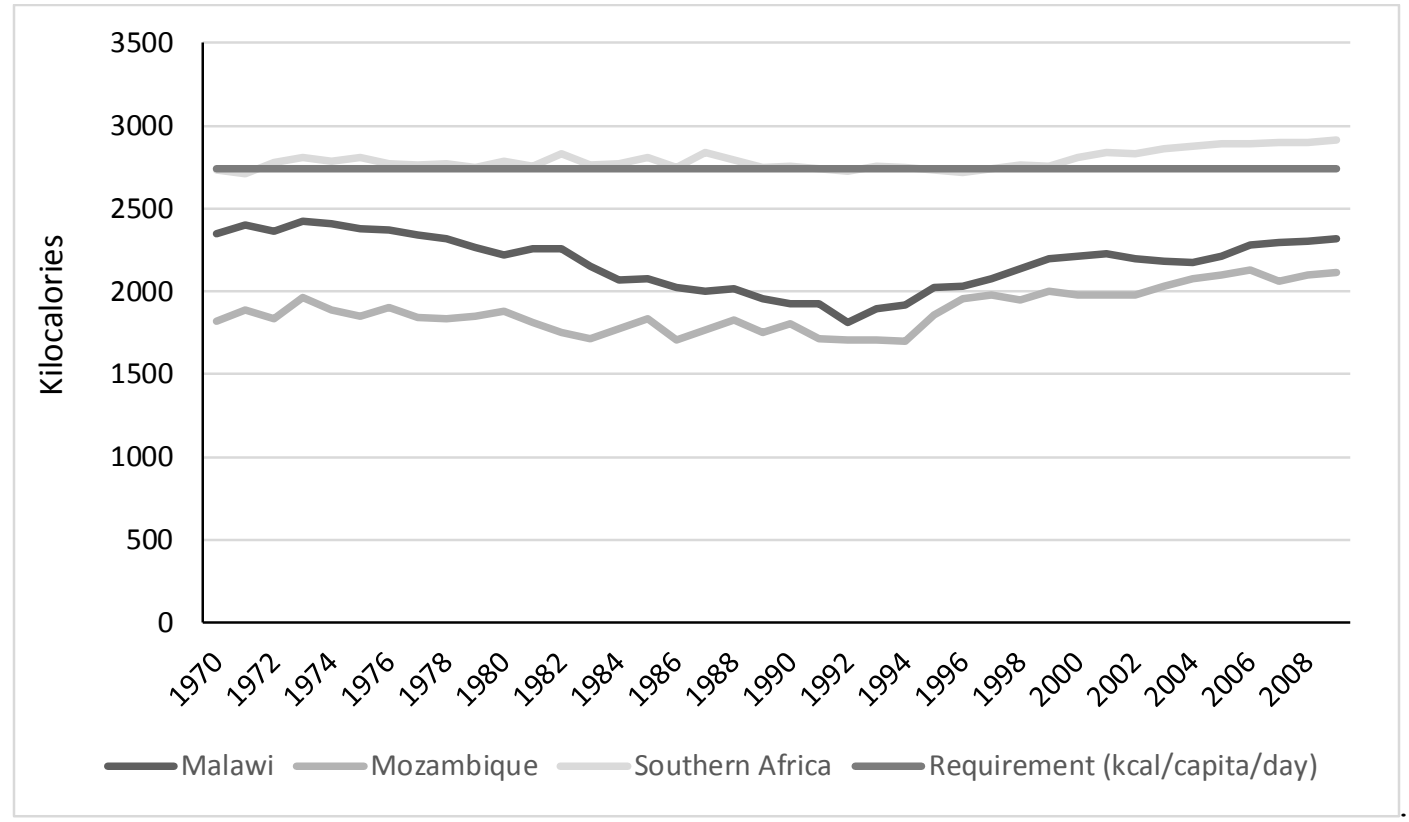

Source: Energy supply is calculated using FAOSTAT (FAO 2015).

Note: Energy requirement calculated assuming an average basal metabolism rate (BMR) of 1.75, which is the amount of energy expenditure for basal metabolism per day (FAO, WHO, and UNU Committee 2001).

Before proceeding with previous studies' findings on the impact of FISP on food, water, and energy security, we discuss why this agricultural input subsidy program can be considered a nexus intervention. A possible direct impact of input subsidies on food security is apparent through higher national food production, that is, macrolevel food security, and better access to and utilization of food from higher subsistence maize production and disposable income, that is, microlevel food security. Direct effects on water and energy security are less obvious. On the one hand, an increase in food production is likely to entail a higher demand for water and thus decrease water availability indirectly. On the other hand, given the definition of water security by UN-Water, which emphasizes "acceptable quality water" (UN Water 2013) as a dimension of water security, fertilizer subsidies may directly influence water security. Mineral and chemical fertilizer can be washed away by rain into rivers and lakes and cause eutrophication, which drastically increases algae. Moreover, extensive use of fertilizer can pollute ground and drinking water (Ongley 1996). Therefore, FISP may have direct and indirect impacts on water security. A direct relationship between energy security and fertilizer exists since the production of ammonia and nitrogen fertilizer requires energy in the form of natural gas. Since Malawi is a net importer of fertilizer, the production of nitrogen does not directly affect energy security in Malawi; however, if one analyzes the potential effects of FISP on energy security at the national level, one can find indirect linkages through higher agricultural output, potentially leading to economic growth and higher energy demand.

Many studies analyze whether FISP has impacted food security, though few examine energy or water security (Table 2.2 contains a summary of these studies). Within the handful of studies examining the impact of FISP on energy security is evidence of both positive and negative impacts (for example, Chibwana, Jumbe, and Shively (2012) for deforestation). Although no studies explicitly examine effects of FISP on eutrophication of rivers and lakes, eutrophication is likely to have increased in recent years from increased fertilizer use and other causes such as deforestation and soil erosion. However, a recent study did not find that increased fertilizer use through FISP led to alarming nitrate levels in Malawi's groundwater (Von Hellens 2013). In addition, Hecky, Bootsma, and Kingdon (2003) and Otu et al. (2011) find evidence of early stages of eutrophication in Lake Malawi before 2003, two years before FISP began. 
In terms of the impact of FISP on food security, several studies find large increases in maize output and thus in food availability at macro- and microlevels (Douillet, Pauw, and Thurlow 2012; Arndt, Pauw, and Thurlow 2013), yet favorable weather conditions are likely to have made significant contributions to these improvements (for example, Dorward et al. 2008). Moreover, general equilibrium simulations find substantial improvements in food access and utilization through improvements in calorie and nutrient deficiencies (Ecker, Breisinger, and Pauw 2011). This may stem from findings that improved land productivity for maize resulting from FISP led to land reallocation and higher crop diversification (Douillet, Pauw, and Thurlow 2012; Arndt, Pauw, and Thurlow 2013). Other indirect effects on food security may result from the crowding out of private agricultural input markets caused by FISP (Mason and Ricker-Gilbert 2013; Ricker-Gilbert, Jayne, and Chirwa 2011).

Table 2.2 Impact of fertilizer subsidies in Malawi

\begin{tabular}{llll}
\hline Study & $\begin{array}{l}\text { Geographical } \\
\text { focus }\end{array}$ & $\begin{array}{l}\text { Outcome(s) } \\
\text { measured }\end{array}$ & Key finding(s) \\
\hline $\begin{array}{l}\text { Chibwana et al. } \\
(2014)\end{array}$ & $\begin{array}{l}\text { Kasungu and Machinga } \\
\text { districts }\end{array}$ & Maize yields & $\begin{array}{l}\text { Maize yield was positively associated with } \\
\text { receipt of subsidized fertilizer. }\end{array}$
\end{tabular}

Chibwana, Fisher, Kasungu and Machinga FISP coupon receipt and and Shively (2012) districts crop allocation

Chibwana, Jumbe, Chimaliro and Liwonde Forest clearing and Shively (2012) Forest reserves in Kasungu and Machinga districts

Chirwa (2010)

Nationally representative household survey data

Real per capita annual expenditure

Chirwa et al. Nationally (2011) representative household survey data

Probability of commercial and/or subsidized fertilizer application

Fisher and Kandiwa (2013)

Nationally representative household survey data

Holden and Lunduka (2010)

Holden and Lunduka (2012a)
Kasungu, Lilongwe, Maize area share, tree Machinga, Zomba, planting, and forest Chiradzulu, and Thyolo clearing districts

Same as above

FISP coupon receipt
Monetary value of the FISP coupon redeemed for modern maize and adoption by male and female farmers
Asset-poor and female-headed households were less likely to receive FISP coupons; receipt of a FISP coupon was associated with an increase in the share of land planted with maize.

Households that received FISP coupons had lower forest clearing than those that did not receive the coupon; indirect negative forest effects arose due to the use of trees to construct tobacco drying sheds.

Annual per capita expenditure of households receiving full fertilizer coupon package increased by $8.2 \%$ compared with nonrecipients.

No significant difference in fertilizer application by gender of the plot manager for households that received subsidized fertilizer and did not have access to other fertilizer.

Female household heads had a higher value of redeemed coupons than male household heads; FISP did not seem to influence the adoption of modern maize by gender, but simulations suggest it could reduce the adoption gap by gender substantially if the poorest households were targeted.

Better access to input subsidies over time was associated with maize intensification and smaller maize area planted.

FISP did not target the poor; the program enhanced maize production and food security. 
Table 2.2 Continued

\begin{tabular}{|c|c|c|c|}
\hline Study & $\begin{array}{l}\text { Geographical } \\
\text { focus }\end{array}$ & $\begin{array}{l}\text { Outcome(s) } \\
\text { measured }\end{array}$ & Key finding(s) \\
\hline $\begin{array}{l}\text { Holden and } \\
\text { Lunduka (2012b) }\end{array}$ & Same as above & $\begin{array}{l}\text { Probability and intensity } \\
\text { of organic manure use }\end{array}$ & $\begin{array}{l}\text { Access to subsidized inputs slightly } \\
\text { crowded out manure use. }\end{array}$ \\
\hline $\begin{array}{l}\text { Mason and Ricker- } \\
\text { Gilbert (2013) }\end{array}$ & $\begin{array}{l}\text { Malawi and Zambia- } \\
\text { nationally representative } \\
\text { household data }\end{array}$ & $\begin{array}{l}\text { Crowding out of } \\
\text { commercial seed by } \\
\text { subsidized seed and } \\
\text { fertilizer }\end{array}$ & $\begin{array}{l}1.00 \mathrm{~kg} \text { of subsidized seed crowded out } \\
0.56 \mathrm{~kg} \text { of commercial seed. }\end{array}$ \\
\hline $\begin{array}{l}\text { Ricker-Gilbert and } \\
\text { Jayne (2011) }\end{array}$ & $\begin{array}{l}\text { Malawi-nationally } \\
\text { representative } \\
\text { household survey data }\end{array}$ & $\begin{array}{l}\text { Maize production, net } \\
\text { value of crop production, } \\
\text { income asset wealth }\end{array}$ & $\begin{array}{l}\text { Small positive effect from subsidized } \\
\text { fertilizer on maize production in current year } \\
\text { and overtime. No significant effect on asset } \\
\text { wealth from the subsidy. }\end{array}$ \\
\hline $\begin{array}{l}\text { Ricker-Gilbert and } \\
\text { Jayne (2012) }\end{array}$ & As above & $\begin{array}{l}\text { Maize production and } \\
\text { value of output }\end{array}$ & $\begin{array}{l}\text { Returns to subsidized fertilizer were much } \\
\text { higher for those at the top of the maize } \\
\text { production distribution. }\end{array}$ \\
\hline $\begin{array}{l}\text { Ricker-Gilbert, } \\
\text { Jayne, and Chinwa } \\
\text { (2011) }\end{array}$ & As above & $\begin{array}{l}\text { Farmer demand for } \\
\text { commercial fertilizer }\end{array}$ & $\begin{array}{l}\text { Additional } 1.00 \mathrm{~kg} \text { of subsidized fertilizer } \\
\text { crowded out } 0.22 \mathrm{~kg} \text { of commercial fertilizer. }\end{array}$ \\
\hline
\end{tabular}

Source: Extracted from Lunduka, Ricker-Gilbert, and Fisher (2013).

In addition to these studies, others examine the impact of FISP on poverty. Douillet, Pauw, and Thurlow (2012) simulate economywide output and poverty effects of FISP. They find that although poverty is strongly related to food access, it cannot be confirmed that FISP will lead to pronounced poverty reductions. One explanation is the program's leakage to nonpoor households, and another is that net maize sellers' disposable income is negatively affected by lower maize prices. In contrast, computable general equilibrium (CGE) simulations by Arndt, Pauw, and Thurlow (2013) show that in 2006/2007, FISP led to a decline in the national poverty rate by 2.7 percentage points. These contrasting findings may result from the authors' applying a somewhat more sophisticated model with a poverty module that allows for the simulation of more pronounced poverty effects in different population segments. In addition, they find a large expansion of agricultural gross domestic product (GDP) due to increased agricultural productivity from FISP, which is very likely to have large effects on macrolevel energy security through increased demand for energy.

\section{Mozambican Food Security Policies}

Mozambique does not have a policy similar to Malawi's FISP. Mozambique's agricultural sector suffers from low yields, low application of inputs, and poor infrastructure. In fact, its yields are among the lowest in SSA (FAO and CIMMYT 1997). For example, for the main staple crops cassava and maize, yields range from 4.0 to 5.0 tons/hectare and from 0.4 to 1.3 tons/hectare, respectively (Gemo 2011). Less than half of smallholder farmers are able to produce enough output for their household needs (Tschirley and Abdula 2007), and the country relies heavily on food imports. Reasons for low yields include underdeveloped extension services (Mozambique, MINAG 2013; Thurlow 2012) and limited access to inputs (Uaiene 2008; Tschirley and Benica 2001; Heltberg and Tarp 2002). For example, in 2007 only 4 percent of smallholder farmers applied pesticides and 10 percent used improved maize variety seeds (Mutondo, Tostão, and Zavale 2009). Table 2.3 shows that fertilizer use in Mozambique is very low compared with other SSA countries. This average masks its varied application across crops and regions: Fertilizer is applied mostly to horticultural crops near cities and to contract crops like tobacco and sugarcane, whereas its use for staple foods is lower (Gemo 2011; ICRISAT 2011). Farmers are unable to afford agricultural inputs (Mucavele 2009; Mozambique, MINAG 2010) because of high world market 
prices and transaction costs resulting from a weak distribution network, which makes inputs in many regions inaccessible (ICRISAT 2011; Gemo 2011). In fact, the low distribution of inputs coupled with the ability to convert abandoned land into agricultural production hinders the development of input markets, since it is cheaper to convert land than to buy fertilizer or improved seeds (Benson, Woldeyohannes, and Mogues 2013). Mozambique's heavy reliance on food imports is also a consequence of geography and poor infrastructure, which makes it economically unfeasible to supply the southern regions from the northern surplus regions (Mucavele 2009; World Bank 2012). The conditions for agriculture are best in the northern and central provinces and are even among the best in SSA (Diao et al. 2007), as soils and climate are very suitable for rainfed agriculture there (Mucavele 2009). Most of the population, however, lives in the southern provinces, where soil and precipitation conditions are much less suitable and vulnerable to drought (World Bank 2012). The challenge is to develop infrastructure that enables surplus regions to become competitive against neighboring countries. Although since 2000 Mozambique has experienced growth in its agricultural sector, the factors that led to this growth - increased yields from implementing fundamental technology improvements from very basic farming techniques used by smallholder farmers as well as expanded land areas for agricultural production (FAO 2014) — did not require a lot of policy effort and are not sustainable. Sustainable policies, such as infrastructure improvements and greater use of agricultural inputs, should be implemented so that Mozambique can achieve its goals of food self-sufficiency and agricultural growth.

\section{Table 2.3 Comparison of fertilizer usage of selected SSA countries}

\begin{tabular}{lc}
\hline Country & $\begin{array}{c}\text { Average fertilizer application } \\
\text { rate (kg/ha) }\end{array}$ \\
\hline Kenya & 29 \\
Malawi & 39 \\
Mali & 9 \\
Zambia & 8 \\
Mozambique & 5 \\
\hline
\end{tabular}

Source: Chianu et al. (2008).

\section{Water Policies in Malawi and Mozambique: Irrigation}

Given their direct and indirect effects on food, energy, and water security, irrigation scheme interventions can be considered nexus interventions. Irrigation schemes can directly impact water security through changes in water availability if water is diverted from drinking sources, directly affect energy security if energy is required for their operation (for example, for motorized schemes), and indirectly affect food security through their potential to increase crop yields and diversification.

With the acceleration of population growth and repeated droughts over the past decades, Malawi is expanding its support for irrigation (Mulwafu and Nkhoma 2002). In Malawi a total area of 104,000 hectares is irrigated (Malawi, MoAIWD 2015). Since 1994 the irrigated area increased more than four times (Kaluwa, Mtambo, and Fachi 1997). In several areas of Malawi, the irrigation boom is accompanied by the transfer of irrigation management from the government to farmers. Stakeholder participation in irrigation management is expected to encourage sustainable operations by inducing a sense of ownership and responsibility among farmers. Ideally, farmers would plan, build, maintain, and manage their community's irrigation scheme. This transfer of ownership and management from the government to farming communities, called irrigation management transfer (IMT), is rife with challenges and has not yet been entirely successful (Nkhoma and Mulwafu 2004).

In 2001, Malawi adopted a new irrigation policy and act that put IMT into motion. IMT was intended to reduce government spending, improve irrigation scheme performance and sustainability, reduce water use and waste, and empower farmers through their involvement in water user associations (WUAs). IMT was attempted in the 1990s by the Technical Cooperation Project funded by the Food and Agricultural Organization of the United Nations (FAO), which aimed to rehabilitate and hand over 16 
irrigation schemes to local communities (Malawi, MoAIWD 1999). This attempt failed because it lacked funds for rehabilitation, participating farmers had no detailed program, and the pilot process had not been documented well enough for lessons to be learned (Malawi, MoAIWD 2000). Another attempt at IMT was made the following year through the Likangala irrigation scheme; however, this progressed slowly for numerous reasons: funding was not secure, farmers had not been trained in irrigation management, a WUA had not been established, farmers were expected to provide free labor in rehabilitation work, and rehabilitation work conflicted with farmers' field cultivation work during the wet season (Nkhoma and Mulwafu 2004). In addition were conflicting perceptions of who owned the schemes. Village heads, welloff farmers, and poor farmers all tended to see the handover as an opportunity to reclaim what they perceived as rightfully theirs (Nkhoma and Mulwafu 2004). This climate of uncertainty demoralized farmers and created conflict that, because of cultural precedence, ended up being resolved by village heads rather than the scheme committees (Nkhoma and Mulwafu 2004). With careful planning, clear communication between stakeholders, and adequate funding, these issues can be overcome and the transfer of irrigation management in Malawi could be successful.

In 2010, Malawi began promoting the Green Belt Initiative (GBI), which is a large-scale irrigation policy for smallholders and commercial farmers to use Malawi's water resources, predominantly Lake Malawi. The Malawian government has offered investors agricultural land near the country's three biggest lakes and perennial rivers to install irrigated agriculture on 1 million hectares by relocating villages (Chinsinga and Chasukwa 2012). The initiative is a prime example of a nexus intervention aiming at higher agricultural output of food and cash crops with the goals of increasing macro- and microlevel food security and decreasing poverty. Ecker, Breisinger, and Pauw (2011) simulate economywide effects of the GBI by increasing the area of agricultural land under irrigation and comparing this simulation to the status quo in 2010. Through subsequent increases in agricultural and nonagricultural growth, they find that greater diversification in the agricultural sector and the rest of the economy results in reductions in poverty as well as caloric and nutritional deficiencies. This implies that the GBI has a large potential to increase food security at the macro- and microlevels. On the other hand, land grabbing through commercial farmers and investors acting under the GBI has been an enormous problem because customary land without official land rights is taken from smallholder farmers. Moreover, smallholders who participate in the GBI must comply with seasonal land collectivization, which constrains them to plant a prescribed crop and shift away from their usual intercropping and diversification, which had served as a safety net (Chinsinga and Chasukwa 2012). These requirements may negatively affect macro- and microlevel food security, yet their impacts have yet to be analyzed. Given the energy-intensive nature of most irrigation schemes, energy security is expected to be directly affected by this policy as well, yet no studies explicitly examine this effect. In terms of water security, the initiative directly improves water security by increasing water access. Most irrigation schemes are located near Lake Malawi, which could decrease the lake's water levels and water flowing out of rivers, making it difficult to maintain sufficient water levels to produce hydroenergy. Since impacts from the GBI on water and energy security may be substantial and remain unknown, a comprehensive analysis of macro- and microlevel nexus effects is essential to quantify the actual trade-offs and synergies of the GBI.

Mozambique obtains water from various sources, and its water equity is better compared with surrounding countries. Yet water supply disparities exist in Mozambique, and this aspect can be improved by developing the corresponding infrastructure. Its agricultural sector uses 73 percent of used water (Mutondo et al. 2013) and relies mostly on rainfall, which varies widely across regions, ranging from 1,000 to $2,000 \mathrm{~mm} / \mathrm{m}^{2}$ annually in northern regions, around $1,200 \mathrm{~mm} / \mathrm{m}^{2}$ in central regions, and 800 to $1,000 \mathrm{~mm} / \mathrm{m}^{2}$ in coastal and southern regions (Mucavele 2009). Southern regions are particularly vulnerable to droughts, and severe water shortages occur regularly there in the dry season (Mutondo et al. 2013). At the other extreme, most states are affected by severe rains and threatened by flooding (Mozambique, MINAG 2010). Floods and droughts pose major challenges because of their regularity and the lack of measuring and mitigating services. Mozambique's 104 river basins, of which 8 are major water basins, are another major water source (Direcção Nacional de Águas 1999). Rivers supply 53.8 percent of the water used in Mozambique, and most flow from the highland plateau of Central Africa to 
the Indian Ocean. The rivers' water levels are highly seasonable: basins are completely filled for only 3-4 months of the year (Mutondo et al. 2013). Mozambique's downstream location means that its water quantity and quality depend on upstream countries (Mozambique, MINAG 2010). Therefore, Mozambique needs to cooperate with upstream countries, and water management at a regional level is necessary. Internationally, policies have been developed by international organizations, such as the South African Development Community (SADC), which addresses biophysical and socioeconomic issues of water management related to agricultural, household consumption, and electricity use as well as disaster management (SADC 2011). However, the implementation of regional policies, in addition to the national policies with different national interests, lead to an increase of complexity and so far not to efficient utilization of synergy effects (Maupin 2013).

Mozambique has a high potential for irrigation near its large river basins. It is estimated that 3.3 million hectares of arable land could be under irrigation, yet currently only 120,000 hectares have installed irrigation schemes and only 50,000 hectares are actually irrigated (Mozambique, MINAG 2010). Two large schemes are along the Limpopo River: a 25,000-hectare scheme focused on sugarcane production in Chokwe District, and another scheme focused on rice production in Xai District. Other irrigation schemes are on the Incomati, Buzi, and Zambezi Rivers, with a total capacity of 34,000 hectares (Mutondo et al. 2013). Other important water sources for irrigation schemes are Lake Niassa, Lake Chirua, and groundwater. Available groundwater is $17 \mathrm{~km}^{3}$ annually and is mostly centered in the Zambezi and Incomati basins (Mutondo et al. 2013). Most water sources are not efficiently used, and several problems exist: overall storage capacities are too small, which causes distribution difficulties during dry years; a limited number of smallholder farmers are able to profit from the schemes; and technical and organizational capacities for irrigation are at low levels (Mozambique, MINAG 2010).

Given the multitude of stakeholders involved, many challenges and opportunities await for developing policies to support sustainable water use. Policies related to regulatory and management decisions are especially critical. Policymakers have attempted to address some of these issues, yet their results are mixed. A first step was the 1991 national Water Law, which regulated that all water resources are to be state owned and implemented by the National Water Council (CNA) as an interpolicy institution, which consists of members of ministries working in issues related to agriculture, mineral resources and energy, health, and coordinated environmental action (Mutondo et al. 2013). The largest difficulty was coordinating water management between the environmental and mining ministries as well the local governments (Mutondo et al. 2013). In addition, the policy failed to implement a flood control system, a polluter-pays principle, and an efficient water use control system. Moreover, its centralized organization limited the accessibility of small-scale farmers. This highlights the difficulties explained in Section 1 on implementing nexus policies. A few years later in 1995, a new water policy was implemented, which addressed environmental and economic issues, led to integrated water resource management, and included other strategic implementations such as decentralized water management and a sustainable water supply (Mutondo et al. 2013). The Water Tariff Policy enabled communities to recover the cost of providing water from the consumers (Direcção Nacional de Águas 1999). Policies with respect to irrigation focused on activating and managing large schemes, which is necessary because large shares of the irrigation schemes along the Limpopo River had not been in use. Nevertheless, after its implementation, technical equipment was destroyed by floods or not operational due to poor management.

Subsequent national irrigation policies intended to address these failures. For example, in 2010 the Ministry of Agriculture in collaboration with the International Water Management Institute developed the National Irrigation Strategy (Gemo 2011). Increasing sustainable water management is also a pillar of the Comprehensive Africa Agriculture Development Programme (CAADP) (Mozambique, MINAG 2010) and is thus a priority area in the Strategic Plan for Agricultural Development (PEDSA). The main goals are to develop water quantity data for each source, improve the education system of state employees, and inaugurate a public discourse on sustainable water usage (Mozambique, MINAG 2010); however, the attainment of these goals may be threatened by a lack of water experts (Gemo 2011). The National Plan for Investments in the Agrarian Sector (PNISA) also contains a subprogram, the 
Hydroagricultural Exploitation Program, for investments into irrigation schemes for both small- and large-scale farmers, which is estimated to cost US $\$ 836$ million $^{4}$ (Mozambique, MINAG 2013). The plans for irrigation are very specific and focus on sustaining, activating, and developing irrigation infrastructure as well as supporting the construction of dams and reviving wetlands for agricultural use. In particular, they support the construction of small-scale irrigation schemes that are locally managed with a capacity of less than 200 hectares and support strengthening medium- and large-scale schemes that are centrally managed and cover more than 200 hectares. The program also entails expanding the use of wetlands for agriculture and finding investors for the development of water storage infrastructure. Additionally, the national irrigation institute was established to provide research and management skills to the water sector and to be able to deal with new challenges resulting from increased irrigation. At the commodity level, the government plans to spend most of its resources on increasing rice production, which should support the large irrigation schemes at Limpopo River, since Mozambique is not self-sufficient in this staple crop. In addition are planned improvements in small-scale irrigation schemes for tomato production, which requires a continuous water supply (MINAG 2013). If these multipronged approaches are correctly implemented in Mozambique, its irrigation system could be greatly improved to reach more smallholder farmers and to improve its food and water security.

\section{Energy Policies and Malawi and Mozambique}

Energy policies reviewed in this section include hydroenergy and bioenergy. The discussion on hydroenergy reveals the strong linkage between water and energy and food security. Likewise, the discussion on bioenergy strategies reveals a strong linkage of the FEW nexus.

\section{Hydroenergy}

Hydroenergy is a form of renewable energy that has the potential to decrease dependency on fossil fuels, while simultaneously triggering changes in national food, water, and energy security. If water is abundant, it is a clean and renewable source for producing electricity, which can greatly enhance macrolevel energy security (Hellegers et al. 2008). Apart from the obvious effect on macrolevel energy security, hydroenergy entails synergies and trade-offs at the macro- and microlevels of the other nexus components. With regard to water security, hydropower generation creates a sectoral conflict concerning the allocation of water for hydropower and irrigation for agricultural production. Although hydropower does not necessarily have an effect on the quantity of water itself and hence macrolevel water security, a dam can influence the timing and amount of downstream water flow enormously and thus reduce water availability for food production during certain seasons or times of the day. This is very problematic when droughts occur, which have become more frequent from climate change, particularly in SSA countries (Molle et al. 2008). A dam could thus directly decrease access to water and indirectly affect food security at both the macro- and microlevels. Moreover, water losses through evaporation of reservoirs could be significant, which could negatively impact water security (Hoff 2011). On the other hand, effects of hydropower on water and food security can go in the opposite direction when hydroenergy is used for groundwater pumping to increase irrigation (McCornick, Awulachew, and Abebe 2008). At the same time, hydroenergy production can be negatively affected by the agricultural sector. Therefore, a comprehensive analysis of these varying impacts is required to analyze impacts of hydroenergy on the FEW nexus. In SSA is a large scope for boosting electricity production from hydropower, as only 5 percent of its potential hydropower is used (Hoff 2011). In SSA, less than one-tenth of the rural population uses clean energy (electricity, liquefied petroleum gas (LPG), natural gas, biogas, and other energy that does not cause indoor pollution), yet this is even lower in Malawi and Mozambique - just 0.4 percent and 0.21 percent, respectively (Table 2.4). Promoting clean energy in the region is a challenging task, despite its high potential.

\footnotetext{
${ }^{4}$ The reported budget for the subprogram is 25 billion Mozambican meticals (MZN). For calculating the dollar amount, we used the average exchange rate (MZN 29.91/US\$1) for 2013, reported by the Bank of Mozambique.
} 
Table 2.4 Source of energy for rural population in SSA (\% of households)

\begin{tabular}{lllll}
\hline Energy source & Malawi & Mozambique & Southern Africa & SSA \\
\hline Electricity & 0.28 & 0.15 & 3.98 & 1.32 \\
LPG & 0.06 & 0.06 & 11.37 & 6.20 \\
Natural gas & 0.01 & 0.00 & 3.62 & 1.82 \\
Biogas & 0.01 & 0.00 & 0.42 & 0.16 \\
Kerosene & 0.09 & 0.00 & 4.73 & 2.58 \\
Clean energy & 0.40 & 0.21 & 18.15 & 8.81 \\
Coal & 0.12 & 0.88 & 0.77 & 0.95 \\
Charcoal & 1.38 & 0.14 & 3.47 & 7.12 \\
Wood & 96.91 & 99.06 & 75.05 & 80.64 \\
Cow dung & 0.07 & 0.20 & 1.98 & 2.39 \\
Crop residues & 0.45 & 0.00 & 0.42 & 2.31 \\
Other & 0.01 & 0.10 & 0.39 & 0.67 \\
\hline
\end{tabular}

Source: WHO (2015).

Note: $\quad$ SSA = Africa south of the Sahara. * Clean energy includes electricity, liquefied petroleum gas, natural gas, biogas, and other energy that do not cause indoor pollution (IEA 2013a).

Despite the significant part of hydroenergy in increasing macrolevel energy security, in 2011 only about 7 percent of Malawi's households - mostly in urban areas - were attached to the electricity grid (World Bank 2011a). Moreover, the cost of electricity is subsidized by about 60 percent to help reach the government's goal of having electricity be affordable for the poor. Nevertheless, since most of the poor are not connected to the grid, the subsidy targets mainly middle- and high-income households (UNDP Malawi 2007). This means that further developing hydroenergy would increase macrolevel energy security but would probably have only a small effect on poverty and microlevel energy security, particularly among the poor who depend mostly on biomass. Nevertheless, Malawi's Rural Electrification Program (MAREP) aims to reduce poverty by transforming rural economies and has electrified a large number of rural trading centers (Pemba 2013). To meet greater electricity demands, the World Bank and the Malawian government are increasing the number of hydroenergy power plants through the Energy Sector Support Project (World Bank 2011a). Both programs will probably not decrease the current overdependency on biomass in the short run but are likely to increase microlevel energy security in the long run. Further research is needed on linkages between hydropower generation and the distribution on food, water, and energy security at the macro- and microlevels to analyze this policy from a nexus perspective.

Malawi's electricity is almost exclusively generated through hydropower by the Electricity Supply Corporation of Malawi (ESCOM) and is susceptible from its dependence on Lake Malawi. Upstream activities like deforestation through land clearing for agricultural production as well as forest degradation for firewood and charcoal production have increased surface runoff. This, in turn, increases siltation and debris flowing into rivers, which increases the costs of running hydropower facilities because of extensive cleaning. In addition, fertilizer debris in the water increases nutrients and thus the growth of water weeds, complicating the cleaning of turbines (ESCOM 2013). Since Malawi's four power plants are stationed along its largest river, the Shire, which is the only outflow of Lake Malawi, their ability to function is highly dependent on the lake's water levels. Recent droughts and sedimentation in the lake through erosion, stemming from increased land clearing for agriculture in the catchment areas, have led to low water levels, resulting in unreliable electricity production and frequent outages (UNDP Malawi 2007). However, there is no evidence that hydroenergy leads to conflicts of upstream and downstream water uses in Malawi. Instead, it appears that water security and agricultural activity has a larger influence on hydropower production than the other way around, making hydropower a suitable policy intervention to increase energy security without negatively affecting water and food security. 
Electricity contributes significantly to the balance of trade and is one of Mozambique's most important export goods. About 80 percent of the produced energy is exported to South Africa and Zimbabwe (Bensch, Peters, and Schraml 2010). The small share of own energy consumption results from an unforked electricity grid in Mozambique, where just 18 percent of households have access to electricity (Mahumane, Mulder, and David 2012) and just 8 percent in rural areas (Bensch, Peters, and Schraml 2010). The Action Plan for the Reduction of Absolute Poverty (PARPA) I+II for 2001 to 2009 (GOMOZ 2001, 2006) contained a policy strategy with the aim to enable large shares of the population to have access to the electricity grid. The policy mainly addressed households and governmental entities in rural areas. However, Poverty Reduction Action Plan (PARP) for 2010 to 2014 changed its energy focus to only electrifying educational, administration, and health institutions in rural areas (GOMOZ 2011). Despite the recent discovery of other natural resources, ${ }^{5}$ the largest potential of all energy sources in Mozambique is hydropower, amounting to a total installation capacity of 12.5 gigawatts (Bensch, Peters, and Schraml 2010). Hydroenergy production is predominantly in the Zambezi River Basin (Bensch, Peters, and Schraml 2010), as well as along smaller rivers in Manica, Tete, and Niassa provinces (Malawi, MoE 2009). The Cahora Bassa, which is one of the largest hydropower plants in southern Africa, contributes 87 percent to the total energy produced within the country (Bensch, Peters, and Schraml 2010) and has a capacity of 2,075 megawatts (Mahumane, Mulder, and David 2012). In addition, the government plans to construct new hydropower plants, such as in Mphanda Nkuwa and Cahora Bassa North Bank (Mahumane, Mulder, and David 2012).

Although hydropower increases Mozambique's macrolevel energy security enormously, positive effects on microlevel energy security are estimated to be very small because only a fraction of the population has access to electricity and biomass remains the main source of power (Chambal 2010). In the short run, the construction of Cahora Bassa has had disastrous consequences on local livelihoods and ecosystems. Although the dam was constructed with the object of improving irrigated farming and flood control, the prevention of flooding through the dam has led to negative effects on food security. When the river receded after the annual flooding of agricultural land, it left behind nutrient-rich soils that were decisive for smallholders' food security in an area with low and irregular rainfall (Isaacman and Sneddon 2000). Moreover, the dam disrupted the seasonal flow of the river into the Zambezi delta, which was essential for agricultural production and livelihoods (Isaacman and Sneddon 2000). However, this implies a twofold effect on water security: the now constant flow of water should increase water security, as households near the river are less dependent on rainfall, yet there may be less water security from the loss of seasonal flooding of agricultural lands.

\section{Biofuels}

Biofuel policies have direct impacts on all three nexus securities, thereby entailing several trade-offs with an ambiguous net effect. Because of growing demand for biofuels from policies calling for increased biofuel blending of gasoline, rising fossil fuel prices, and vastly increasing energy demand from emerging economies (OECD and FAO 2013), the following nexus trade-offs emphasize the crucial importance of managing biofuel expansion sustainably. The most widely discussed issue concerning the promotion of biofuels is the trade-off between energy and food security. Increased production of biofuels may lead to land taken away from food production and land investments (sometimes referred to as "land grabbing"), thus lowering food availability at the micro- and macrolevels. In addition, high international demand for feedstocks common to both food and biofuel production has already driven up prices, thereby threatening access to food (HLPE 2013). If poor smallholder farmers are able to participate in biofuel production, this

\footnotetext{
${ }^{5}$ In the last decade, large natural gas resources were discovered and tapped. Most important gas discoveries are the Pande and Temane gas fields and the discoveries within the Buzi Block (Mahumane, Mulder, and David 2012). Coal mining began in Tete Province, allowing Mozambique the ability to become a very important player in the world market of fossil fuels (ICF International 2012) and to significantly increase its GDP (Biggs 2012). To realize these opportunities, foreign direct investment is necessary (Mahumane, Mulder, and David 2012). Achieving profits for large shares of the population, especially among those living in regions rich in natural resources, is a challenge (ICF International 2012).
} 
may raise rural incomes and thus their access to food. Nevertheless, their economic well-being would be in sync with market prices of biofuels, which could be detrimental given their volatility. If farmers rely on an inedible biofuel crop for income and at harvest time are unable to fetch an adequate market price, their food purchasing power may be affected. Alternatively, if the staple crop of people who are or close to food insecure is also a biofuel crop, these people may be driven further into food insecurity as the market price for that crop increases with greater global demand. This is especially true for Malawi and Mozambique, where the populations rely heavily on maize (a biofuel crop) for calories (Naylor et al. 2007). However, opportunities exist to improve the purchasing power of smallholders and reduce their vulnerability to price shocks (see Ewing and Msangi (2009) for best practices to increase welfare gains). The prospect of increasing rural incomes is a prominent motivation for biofuel policies in developing countries and is often accompanied by hopes that biofuel production will create jobs and stimulate economic growth. In addition, many developing countries promote biofuels to increase macrolevel energy security by reducing their dependency on fuel imports (Arndt, Msangi, and Thurlow 2010). If, however, vast areas of forests need to be cleared to avoid negative effects on food security, microlevel energy security may be reduced since the rural population would have to walk farther to collect sufficient firewood (Gao et al. 2011). Yet, if biofuel is produced by tree crops, microlevel energy security could be directly enhanced through an increased provision of firewood. Concerning water security, biofuel production can have a high additional demand for water, depending on the crop, thus competing with food production for scarce water resources. For example, sugarcane, which is used to produce ethanol, is very water intensive and often requires irrigation (De Fraiture, Giordano, and Liao 2008). Moreover, other impacts on water security are indirect from deforestation and land clearing, for example soil loses its capacity to absorb rainwater and groundwater reserves are put under additional pressure. The utilization of vast areas of unused land for biofuel production is not an option for Malawi given its high population density.

Energy policies in Malawi have largely focused on liquid energy for transportation. Investment in renewable energy has increased almost six-fold between 2004 and 2011 (UNDP 2013), yet it needs to reach 0.7 trillion between 2010 and 2030 to achieve sustainable development (IEA 2013b) and its production capacity remains underutilized (SEI 2011). Since 1982, Malawi has produced ethanol from sugarcane, which is one of the country's most important industries (UNDP Malawi 2007) with blending ranging from 10 percent to 24 percent (SEI 2011). Sugarcane production is dominated by large-scale plantation farming on estates. Outgrower schemes that began in the 1990s produce about 20 percent of sugarcane output today. The sugar sector is the second largest formal employer in Malawi and provides permanent jobs for almost 6,000 people and seasonal work for more than 4,000 people, making the industry essential for employment generation and growth. In recent years, the government has aimed to enhance the poverty reduction potential of the sector by increasing the productivity of outgrowers through collective irrigation schemes under the GBI (Herrmann, Grote, and Brüntrup 2013). In addition to sugarcane, several jatropha projects for biodiesel production are under way. About 25,000 farmers grow jatropha, predominantly as a field fence (Kambewa and Chiwaula 2010). The planting of jatropha is promoted mainly by Bio Energy Resources Ltd. (BERL), a Malawian-based company funded through corporate social responsibility efforts by international companies. BERL buys jatropha nuts from smallholder contract farmers under the condition that it is not planted on land used for food production. The company hopes to be cash positive in 2014 (BERL 2014); however, given the doubts about the feasibility of jatropha production for smallholders, the profitability of jatropha production remains to be seen.

No studies examine the impact of ethanol or sugarcane production on food, water, or energy security in Malawi. Herrmann, Grote, and Brüntrup (2013) evaluate the impact of sugarcane smallholder outgrower schemes on poverty and income at the microlevel in one of the two largest sugarcaneproducing areas. They find that these schemes can help reduce poverty from 72 percent to 18 percent and ultrapoverty from 56 percent to 13 percent. In addition, income increases on average by a factor of three, which is likely to greatly improve microlevel food security. The study finds that wealthier farmers are more likely to participate in sugarcane outgrower schemes, indicating hurdles for poorer farmers, such as 
initial investments. This potential trade-off emphasizes the importance of analyzing the actual effects of ethanol and sugarcane production on food security as well as on water and energy security in a broader, economywide framework that can examine impacts on households with different wealth levels.

In Mozambique, liquid biofuel is another big energy player yet is more relevant for higher income groups. The country's liquid biofuel production potential, 7 exajoules, would ensure fuel self-sufficiency and even enable exports (WWF 2008). Arndt et al. (2010) find that biofuel strategies could increase GDP and the income of the poor. Developing the biofuel sector requires engagement of policymakers and foreign investors (Thurlow 2012) because the necessary production of crops and building of refining sites is capital intense. The ministry of agriculture supported the production of jatropha in the early $2000 \mathrm{~s}$ (Gemo 2011). The plan involved improving access to credits and inputs and supporting smallholder farmers through outgrower schemes. Sugarcane was also promoted as possible commodity for biofuel (Mozambique, MINAG 2013).

Foreign investment into Mozambique increased after the country opened a platform for assessing its biofuel potential and promoted biofuel production (Mozambique, MINAG 2013). In addition, due to its abundance of unused state-owned land, Mozambique was an early focus of international biofuel investors, such as in sugarcane and jatropha production from Brazilian, British, Chinese, Portuguese, German, and Italian investors (Thaler 2013). Estimates of the amount of land area for biofuel production that was planned to be or was actually acquired range from 2.3 to 2.7 million hectares, and estimates of investments into the biofuel value chain are US\$3 billion (Nhantumbo and Salomão 2010). Although some of these investments have been realized (World Bank 2011b), most have not been implemented or have not been successful (Benson, Woldeyohannes, and Mogues 2013; Locke and Henley 2014). Reasons include the lack of viability of jatropha; length of project implementation; bureaucratic obstacles concerning the acquisition of land use licenses; the 2007/2008 food price crisis, which forced the ministry of agriculture to shift its focus from promoting biofuel to producing food (Gemo 2011); and the drop in oil prices at the start of the financial crisis in 2008, which made biofuels not profitable since their profitability depends on the oil price being higher than US\$70. As a consequence, farmers who engaged in biofuel production via outgrower schemes suffered income losses (Thaler 2013). The Mozambican government introduced the Policy and Strategy for Biofuels in early 2009, with the objectives of higher energy security, employment and income generation, and improved food security for the rural population (Borras Jr., Fig, and Suárez 2011). For example, Mozambique's biofuel program stipulates that staple food crops should not be used for biofuel production and that areas of extreme monoculture should be avoided (Mozambique, MINAG 2013). Thus, the government considers only two nexus sectors in its biofuel strategy. One reason why the water sector may be neglected in Mozambique's biofuel strategies is that, as discussed above, Mozambique has vastly abundant and underexploited water resources.

Arndt et al. (2010) simulate economywide effects of increasing biofuel production in Mozambique and analyze effects on macrolevel food security. Since they assume that total biofuel production is exported, no direct effects on energy security accrue. Altogether, the simulations show positive effects on economic growth and poverty. Their model distinguishes between the production of jatropha through smallholder contract farmers and sugarcane on plantations, with the latter being capital intensive and exclusively financed from abroad and the former being relatively more labor and land intensive. Since the cultivation of biofuels exclusively on unused land is constrained by insufficient infrastructure, the authors assume that about half of the increase in biofuel production will be undertaken on land formerly cultivated with other crops. This leads to a reduction in available land for food crop production and thus lowers domestic food availability, especially for cereals. However, simulations find positive effects of jatropha production on both poverty and food security, especially under the assumption that jatropha production leads to technology spillovers concerning the production of food crops (Strasberg 1997). It is important to note that Arndt et al. (2010) do not examine the economic viability of jatropha as a biofuel crop for smallholder farmers. Arndt et al. (2010) also find that because of increased water demand from biofuel production, output in the water sector almost doubles in one of their biofuel scenarios compared with the baseline without biofuel investments. Arndt et al. (2010) are among the first to implicitly consider all three nexus dimensions from an economywide perspective. Since demand for 
biofuels is unlikely to decrease, it is imperative to find a suitable framework to quantify the abovedescribed trade-offs and synergies of biofuel production on food, water, and energy security.

\section{Agroforestry}

Deforestation is increasing in SSA, with rates being nearly twice as high in Malawi compared with Mozambique (see Table 2.5). One method to decrease deforestation is agroforestry, which is a prime example of a nexus intervention because it can directly influence all three nexus sectors. Agroforestry refers to cultivating both agriculture (crops, pasture, and animal husbandry) and woody plants (predominantly trees) on the same land to realize multiple benefits. The agroforestry practice of agrisilviculture, where crops are planted together with woody plants, is of primary interest for the FEW nexus (Nair 1985). Examples of agri-silviculture include planting trees around fields as shelterbelts and intercropping crops and trees. Agri-silviculture is directly related to integrated soil fertility management that aims at increasing agricultural productivity through a locally adapted combination of mineral and organic fertilizers (Garrity et al. 2010). The production of organic fertilizer is the most significant potential benefit of agroforestry. Soil quality can be significantly improved by nitrogen-fixing trees that function as a natural fertilizer through enhancing nitrogen in the ground. Moreover, the decomposition of leaves, fruits, and other biomass and residues produced by trees increases available nutrients in the ground (Nair et al. 1999). In addition, agroforestry helps conserve soil since trees decrease erosion from wind and water (Ruark, Schoeneberger, and Nair 2003). Better soil quality leads to higher agricultural output (Akinnifesi et al. 2010), while fruit trees or legumes can contribute to better agricultural production and dietary diversity (Kwesiga et al. 2003; Dawson et al. 2013). Therefore, agroforestry has the potential to significantly improve agricultural output and food security at both the macro- and microlevels.

Table 2.5 Increasing deforestation in Africa south of the Sahara

\begin{tabular}{llllllll}
\hline Country/region & \multicolumn{3}{c}{ Forest area ('000 ha) } & \multicolumn{3}{c}{ Annual change } \\
\hline & $\mathbf{1 9 9 0}$ & $\mathbf{2 0 0 0}$ & $\mathbf{2 0 0 5}$ & $\mathbf{1 9 9 0 - 2 0 0 0}$ & $\mathbf{2 0 0 0 - 2 0 0 5}$ & $\mathbf{2 0 0 5 - 2 0 1 0}$ \\
\hline Malawi & 3,896 & 3,567 & 3,402 & -0.9 & -0.9 & -0.99 \\
Mozambique & 43,378 & 41,188 & 40,079 & -0.5 & -0.5 & -0.53 \\
Southern Africa & 229,296 & 21,8150 & 21,2550 & -1.0 & -1.2 & -1.2 \\
SSA & 664,115 & 629,340 & 612,449 & -0.5 & -0.6 & -0.5 \\
\hline
\end{tabular}

Source: FAO (2005).

With regard to water security, agroforestry has the potential to increase both water quality and water availability. Runoff from fields that contains sediments, fertilizer, and pesticides can flow into waters. Trees around fields and along river banks are able to reduce this runoff since water and contaminants need more time to infiltrate into the soil. Moreover, trees allow for greater decomposition of pesticides and animal waste (Dosskey 2002; Ruark, Schoeneberger, and Nair 2003). In terms of water availability, trees function as "biotic pumps" and are able to draw moisture from oceans" increasing evapotranspiration and precipitation to supplement the regional water cycle (Ellison, Futter, and Bishop 2012). It can thus be concluded that agroforestry is very likely to have positive impacts on both macrolevel water security through higher availability of water and microlevel water security by increasing the quality of water and access to water if more water is induced into the water cycle. Agroforestry can improve macrolevel energy security through higher availability of fuelwood as well as microlevel energy security through better access. In particular, since trees incorporated into agriculture can provide fuelwood (Watson et al. 2000; Cooke, Kohlin, and Hyde 2008), this would reduce the amount of time spent collecting firewood. Moreover, trees can produce other valuable products and thus help reduce rural poverty and improve food security (Ruark, Schoeneberger, and Nair 2003).

Agroforestry has been practiced in Malawi for several generations and its use has recently expanded through government initiatives. For many generations, planting crops under the Faidherbia 
albida tree, which has nitrogen-fixing and reverse leaf phenology, has been a widespread indigenous treecropping practice (Rhoades 1995). With reverse leaf phenology, leaves go dormant and are shed exactly when crops are being planted, thus serving as additional fertilizer. The leaves begin to grow again only at the end of the growing season. Therefore, the tree provides minimal competition with crops for water or nutrients (Barnes and Fagg 2003). Many studies have found large positive effects of the Faidherbia albida tree on crop yields. For example, Saka et al. (1994) report increases in maize yields by 100-400 percent. A disadvantage of Faidherbia is that it requires six years after planting to lead to significant gains in crop yields. To realize agroforestry benefits sooner, other nitrogen-fixing trees, such as leguminous pigeon pea trees, which have the additional benefit of providing food (Garrity et al. 2010), could be planted simultaneously with Faidherbia. Indeed, intercropping maize with leguminous trees is a popular agroforestry system in southern Malawi, and long-term experiments find that this practice increases maize yields an average of about twofold (Akinnifesi et al. 2007). Ajayi et al. (2006) find that intercropping maize with nitrogen-fixing trees increases yields to provide between 57 and 114 extra person-days of maize consumption in Zambia. Although no thorough impact assessment has been done to quantify the actual effect of agroforestry on food security in SSA, a qualitative assessment in Malawi, Zambia, and Mozambique finds that the majority of agroforestry-practicing farmers experience increases in yields, income, food security, and firewood availability (Akinnifesi et al. 2008). Since the 1980s, Malawi's government and the World Agroforestry Center have supported agroforestry research (Garrity et al. 2010). More recently, the Malawi Agroforestry Food Security Program from 2007 to 2010 was managed by the World Agroforestry Center, the Malawian government, farmers' associations, and NGOs. This project aimed to reduce the burden of purchasing seedlings among the poorest farmers by distributing seeds for fertilizer, fodder, and fruit trees, as well as trees that can be used to produce timber and fuelwood. After an initial testing period, the program was successfully scaled up to 40 percent of Malawi's districts, encompassing about 1.3 million of the poorest Malawians (Garrity et al. 2010; Beedy et al. 2012). Albeit not an in-depth impact evaluation, Mwalwanda et al. (2012) find that compared with farmers' yields without agroforestry, maize yields increased by about twofold.

Mozambique also has a long history of agroforestry, dating back to the colonial times when the Portuguese introduced cashew trees along the whole coast of Mozambique. The area where the trees were planted corresponds almost to one-third of the country's area (Unruh 2002). Cashew trees are predominantly grown by smallholders and intercropped with cassava or maize. Due to a long history of civil war, replacement of old cashew trees did not occur, leading to a deterioration of the cashew sector in the 1980s and 1990s. The low productivity of cashew trees today emphasizes the need for renewed efforts to infuse cashew agroforestry in Mozambique (Unruh 2002). In 2002 the World Agroforestry Center initiated an agroforestry pilot project in Tete province. To increase yields, incomes, and food security, the project distributed seeds for fertilizer, fruit trees, and fodder trees as well as trained farmers in agroforestry techniques to build teams that would be able to function as extension agents for other farmers (Linyunga, Matakala, and Chintu 2004). However, the project has not been evaluated to assess actual effects on food security. Although Ajayi et al. (2011) report findings of a qualitative assessment of agroforestry benefits, only about half of the 57 interviewed farmers reported increases in food security.

Before future agroforestry-related programs are launched, we recommend conducting an ex ante quantitative policy analysis through policy simulations to investigate the effects on water and energy security, as well as the economic impacts at the household level. The promotion of agroforestry and analysis of its effects on food security are important, especially since the government needs a sound strategy for phasing out FISP in Malawi (Garrity et al. 2010) and rebuilding agroforestry in Mozambique. The evidence thus far favors agroforestry as a FEW nexus intervention that can trigger synergies among all three sectors, yet in-depth analyses of these linkages are critical for quantifying the impacts.

\section{Improved Cookstoves}

Woodfuel consumption in SSA is the largest in the world (Ouédraogo 2009) and is projected to continue increasing beyond 2030 (UNEP 2007). Consequently, even though the SSA population accounts for only 
12 percent of the global population, the region accounts for 54 percent of the 186.7 million $\mathrm{m}^{3}$ of woodfuel consumed in 2008 (FAO 2011) and 54 percent of the 43.6 million tons of charcoal consumed in 2007 (FAO 2010). About 90 percent of the wood harvested in SSA is used as woodfuel (UNEP 2014). It is estimated that in SSA, 76 percent of the population depends on biomass resources as their primary cooking energy (IEA 2006). Cooking alone uses 33 percent of the fuelwood and about 90 percent of wood harvested in Africa is used as fuelwood (FAO 2006). In Mozambique, the main energy source for cooking in nearly all rural households is firewood, whereas in urban households 49.4 percent rely on firewood and 41.9 percent on charcoal as their main energy source (see Table 2.6). In urban areas, where charcoal needs to be purchased, the usage of improved cookstoves (ICSs) can have a strong impact on the poorest households. Takama et al. (2011) show that cooking energy costs correspond to one-third of the yearly national minimum wage.

Table 2.6 Main energy sources used for cooking in Mozambique (\%)

\begin{tabular}{lccc}
\hline Energy source & Urban & Rural & Total \\
\hline Electricity & 1.8 & 0.2 & 0.7 \\
Natural gas & 5.9 & 0.1 & 1.9 \\
Kerosene/paraffin & 0.4 & 0.3 & 0.2 \\
Coal & 0.2 & 0 & 0.1 \\
Charcoal & 41.9 & 2.1 & 14.5 \\
Firewood & 49.4 & 96.9 & 82.2 \\
Animal dung & 0 & 0.5 & 0.3 \\
Other & 0.3 & 0 & 0.1 \\
Number of households & 4,338 & 9,617 & 13,955 \\
\hline
\end{tabular}

Source: INE (2009).

The reliance on solid biomass for cooking entails a variety of challenging and devastating outcomes. The use of solid biomass for cooking has severe consequences for people's health. Indoor pollution from traditional cooking stoves results in 1.6 million deaths annually (Rehfuess 2006), which outnumbers deaths from malaria (1.2 million people in 2006) (IAE 2006). Bailis, Ezzatti, and Kammen (2007) forecast that between 2000 and 2030, solid biomass use in SSA will lead to 8.1 million deaths among children from lower respiratory infection and 1.7 million deaths among women from chronic obstructive pulmonary disease. The overdependence on woodfuel has led to repressive woodfuel harvesting legislations in several SSA countries (Horst and Hovorka 2009), which has serious implications for women since they are mostly burdened with collecting firewood (Ewing and Msangi 2009). On a positive note, recent evidence has also shown that declining biomass has prompted communities to plant and protect trees, yet empirical evidence on how such a favorable trend could be enhanced is scarce (Cooke, Köhlin, and Hyde 2008). Research is needed to investigate ways to revise the repressive woodfuel policies and enhance current efforts to plant and protect trees. Woodfuel consumption per se does not lead to significant deforestation in rural areas but is limited to peri-urban areas, as most woodfuel is harvested from scrub, bush fallow, agroforestry trees, and woodlots (Mead 2005). The fast growth of urban centers in the SSA region and with it the increasing demand for charcoal, due to insufficient electrical power generation, puts increasing pressure on forest reserves, leading to increased soil erosion and poor watershed management. It is obvious many challenges and impacts result from traditional cooking practices, some of which are difficult to measure.

ICSs are generally made of durable materials that will last at least 5-10 years, and many are sold at affordable prices with guarantees. ICSs promoted in Malawi and the traditional three-stone cookstove are shown in Figure 2.4. Using the same food cooked in all three stove types, Mwase and Malikani (2012) show that the rocket cookstove is the most efficient, followed by the Chitetezo Mbaula both in energy use 
and cooking time (Figure 2.5). A lot of progress has been made in the adoption of ICSs, though most is concentrated in Asia. The World Health Organization of the United Nations (WHO) and United Nations Development Programme (UNDP) (WHO and UNDP 2009) compiled information from surveys in 140 countries and found that about 166 million households using solid bioenergy use ICSs, including 116 million in China, 13 million in the rest of East Asia, 20 million in South Asia, 7 million in SSA, and 8 million in Latin America. These figures do not include the factory-made newer stoves that have been produced in the past five years, of which about half a million cookstoves have been sold in India, South Africa, Uganda, Honduras, and Guatemala. As Table 2.7 reveals, the distribution of ICSs is extremely limited: In Mozambique, only 1.0 percent of urban and 0.1 percent of the rural households use an ICS. Earlier efforts to promote the use of ICSs by the World Bank and other donors did not yield significant success (Manibog 1984; Gifford 2010), and most gains have been in eastern and southern Africa (shown in Figure 2.6). Among problems that faced such programs were technical, institutional, and financial issues. Additionally, the projects lacked impact analysis, which could have helped in designing more effective programs. Subsidies hindered the development of efficient marketing programs in developing countries (Gifford 2010). Efforts also suffered from a lack of commitment from developing countries: only 10 percent of ICS investments was from government funding, with the remainder coming from NGOs (50 percent), projects (29 percent), and private sources (11 percent) (Gifford 2010). Significant efforts have been initiated to promote the uptake of ICSs. The United Nations Foundation launched the Global Alliance for Clean Cookstoves (UN Energy 2011), which complements existing international programs such as the German BMZ and the Dutch Ministry of Foreign Affairs. This demonstrates the limited attention that the rural solid bioenergy sector has received in the region from governments. Instead, as described hitherto, energy policies in SSA have been directed toward electricity, fossil fuel, and most recently liquid bioenergy, rather than biomass energy, which is used by the majority of the poor.

Figure 2.4 Types of cooking stoves: clay, rocket, and three-stone traditional

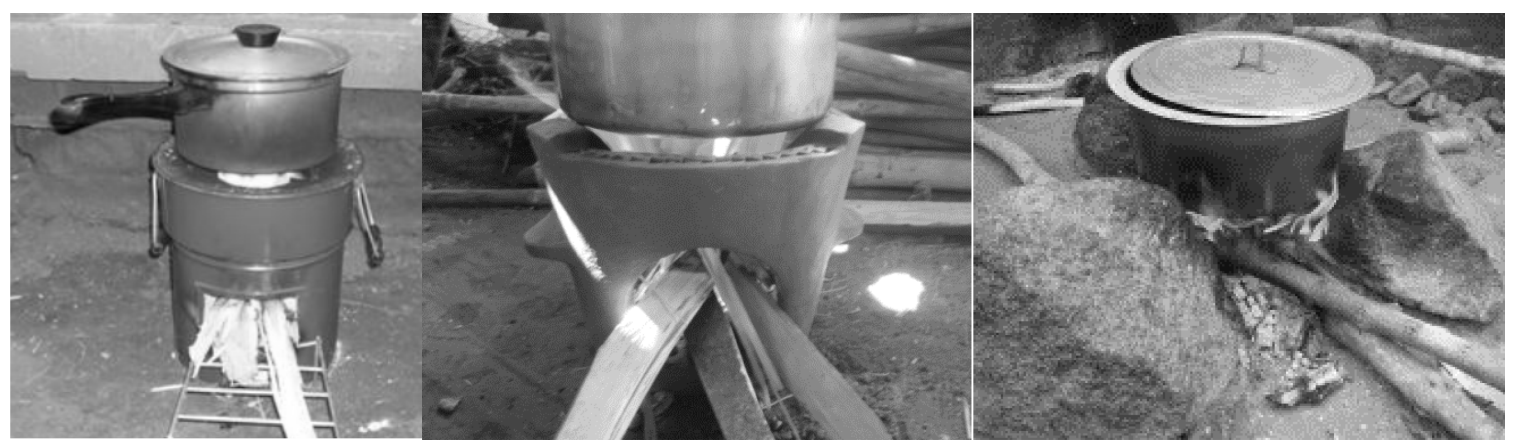

Source: Mwase and Malakini (2012) and Sustainable Engineering Lab (2009).

Table 2.7 Usage of cookstove type in Mozambique (in percent)

\begin{tabular}{lccc}
\hline Stove type & Urban & Rural & Total \\
\hline Improved stove & 1.0 & 0.1 & 0.4 \\
Traditional stove & 99.0 & 99.8 & 99.6 \\
Number of households & 3,971 & 9,568 & 13,539 \\
\hline
\end{tabular}

Source: INE (2009). 
Figure 2.5 Comparison of fuelwood consumption and cooking time for cooking stoves

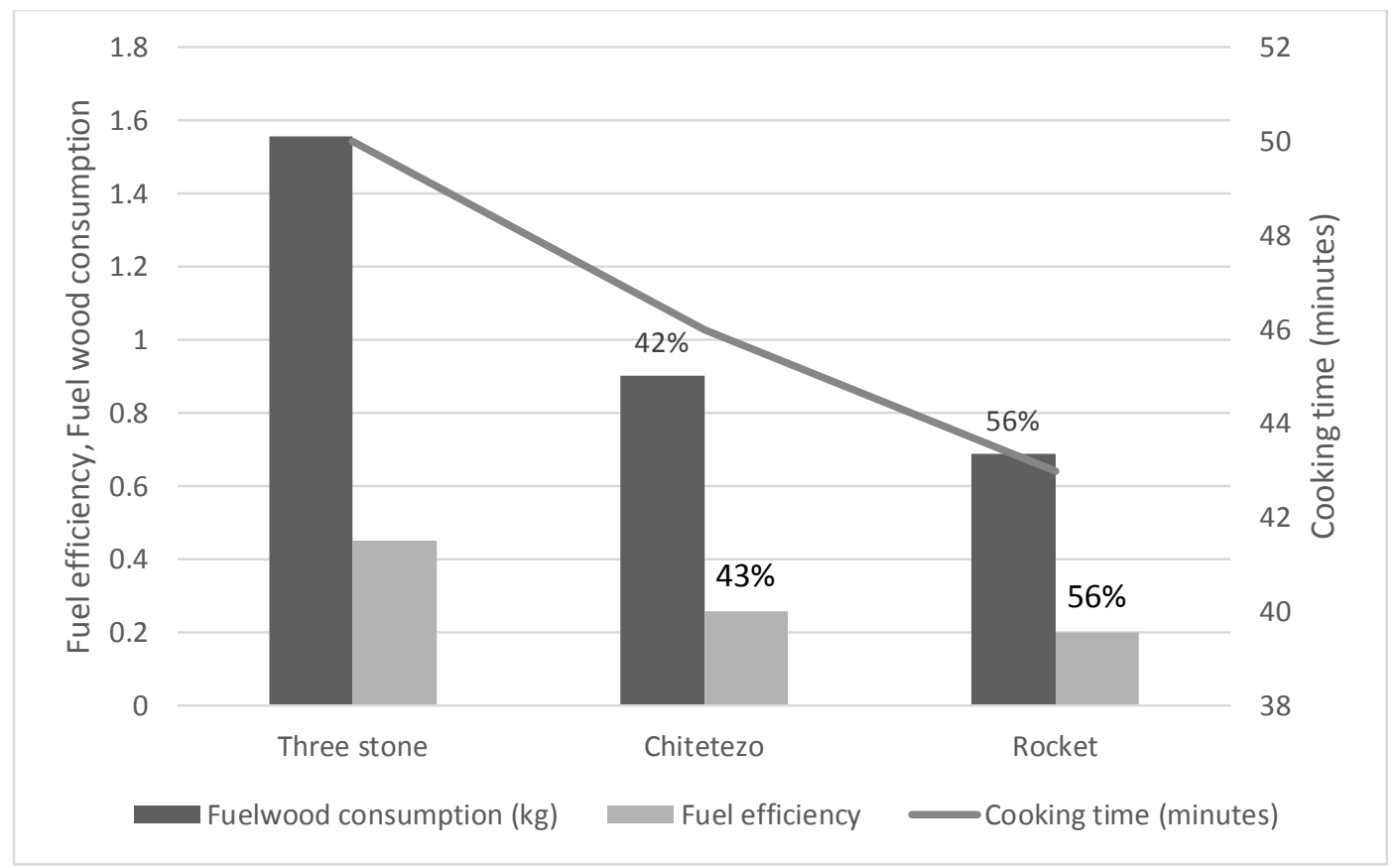

Source: Calculated from Mwase and Malakini (2012) for Malawi.

Notes: Fuelwood efficiency $=$ Dry wood equivalent consumed $(\mathrm{kg})$ per kg of food cooked.

Percentage on top of histogram indicates percentage change due to switching from the traditional three stone to improved cooking stove.

Figure 2.6 Distribution of cookstove programs in Africa south of the Sahara, 1984-2010
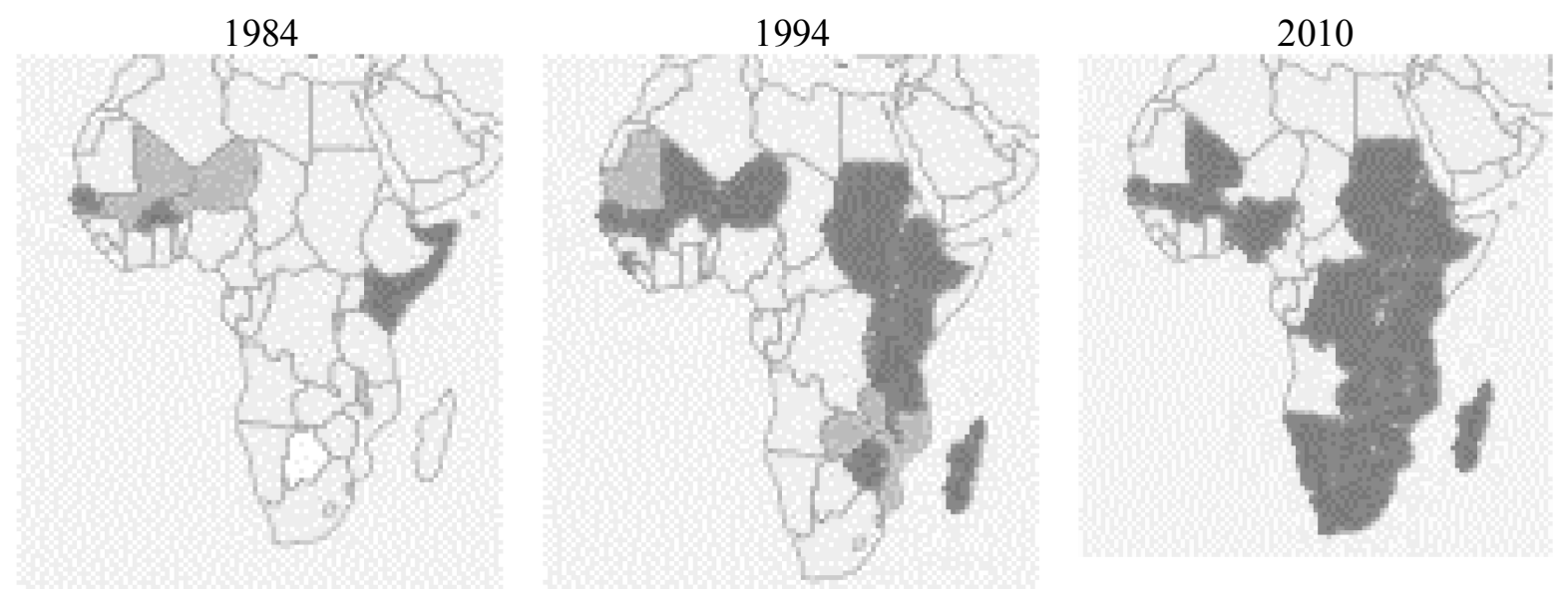

Source: Extracted from Gifford (2010). 
ICSs are gaining traction among the development community and policymakers because their proper use reduces firewood usage and smoke emissions, which are expected to preserve forestland, reduce greenhouse gas emissions, lower the incidence of respiratory diseases, and reduce the amount of time spent collecting firewood or cash requirements for the world's poorest people. Due to the severe impact of indoor pollution from traditional cooking stoves on the health of children and women, using ICSs can be an important contribution to the Millennium Development Goals (MDGs) (Takama et al. 2011). Reduction in firewood expected from proper use of ICSs could translate into microlevel effects on food, water, and energy security. Nutrition may improve as ICS adopters have more fuel available to cook a wider variety of foods, including foods that require longer cooking time like legumes. In addition, food security implications are possible if time spent collecting firewood is reduced, given that this activity is extremely labor intensive. There may be indirect effects of ICS by reducing the amount of time women spend collecting firewood, which may allow more time for women to be engaged in childcare, paid labor, education (UNDP 2005), and leisure. To estimate these benefits, it is necessary to know what activities replace firewood collection. For example, is leisure time increased, or on-farm or off-farm employment? Water security at the household and individual levels may improve if ICS adopters are more likely to boil drinking water. This, in turn, may also improve food utilization due to a lower presence of water-borne diseases. Direct effects on microlevel energy security from ICS adoption are yet to be determined, as an increase in cooking and water-heating activities may negate fuel savings - a research topic that has not yet been examined.

Potential effects of ICSs on the macrolevel are twofold. First, the time-saving component can lead to an increase in labor availability by releasing labor from collecting firewood to other activities. If onfarm or off-farm employment increases, this could have large economywide linkage effects and increase output and growth. Higher economic growth indirectly effects water and energy security by increasing demand for both water and energy. Moreover, higher agricultural output will improve macrolevel food security. This effect could be especially large given that firewood is predominantly collected by women who are usually employed in food crop production to a larger extent than men. Given that these potential economywide effects are highly dependent on actual behavioral changes from the introduction of ICSs, an in-depth study at the microlevel is necessary to find out whether people really spend less time collecting firewood and if so, what activity they replace firewood collecting with. This information could be used to inform a model to simulate the economywide effects of ICS. The second potential effect is from improved microlevel food security from different types of foods being cooked with ICS. As mentioned above, higher nutrient intake may be expected if ICS adopters use gains in firewood efficiency to cook more fuel-intensive food items like legumes. A link between better nutrition and higher labor productivity is undoubted in the literature, although it has been difficult to establish a clear empirical relationship between the two, especially since the relationship is bidirectional (Strauss and Thomas 1998; Hoddinott 2011). Higher labor productivity should enhance output of all sectors and thus increase macrolevel food security. Again, effects on macrolevel water and energy security might be negative in case there is higher demand of firewood if the stove is used the same amount of time. A potential labor productivity effect of ICS interventions will be very difficult to measure and might not be feasible to include in a study measuring economywide effects of ICSs.

Only a few studies have analyzed impacts of ICS adoption, none of which have had a large sample size. Habermehl (2008) finds that the promotion of ICS adoption by school lunch programs in Malawi had an overall positive economic effect at the national level. The study used cost-benefit analysis, cost-effectiveness analysis, and macroeconomic criteria to assess the benefits of firewood savings from seven institutions using a type of ICS called rocket stoves. Rocket stoves are enclosed metal stoves that are highly fuel efficient. The type of rocket stove in the study at hand is for institutional cooking (for schools, hospitals, offices, and so forth), but other types are for individual household use and for tobacco-drying sheds. Findings showed that based on a period of 10 years and a discount rate of 3 percent, considering the benefits of avoided fuel costs, preserved forestland, and greenhouse gas reduction, the investment of $\$ 1.00$ provides a return of $\$ 5.16$ (Habermehl 2008). In January 2013, Malawi launched the National Improved Cookstoves Task Force with the goal of getting 2 million households to 
adopt ICSs by 2020 (Concern Universal 2013). Concern Universal is one of several NGOs promoting the adoption of ICSs. A recent study (Concern Universal 2012) assessed the sociocultural acceptability of ICSs in Mulanje, Dedza, and Balaka districts. Among the conclusions drawn from the study are the following:

- After adopting the Chitetezo Mbaula (a type of ICS made of clay), households reported a 44 percent reduction in firewood collection trips.

- Firewood savings can improve disposable incomes as firewood purchases make up 12-23 percent of weekly household expenditures.

- Emissions levels of promoted ICSs are not low enough to meet WHO recommendations.

As ICSs are moved into the spotlight of development agendas, the actual human health and forest resource benefits need to be quantified. In addition, the question of how best to promote widespread adoption of fuel-efficient cookstoves should be explored. 


\section{MACROLEVEL ANALYSIS OF NEXUS INTERVENTIONS}

The previous section examined how nexus interventions in Malawi and Mozambique affect food, water, and energy security at different levels of the economy. Although these policies were targeted to trigger a specific sector of the nexus, they invariably affected all three either directly or indirectly. The resulting synergies and trade-offs concerning food, energy, and water security from these policies are often disregarded by policymakers. Although the previous section provided insight into the realized effects of implemented nexus interventions, the complexity of these effects requires a quantitative analysis of nexus policies from the nexus perspective so that relevant synergies and trade-offs can be evaluated, which can help guide interventions (Dervis, De Melo, and Robinson 1982). Quantitative analyses can be conducted before (ex ante) and after (ex post) a policy has been implemented. Ex ante analysis comprises building behavioral economic models and simulating policy measures (Sadoulet and de Janvry 1995). An ex post analysis of policies is usually undertaken at a smaller scale through impact evaluations of interventions at the household level. While an impact evaluation is essential to examine the success or failure of a policy with regard to the actors targeted, the advantage of ex ante policy analysis is the possibility to simulate different policies and capture complex effects arising through linkages between different levels and actors of the economy (Diao and Thurlow 2012). Since simulation models can be built at varying levels of aggregation (economywide, sector level, or microlevel), the question arises as to which kind of model should be used for analyzing policies within the nexus framework. This section provides a brief discussion on theories behind existing models before reviewing their advantages and disadvantages for analyzing synergies and trade-offs from policies on food, water, and energy security.

\section{Theoretical Foundation and Composition of Models}

The essence of quantitative policy analysis through economic simulation models is to reproduce the actual structure of the economy as the structure determines how policies influence economic agents, sectors, and markets. The structure itself is determined by linkages within an economy, resulting from the circular flow of goods and services, which is typically represented by the flow of income between different actors and markets in the economy in exchange for these goods and services. Figure 3.1 illustrates this flow of income in an open economy in a simple and stylized manner. In this figure, rectangles represent economic actors or sectors that include all households and farms, and circles denote markets. The arbitrary starting point is households from which income is in the form of private consumption that flows as sales revenue to producers and is intermediated through product markets, thereby encompassing consumption linkages between producers and households. Producers use this revenue to pay wages to households for the factors of production that they offer, which are intermediated through factor markets. Producers can also use revenues to buy intermediate inputs at the product market from other producers. These production linkages encompass intersectoral or backward and forward linkages if the output of one sector is used as an input in another sector. At the same time, different sectors or producers compete for (limited) resources or production factors, such as labor, land, and capital, creating trade-offs (compare Diao and Thurlow 2012). These linkages imply that an intervention targeting a nexus sector invariably affects all three nexus sectors. According to our definition, an intervention can be termed a nexus intervention if it has at least one direct effect on one sector and indirect effects on the other sectors. Because a nexus intervention is usually aimed at improving food, water, or energy security, it exerts a direct effect on at least one of the sectors by affecting its output. This policy then has indirect multiplier effects on other sectors working through production and consumption linkages on both product and factor markets, which is explained in further detail below.

At the heart of basically every economic model lies the finding of the optimal and efficient allocation of scarce resources involving utility maximization of households and profit maximization of producers. Both consumers and producers converge at factor and product markets. Following neoclassical microeconomic theory, an optimal allocation of limited resources can be reached only if during an equilibrium of supply and demand for all markets. Thus, any distortion in the equilibrium of one market 
through changes in demand and supply in one sector, such as through an intervention, must change the optimal resource allocation. A new equilibrium is reached through the price mechanism, that is, until supply equals demand. These general equilibrium effects influence supply and demand of other sectors through consumption and production linkages on factor and product markets (compare Felderer and Homburg 2005). An intervention aimed, for example, at increasing food availability through a fertilizer subsidy would increase demand for land from the food sector, potentially decreasing available land for biofuel production. On the other hand, an increase in food output would decrease the price of food, resulting in households having more money to spend on nonfood products from other sectors such as fuel. Although this market interaction is at the core of the economy, other actors and institutions are also affected through linkages. As shown in Figure 3.1 save income and pay taxes to the government. The government saves, consumes, and makes transfers to households. Savings flow back to producers in the form of investments. Eventually, most countries trade with the rest of the world, selling their products as exports and buying foreign products as imports. In summary, this figure demonstrates that an intervention that appears to influence only a small part of the economy will invariably affect other parts of the economy through the described linkages.

Figure 3.1 Circular flow of income in an economy

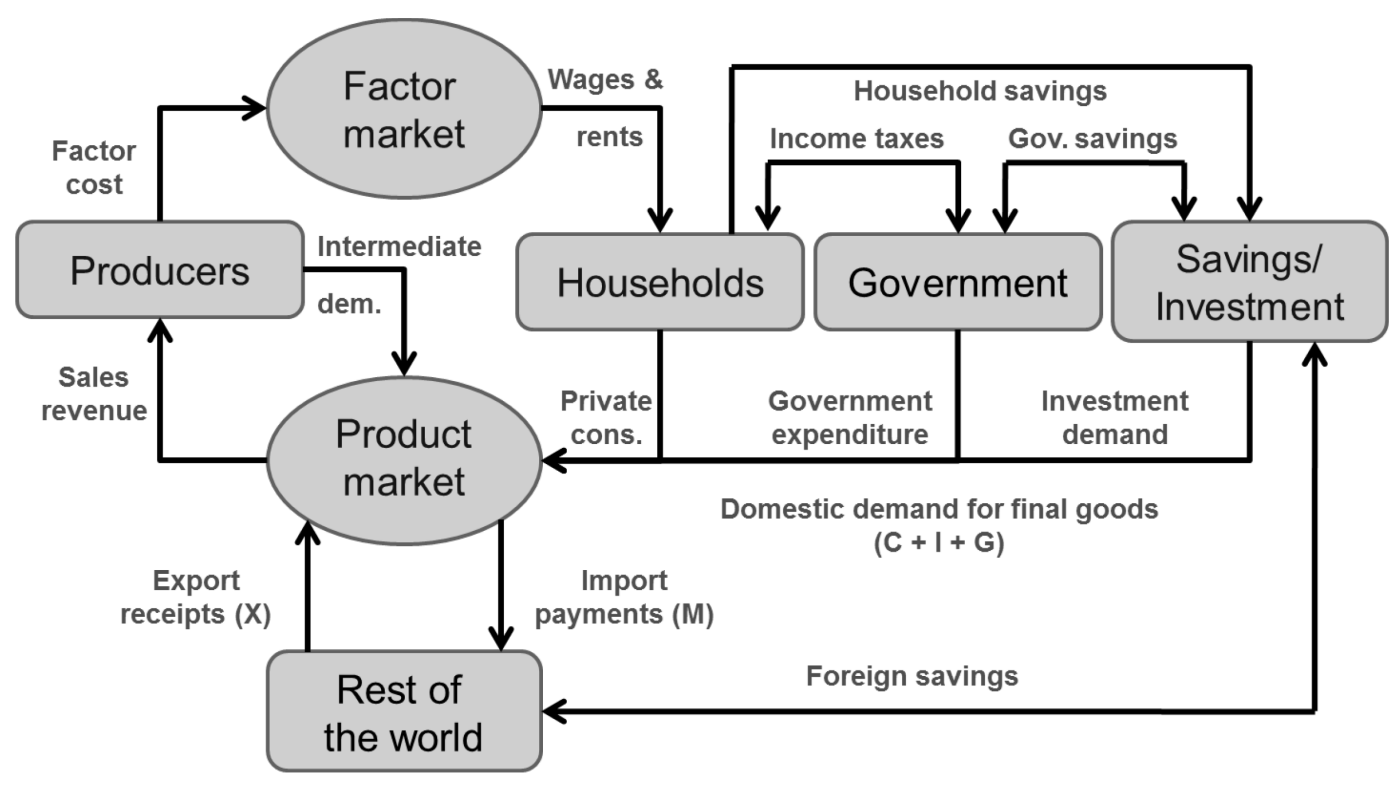

Source: Authors, based on Breisinger, Thomas, and Thurlow (2009).

To depict these linkages, simulation models are usually composed of two parts. The first part is a theoretical model with a system of behavioral equations for different actors and markets and is based on economic theory. The second part consists of empirical data, which is used to calibrate the model's parameters to make the model a more realistic representation of economic processes. How many economic processes the model encompasses and the amount of detail in which it covers different actors and markets depends on its purpose. Two types of economic models for policy analysis are distinguished, depending on their focus. These are partial and general equilibrium models. A general equilibrium or an economywide model that mirrors the complete circular flow of income and thus the structure of the economy (shown in Figure 3.1) therefore encompasses all linkages between economic actors and markets. Partial equilibrium models, on the other hand, encompass only a part of an economy, such as a market or sector, and ignore the effect of policy measures on the rest of the economy by usually assuming that the effect is small or nonexistent (Piermartini and Teh 2005). In light of the goal to analyze the effects of policies on the FEW nexus, this assumption of partial equilibrium models appears to be problematic. 
However, since economywide models represent the whole economy of a country, a rather high level of aggregation is necessary. This means that not every economic actor can be represented in the model. Instead, there are representative agents. To find the most suitable model for an analysis of nexus policies, the next section briefly reviews partial and general equilibrium models.

\section{Partial Equilibrium Models}

Although partial equilibrium models are not suitable for a thorough analysis of a nexus intervention, some existing models can be useful to analyze specific parts of the nexus in more detail, given their flexibility, especially in spatial terms. An example for the energy sector is the MARKAL model of the International Energy Agency (IEA), which allows the simulation of different energy policies and scenarios such as climate change to find an energy-technology combination that minimizes the total cost of the energy system in both monetary and environmental terms (IEA ETSAP 2014). However, this model is available and suitable mostly for applications to industrialized countries (IEA ETSAP 2014). Similar models for energy policy analysis are the MESSAGE model, which is also used to analyze effects of interventions on access to energy for the household sector (IIASA 2013), and the LEAP model of the Stockholm Environment Institute (SEI), which allows energy policy analysis on a global, national, and city scale (SEI 2013). The SEI also maintains a model for water system planning and water policy analysis called WEAP (WEAP21 2014). Because water is a natural resource that is often not traded at a market, WEAP and other water simulation models incorporate hydrological features to be able to capture the actual water supply. In terms of food security, the International Food Policy Research Institute's (IFPRI's) International Model for Policy Analysis of Agricultural Commodities and Trade (IMPACT) model is a partial equilibrium model of the agricultural sector that is able to simulate effects of climate change or biofuel production on macrolevel food security on a global, regional, and national scale. In addition, IMPACT has been combined with a water simulation model to encompass linkages between food production and water supply and demand (Rosegrant and the IMPACT Development Team 2012). IMPACT can therefore simulate effects of policy measures on both water and food security, providing results on the magnitude of first-order effects.

The Climate, Land, Energy, and Water (CLEW) project ${ }^{6}$ is the only modeling approach that integrates all three nexus sectors by combining the above-mentioned energy model LEAP, the water simulation model WEAP, and the Agro-Ecological Zoning (AEZ) land use model. The CLEW approach can model effects of policy measures on energy and water demand and supply, as well as changes in land use for different crops (Welsh et al. 2014), making it a suitable modeling framework to quantify firstround effects of interventions on macrolevel food, water, and energy security. Nevertheless, a combination of partial equilibrium models, such as in the CLEW project, is not able to capture linkages with other sectors or macroeconomic growth effects concerning savings and investment. In addition, it is not able to simulate effects on individual or microlevel securities, that is, on access to food, water, and energy, which can only be captured by microsimulation models.

\section{Microsimulation Models}

To examine nexus effects at the microlevel, that is, households and individuals, a microsimulation approach is more suitable because it provides information about the distributional effects of policies. At the center of microsimulation models is the product demand and factor supply behavior of the individual based on preferences and budget constraints. Behavioral microsimulation models commonly consist of a microlevel dataset with detailed socioeconomic data and characteristics of the individual that mirrors the economic environment, individual budget constraint, and a theoretical model of the individual's behavior usually based on welfare maximization. Since the theoretical model is calibrated with a microlevel

\footnotetext{
${ }^{6}$ The CLEWS project is a collaborative by the International Atomic Energy Agency (IAEA), the Royal Swedish Institute of Technology in Stockholm (KTH), the International Institute for Applied Systems Analysis (IIASA), Stockholm Environment Institute (SEI), United Nations Department of Economic and Social Affairs (UNDESA), Food and Agriculture Organization of the United Nations (FAO), and United Nations Industrial Development Organization (UNIDO).
} 
dataset, the model can replicate the heterogeneity of individuals observed in the population and can model their behavioral response quite accurately, instead of modeling only representative agents (Bourguignon and Spadaro 2006). In this way, the model allows an evaluation of all relevant trade-offs of nexus interventions at the individual level because it precisely identifies losers and winners. Although microsimulation models are most suitable to evaluate welfare effects of interventions at the microlevel, they remain partial equilibrium models because they analyze only the supply side of factor markets and the demand side of product markets with prices being treated as given (Creedy and Kalb 2005; Diao and Thurlow 2012). Thus, microsimulation models are not able to measure effects on other sectors or simulate effects of nexus interventions on macrolevel food, energy, and water security. These effects can only be simulated only by economywide models, which are discussed in the following section.

\section{Computable General Equilibrium Models}

Bazilian et al. (2011) argue for a systems approach in terms of a modeling framework that can capture all interactions between food, water, and energy security. They also emphasize the importance of system boundaries that are large enough to encompass decisive interactions while being small enough to enable useful analyses. In terms of a nexus analysis at the country level, the most suitable system boundary is the national economy itself, which calls for a framework that is able to capture all relevant interactions within a country. Economywide models, called CGE models, encompass the complete flow of income as shown in Figure 3.1 and hence incorporate all consumption and production linkages between economic actors and markets. The decisive feature of CGE models is that they combine both the macro- and the microlevels and consist of microeconomic foundations and macroeconomic closure rules.

A comprehensive framework requires a comprehensive database, which in CGE models is the social accounting matrix (SAM). A SAM captures all economic flows for a particular year across product and factor markets within an economy in the form of accounts for six types of economic "institutions." These institutions are activities, commodities, production factors, domestic institutions (households, producers, and the government), capital, and the rest of the world. Accounts are organized in a square matrix in which each account has a row and column listing all expenditure and income flows. The SAM is a consistent and complete framework, as every income flow corresponds to some expenditure flows. Accounts for each institution can be disaggregated into any number of accounts, such as different regions, subsectors, or household types, depending on the objective of the study. However, the higher the level of disaggregation, the more demanding the data requirements. The main data sources of a SAM are inputoutput tables to capture production linkages; nationally representative household surveys for information on consumption and income distribution; government statistics for taxes and transfers; and national accounts for information on income and expenditures of producers, balance of payments, and trade (Sadoulet and De Janvry 1995).

The second component of CGE models is formed by an analytical model of economic equations to define the behavior of economic institutions and the key economic mechanisms driving the simulations. Although the functional forms of equations in the theoretical model can differ depending on the purpose, Walrasian general equilibrium theory forms the basis of the model by assuming profitmaximizing producers and utility-maximizing households with their supply and demand decisions on factor and product markets (Wing 2004). All these markets must clear at equilibrium product prices and factor wages, which is the main driver of the simulations. The behavioral assumptions, however, imply that the model works with representative agents and not individual households. This reduces the detail of the models because a completely disaggregated model is not feasible given size and data requirements (Böhringer, Rutherford, and Wiegard 2003).

This microconsistent framework together with macroeconomic closure rules ensures that the effect of nexus interventions on food, water, and energy security can be fully captured by incorporating the change in the behavior of individual actors as well as the change in macro dimensions and their respective linkages. It is thus possible to simulate nexus interventions at all economic levels, such as the introduction of improved cookstoves at the household level, the promotion of biofuel production in the 
agricultural sector at the sector level, and economywide shocks like terms-of-trade shocks at the macrolevel. The results can then provide evidence on how interventions change the availability of food, water, and energy at the national level. In addition, the results generate information on distributional effects at the aggregated household level and thus changes in access to resources. This allows for an evaluation of trade-offs at the macro- and microlevels. Therefore, the CGE model is the most suitable model for ex ante quantitative policy analysis of nexus interventions. Nonetheless, it is important to keep in mind that CGE models are not predictive tools and can evaluate only possible outcomes. Moreover, due to their fundamental structure as elaborated above, CGE models can capture only nexus linkages (that is, production and consumption linkages), which work through markets and prices. Because the nexus encompasses natural resources that are not traded at markets, this might necessitate the combination of economic and ecological models to fully capture the nexus. Therefore some caveats exist concerning an economywide analysis of food, water, and energy security at the macro- and microlevels in developing countries. These problems are related to issues including data requirements, structural issues, and general model features, which are discussed below.

Because the agricultural sector is usually the largest sector in developing countries, output data are available through national accounts and input-output tables. Even though agricultural sectors are dominated by the subsistence economy, household surveys are able to measure consumption and production quite accurately. This means that the CGE model can simulate effects of policy interventions on food availability and thus macrolevel food security quite well. However, because CGE models work with representative household groups at a more aggregated level, they are not able to capture important distributional effects within these representative groups and thus actual changes in microlevel securities. Yet, this disadvantage can be reconciled by combining CGE models with microsimulation modules: Several papers have combined CGE models with poverty and nutrition modules by linking each household from a household survey top-down with its corresponding representative household in the CGE model (Arndt et al. 2008; Arndt et al. 2010; Pauw and Thurlow 2011; Pauw et al. 2012). With regard to microlevel poverty analyses, potential changes in consumption of representative households and in prices evoked by interventions are imposed on the respective survey households to recalculate household consumption expenditures and compare them to a poverty line (Pauw et al. 2012). For the nutrition module, the initial caloric availability of surveyed households is calculated on the basis of their food consumption. Through the top-down link of representative households' consumption to the surveyed households, changes in food consumption in the CGE model are imposed on the surveyed households to estimate potential changes in caloric availability, which are compared to a measure of caloric requirements (Pauw and Thurlow 2011). This method captures the effect of nexus interventions on access to food within the CGE framework.

The analysis of energy security poses other difficulties. Formal energy supply in the form of electricity or fuel plays an extremely small role for satisfying energy demand in developing countries. Most energy supply comes from informal sources in the form of firewood and charcoal. Only formal energy supply and demand is captured by input-output tables, supply-use tables, or national accounts and can thus be easily incorporated into a SAM to simulate policy impacts on macrolevel energy security. On the other hand, informal energy markets can be measured only by surveys. Because markets for charcoal are illegal in many SSA countries, only a few studies have such data, such as Kambewa et al. (2007) for Malawi. Moreover, firewood and wood for charcoal production is collected from forests, essentially for free in monetary terms, and are thus not traded on markets. The costs of access to energy come in the form of time, as people have to walk hours to collect wood, which decreases their available time for other activities such as food production (Fisher 2004; Bandyopadhyay, Shuamsundar, and Baccini 2011). If the household survey used in a CGE model were to account for the costs of rural energy production, such as through collection time by calculating the opportunity costs of collecting firewood, it would be possible to analyze policy effects on microlevel energy security by assuming explicit changes in households' time allocation. Moreover, a behavioral microsimulation model, such as a farm household model, or reliable empirical data might be necessary to inform the CGE model about potential changes in time allocation 
through an intervention. The analysis of policy effects on the availability of wood as a natural resource, however, will likely require a combination of CGE and forestry models.

Similarly, difficulties in analyzing water security in developing countries stem from the nonexistence of markets. Apart from formal water distribution systems, which are available mainly in urban areas, water in rural areas of developing countries is a free good, which means that it is difficult to measure water supply and demand in economic terms (Ponce, Bosello, and Giupponi 2012). Water supply comes from rain (green water), lakes, rivers, and the ground (blue water). Without formal distribution systems, the only costs of water are extracting costs, time costs for carrying it, and political economy costs if limited water sources are shared. The measurement of demand and supply for water within the CGE approach thus requires more elaborate methods. Hassan and Thurlow (2011) solve the nonexistence of water markets for South Africa by building a Water-SAM that accounts for water demand of different sectors and regions. With the help of experimental field data, water-use-crop-yield production functions are estimated that allow for the calculation of demand curves and shadow prices of irrigation water for different crops. Industrial and domestic water demand supplied by the formal water distribution system is estimated on the basis of supply use data and household surveys. This SAM is then used within a WaterCGE model to analyze the economywide effects of water market policies in South Africa and shows potential policy trade-offs for different sectors and households. A Water-SAM is thus well suited to analyze the demand side of water security within the economywide nexus framework. In contrast, water supply in developing countries depends largely on hydrological considerations. Since it is not feasible to assume unlimited water supply in the long run, the most accurate approach to measure effects of nexus interventions on water availability is most likely in the form of hydroeconomic modeling, such as a combination of a CGE model with a hydrological model.

This review of different models has shown that the quantitative analysis of nexus interventions is an extensive undertaking that requires many considerable challenges to be addressed. However, this mirrors the complexity of the issue itself and emphasizes the need for a comprehensive policy analysis framework that allows a better insight of effects on the nexus. Economywide simulation models are able to show trade-offs and synergies of nexus interventions at all economic levels and can help guide policymakers' understanding of nexus effects ex ante and convince them to think beyond their respective political departments.

\section{Small-Scale Irrigation Suitability Ex Ante Analysis for Malawi and Mozambique}

In this subsection, we propose a methodology for a small-scale irrigation analysis that builds upon existing work at IFPRI (Xie et al. 2014; You et al. 2011). We apply various criteria to score the irrigation suitability of each pixel. The criteria and datasets we propose to use for this ex ante analysis are shown in Table 3.1 and 3.2, and the proposed scoring scheme is shown in Figure 3.2. 
Table 3.1 Criteria and data for ex ante suitability analysis

\begin{tabular}{|c|c|c|}
\hline Criteria & Dataset & Explanation \\
\hline Topography (slope) & $\begin{array}{l}\text { SRTM (Shuttle Radar Topography Mission) } \\
\text { elevation data (USGS 2015) }\end{array}$ & $\begin{array}{l}\text { Small scale irrigation (SSI) tends to occur in } \\
\text { areas with gentle slope. }\end{array}$ \\
\hline $\begin{array}{l}\text { Groundwater } \\
\text { accessibility }\end{array}$ & $\begin{array}{l}\text { BGS (British Geological Survey) quantitative } \\
\text { groundwater map for Africa }\end{array}$ & $\begin{array}{l}\text { The BGS map provides estimates of depth to } \\
\text { groundwater, indicating if groundwater depth } \\
\text { is } 0-7 \text { meters, } 7-50 \text { meters, and } 50-250 \\
\text { meters. It is used as an indicator of } \\
\text { accessibility to groundwater. }\end{array}$ \\
\hline $\begin{array}{l}\text { Distance to perennial } \\
\text { surface water }\end{array}$ & $\begin{array}{l}\text { Global Lakes and Wetlands } \\
\text { Database (Lehner and Döll, } \\
\text { 2004), the V-Map Perennial } \\
\text { Streamlines dataset (National } \\
\text { Imagery and Mapping } \\
\text { Agency 1997) }\end{array}$ & \\
\hline $\begin{array}{l}\text { Proximity to existing } \\
\text { irrigation }\end{array}$ & $\begin{array}{l}\text { FAO Irrigation Scheme Map (Sirte Africa Large } \\
\text { Irrigation Map) }\end{array}$ & $\begin{array}{l}\text { Markets for inputs and outputs are already } \\
\text { developed, and farmers are familiar with } \\
\text { irrigation. }\end{array}$ \\
\hline Market access & Nelson (2008) travel time & $\begin{array}{l}\text { Adoption of irrigation relies on markets both } \\
\text { for securing inputs including equipment/facility } \\
\text { maintenance and for selling crop products. }\end{array}$ \\
\hline Surface runoff & $\begin{array}{l}\text { Fekete, Vörösmarty, and Grabs (2002), } \\
\text { Global Runoff Data Centre (GRDC) }\end{array}$ & $\begin{array}{l}\text { Small-scale irrigation technologies, such as } \\
\text { small reservoirs, depend on local runoff. }\end{array}$ \\
\hline
\end{tabular}

Source: Authors.

Table 3.2 Criteria for evaluating a pixel as entirely unsuitable for irrigation

\begin{tabular}{|c|c|c|}
\hline Criteria & Measurement cutoff & Explanation \\
\hline Topography (slope) & 10 degrees or greater & $\begin{array}{l}\text { Irrigation will, in most cases, be unfeasible for areas } \\
\text { with prohibitively steep slopes. }\end{array}$ \\
\hline $\begin{array}{l}\text { Groundwater } \\
\text { accessibility }\end{array}$ & None & Alternative sources of water may be available. \\
\hline $\begin{array}{l}\text { Distance to perennial } \\
\text { surface water }\end{array}$ & None & Alternative sources of water may be available. \\
\hline $\begin{array}{l}\text { Distance to main river } \\
\text { course }\end{array}$ & None & Alternative sources of water may be available. \\
\hline $\begin{array}{l}\text { Proximity to existing } \\
\text { irrigation }\end{array}$ & None & Alternative sources of water may be available. \\
\hline Market access & 3 hours' travel time or greater & $\begin{array}{l}\text { Excessive travel time to a major market indicates a } \\
\text { barrier to entry for small-scale farmers that may } \\
\text { make irrigation impractical if not infeasible. A cutoff } \\
\text { of } 3 \text { hours was chosen based on expert opinions } \\
\text { from the World Bank. }\end{array}$ \\
\hline Surface runoff data & None & Alternative sources of water may be available. \\
\hline Protected areas & Protected areas excluded & $\begin{array}{l}\text { Areas that are marked as protected and in which } \\
\text { agriculture is not allowed, as indicated by the UNEP } \\
\text { data, were excluded. }\end{array}$ \\
\hline Existing irrigation & Existing irrigation & $\begin{array}{l}\text { Areas with existing irrigation were considered } \\
\text { unsuitable for new irrigation projects. }\end{array}$ \\
\hline Urban areas & All urban areas excluded & $\begin{array}{l}\text { Urban irrigation (such as rainwater harvesting) was } \\
\text { not included in this analysis. }\end{array}$ \\
\hline
\end{tabular}

Source: Authors. 
Figure 3.2 Ex ante analysis scoring
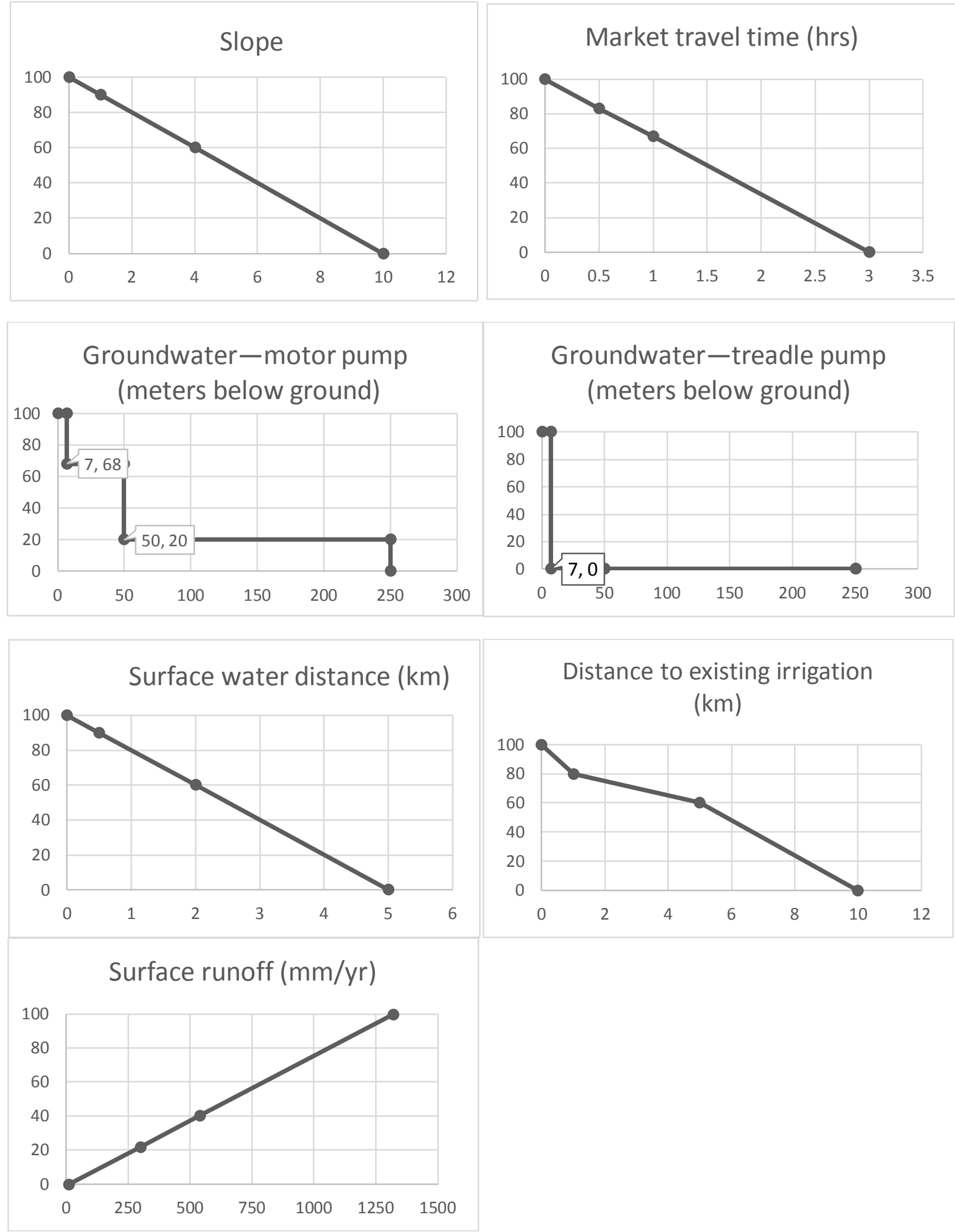

Source: Authors' calculation.

Note: Each panel displays the relevant score versus parameter function. 
In the ex ante suitability analysis, we divide the criteria parameters into three classes and use a linear interpolation within the classes to calculate the scores. Such a classification is similar to a stepwise function that gives us the flexibility of adjusting the threshold values after consulting with experts and stakeholders. The overall rating of the irrigation suitability is the average of the total scores for all applicable criteria. As both groundwater and surface water provide the same water resource for irrigation, we take the larger score of these two for calculating overall irrigation suitability. Thus, for motor pumps, the suitability score may be represented as follows:

$$
S=\frac{S_{1}+\max \left(S_{2}, S_{3}\right)+S_{4}+S_{5}}{4}
$$

where $\mathrm{S}$ is the irrigation suitability score (hereafter, ISS), $\mathrm{S}_{1}$ is the score for slope, $\mathrm{S}_{2}$ is the score for surface water access, $S_{3}$ is the score for groundwater access, $S_{4}$ is the score for ground distance to existing large-scale irrigation schemes, and $\mathrm{S}_{5}$ is the score for market access.

Because of data availability, the above suitability analysis is done on a $0.5 \mathrm{~km} \times 0.5 \mathrm{~km}$ grid. To maintain transparency and reduce further subjectivity in the analysis, each irrigation suitability score, which ranges from 0 to 100, is considered the percentage of area suitable for small-scale irrigation within that pixel. We believe this represents a reasonable assumption given that subpixel heterogeneity is not feasible under current data constraints. The ex ante suitability assessment may be further expanded to represent technology-specific suitability so long as appropriate data are available. As a first step in our analysis, we differentiated between motor pumps (able to reach deep groundwater), treadle pumps (able to use groundwater only down to $7 \mathrm{~m}$ ), and small reservoir technologies (not able to use groundwater but may instead use surface runoff).

The four figures below demonstrate that market access is the most constrictive constraint, as it is an exclusion criteria. Alternating the inclusion of various sources of water is also important for spatial coverage but may not have as large of an impact on the results as market access. The specific spatial patterns observed in Figures 3.3-3.5 may be broadly divided into three categories: the impact of distance to markets, the impact of access to groundwater, and the impact of access to surface runoff, respectively. The difference between Figure 3.4 and Figures 3.3 and 3.5 clearly demonstrates the restrictions imposed on the analysis by market constraints. The contrast between Figure 3.3 and Figure 3.6 demonstrates that restricting groundwater availability to $7 \mathrm{~m}$ depth uniformly lowers scores in northern Mozambique and Malawi, although Malawi appears to be less affected. A plausible explanation for this is that the majority of land area in Malawi is located within $10 \mathrm{~km}$ of an existing irrigation project. This means that in the absence of available groundwater, much of Malawi has access to alternative sources of water. These existing irrigation projects create the observed stippling of highly suitable areas throughout much of Mozambique. The effect would be the same across Malawi if irrigation projects were not as dense. The difference between Figure 3.5 and Figure 3.4 demonstrates that including surface runoff as a potential source of water does not improve the suitability of the more suitable areas but rather raises their minimum suitability, particularly across central and northern Mozambique. 
Figure 3.3 No market constraints

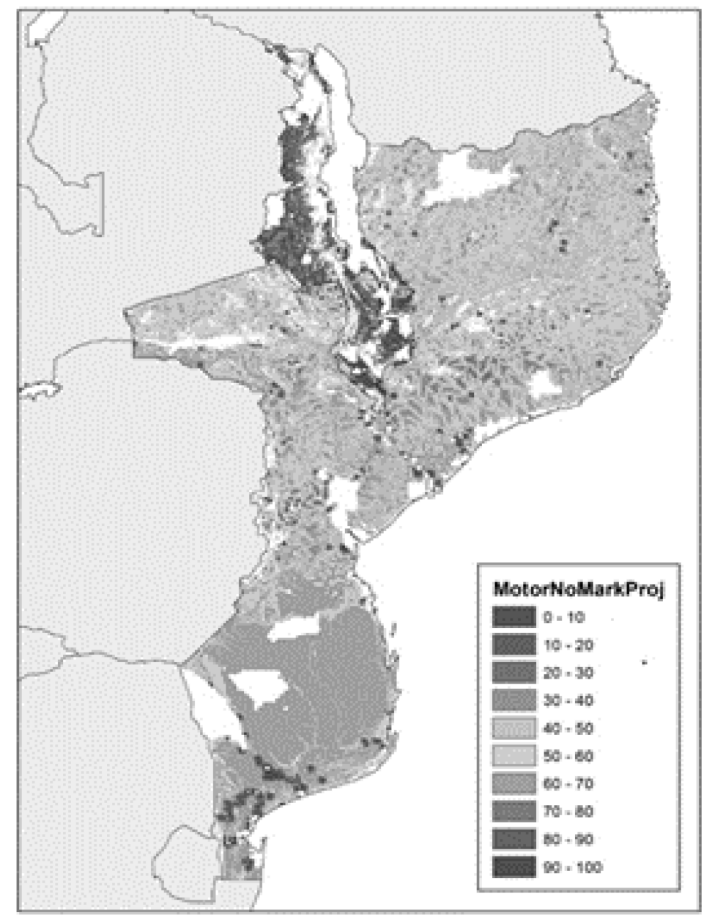

Source: Authors' calculation.

Figure 3.5 No market constraints, no groundwater, and surface runoff included

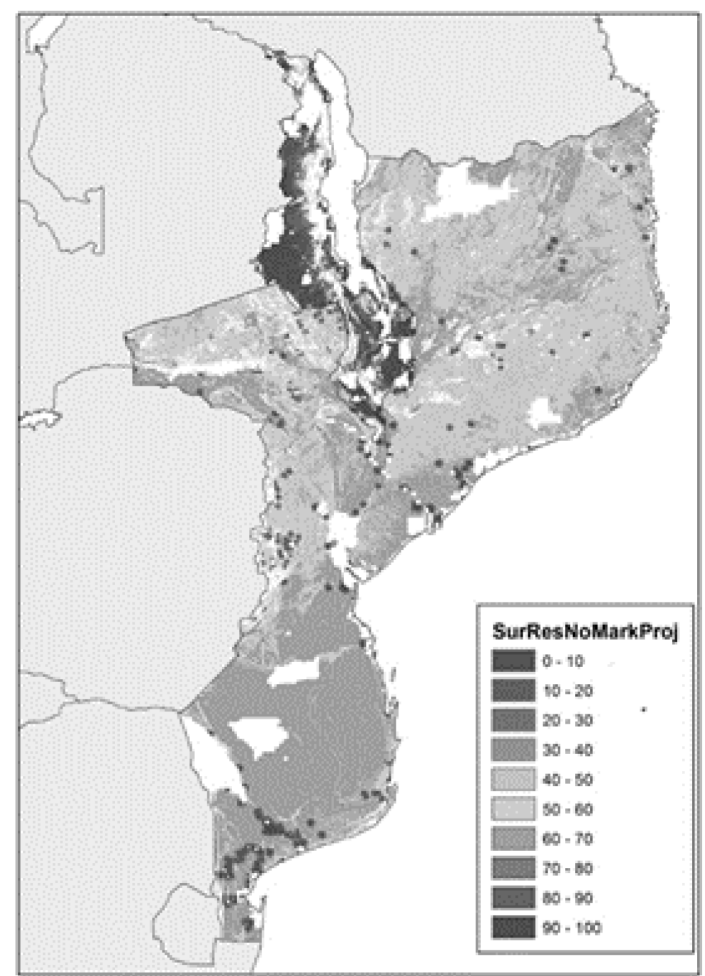

Source: Authors' calculation.
Figure 3.4 Full parameterization (includes all constraints)

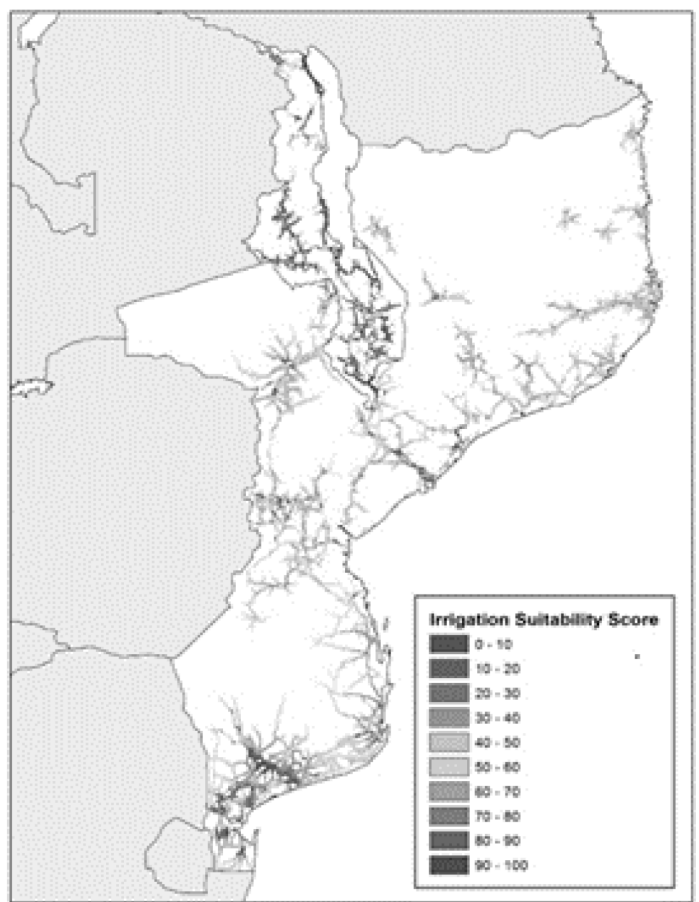

Source: Authors' calculation.

Figure 3.6 No market constraints, no runoff, and ground water available to $7 \mathrm{~m}$ below ground only

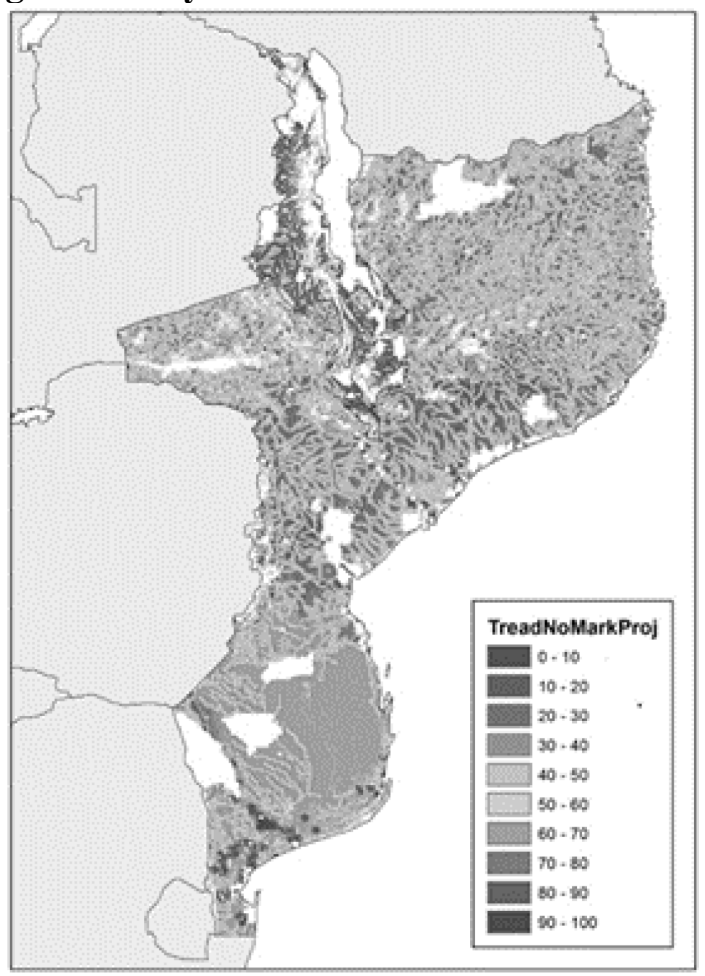

Source: Authors' calculation. 
To quantify the impact of the chosen scoring function of each parameter, a formal sensitivity analysis was conducted by shifting the bounds of each variable by $+/-10$ percent of the current variable scoring range. This means that, for example, if the current 0 score for market travel time is 180 minutes, then ranges of market travel time between 162 and 198 minutes were explored as the new 0 score in intervals of 1.8 minutes. This information was recorded for each variable and plotted in Figure 3.7. Market access was clearly the most sensitive parameter in the analysis, dominating the changes in mean suitability score across the domain of analysis, which is the entire SSA for this figure. The next most sensitive parameters are access to groundwater and land slope. Figure 3.7 can be updated as additional variables are added to the analysis.

Figure 3.7 Sensitivity analysis as a function of linear shifts in the scoring function of each variable for the fully parameterized motor-pump model for all of SSA

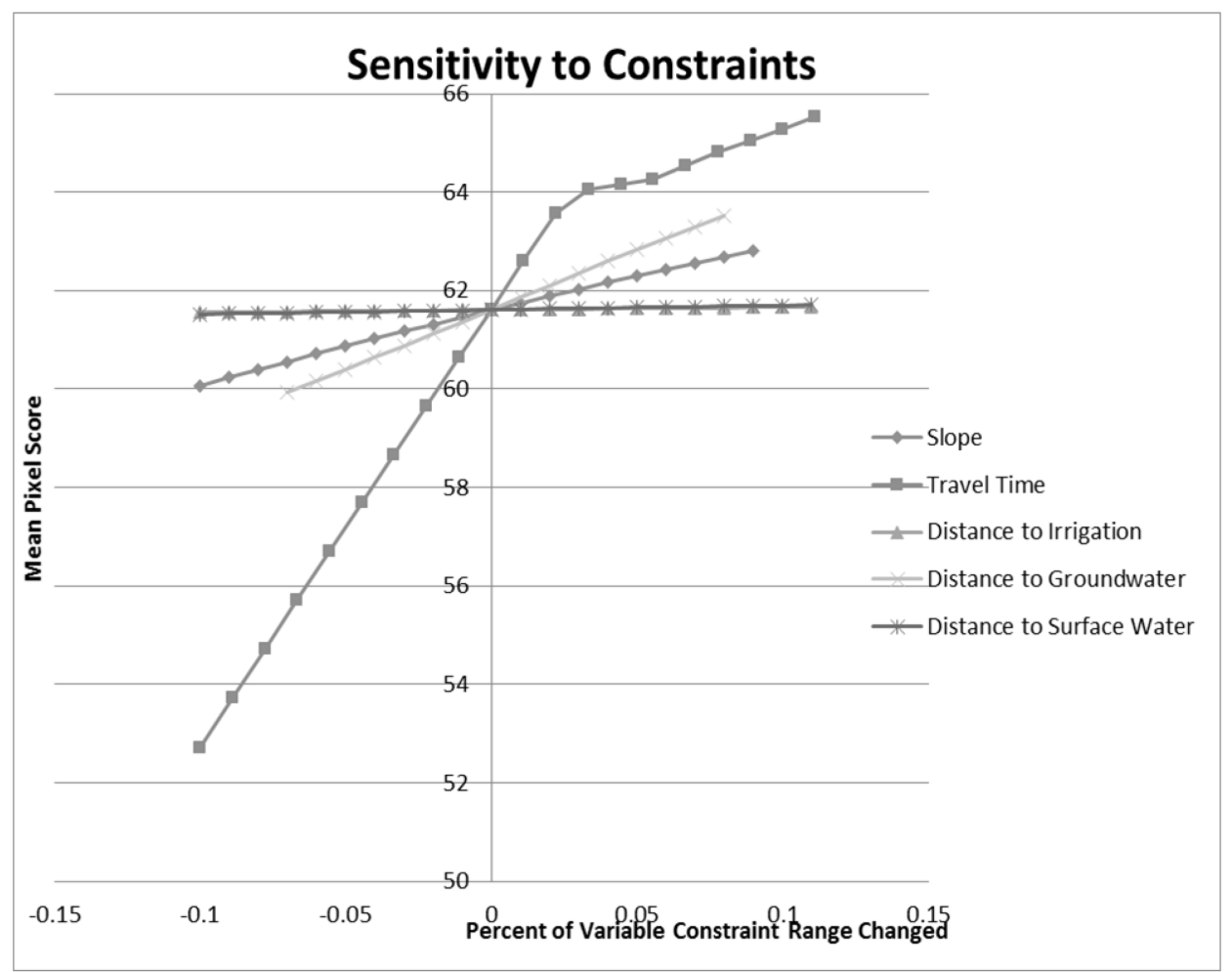

Source: Authors. 


\section{MICROLEVEL ANALYSIS OF NEXUS INTERVENTIONS}

At the microlevel, nexus interventions can be analyzed using qualitative or quantitative methods, or a combination of the two. Regarding nexus interventions specifically, no literature could be found that compares these two methods. Instead, we provide some generalizations. Quantitative methods at the microlevel are most often ex post impact evaluations in the form of household surveys. Quantitative results are expected to be statistically reliable, comparable, and generalizable, but they are inflexible and may omit important factors that could be revealed only qualitatively. Qualitative methods at the microlevel can be ex ante or ex post and can take the form of focus group discussions, in-depth interviews, or case studies. Qualitative results are precise and rich in detail but are difficult to compare and derive generalizations from. Qualitative data derived from interviews or focus group discussions would include individuals' perceptions of nexus interventions and their interrelated effects. Respondents may raise issues that would otherwise not be assessed in quantitative research. If an intervention were affecting a security in a way that had not been accounted for in the quantitative data, then qualitative research would likely reveal the oversight. In the context of analyzing nexus interventions, it is best to combine qualitative and quantitative methods to gain a comprehensive understanding of nexus effects at the microlevel. Ex ante qualitative methods, such as focus group discussions, should be used to narrow and confirm the relevance of an intervention. In an ex post analysis of the intervention, qualitative and quantitative methods complement each other and provide a full picture of effects.

Several challenges exist in the microeconomic analysis of nexus interventions. Many of these challenges are born from aggregation issues. Whether it be in extrapolating village-level data to the national level, assessing gender effects in technology adoption, or investigating income effects on child nutrition, improper aggregation can lead to erroneous research conclusions and misguided policy recommendations. The majority of microeconomic analyses are performed as ex post, impact evaluations. Detailed household-level data is collected in surveys that, because of their cost, are usually limited in scope to a sample size. This data are then used to make economywide models that are based on highly aggregated estimates (Simler and Nhate 2005). This is a constraint for policymakers to introduce welltargeted interventions. Targeting the rural poor in SSA is especially difficult because of low population densities and administrative constraints. The use of geographical targeting and poverty maps can help, but as Simler and Nhate (2005) find in Mozambique, poverty is not necessarily highly concentrated spatially. They observe that inequality between districts or administrative posts accounts for only about 20 percent of consumption inequality. The inference is that interventions using geographical targeting or poverty maps are prone to high levels of leakage to nonpoor and undercoverage of poor households in the nontargeted, less-poor areas.

One way to minimize detrimental aggregation effects when extrapolating household-level data is to use household modeling. As explained by Dorward et al. (2004), this entails developing the following: a typology for household types, that is, categorizing households by agroecological zone and socioeconomic characteristics; models that describe household behavior; and ties between the household model and a wider model of the informal rural economy. The household model accounts for seasonality in prices, labor, expenditures, savings, and so forth; income-generating activities; heterogeneity between households of a single zone in terms of land, labor, and capital; the effects of imperfect markets and transaction costs; and food-security objectives of consumers. The resulting informal rural economy model provides more detail on household challenges and opportunities than a CGE model and illustrates the interaction of households with nonfarm rural economies, but lacks the temporal and sectoral breadth of a CGE model (Dorward et al. 2004).

In analyzing the microeconomic effects of nexus interventions, it is important to include gender issues. In the area of extension services, for example, it has been found that having a female contact farmer for sustainable land management training improves adoption rates and the likelihood of knowledge spillovers in rural communities of Mozambique (Kondylis and Mueller 2012). Moreover, analysts need to take care in defining "women farmers" and their gender indicators (Ragasa 2012). The literature states 
that various gender indicators need to be collected for robust policy interventions, as female farmers are a heterogeneous group. Most studies, however, compare female- and male-headed households. Women farmers in male-headed households should not be ignored. Furthermore, there should be a distinction between de facto and de jure female-headed households. In determining factors that that affect technology adoption and income, studies should take into account the fact that female-headed households are generally smaller and have less access to resources. Lastly, interaction of gender with other demographic characteristics needs to be included in analysis (Ragasa 2012; Doss 1999; Doss and Morris 2001; Quisumbing and Pandolfelli 2009; Peterman, Behrman, and Quisumbing 2010). Failure to address these methodological issues could result in ineffective targeting and faulty policy recommendations (Ragasa 2012; Doss 1999; Doss and Morris 2001; Quisumbing and Pandolfelli 2009). Further aggregation challenges can occur when aggregating individuals into groups. For example, in the area of child nutrition in Mozambique, household income and mother's education have different effects on child nutrition indicators depending on the child's age (Sahn and Alderman 1997). Aggregating children into overly broad age groups, as is too often done, camouflages age-specific patterns and misrepresents impacts of income growth and nutrition education initiatives.

When determining the utility of nexus interventions, it is paramount to select appropriate outcome variables. In analyzing policy impacts on food insecurity and malnutrition in developing countries, much work has been done on calorie consumption effects, but micronutrient effects have largely been neglected. For example, Malawi's FISP has been relatively successful in increasing maize consumption (the local high-calorie staple), but it is unclear how the program has affected nutrient deficiencies (Pauw, Ecker, and Mazunda 2011). The literature finds that the battle against nutrient deficiencies would be better won through income-growth policies rather than input subsidies. Food price regulations in SSA are not only economically ineffective but can be damaging in the long run (Ecker and Qaim 2011; Bates 1981; Lipton 1977). Because of differing price elasticities of food demand and micronutrient demand in Malawi, Ecker and Qaim (2011) recommend income-related policies as an alternative to food production input subsidies such as FISP because they are less likely to distort markets and more likely to improve micronutrient consumption. Access to health and education improve with incomes (Anand and Ravallion 1993). If income-growth interventions (such as cash transfers and employment programs) are not feasible, an additional alternative would be to promote staple food biofortification (Qaim, Stein, and Meenakshi 2007).

The extent to which the utility of nexus interventions has been maximized at the microlevel is difficult to determine due to the inherently interwoven nature of related improvements and trade-offs and their inseparability at the household level. The availability of irrigation could improve food availability for a household by increasing crop yields, or it could reduce food availability if the household uses the irrigation to specialize in a cash crop. Within a village, increased irrigation could cause disparity between landholders and the landless and therefore detract from the community drinking water supply. Anecdotal evidence from Malawi suggests that food security and improved household welfare may be damaging to energy security: As farmers gain wealth, they upgrade their housing from straw and clay huts to mud brick buildings. The production of these bricks requires large quantities of firewood and is a major contributor to deforestation. Such trade-offs at the microlevel could be analyzed qualitatively but could prove difficult to analyze quantitatively.

\section{Secondary Data Analysis of FEW Nexus Patterns in Malawi and Mozambique}

Below, descriptive statistics and econometric analyses are applied to investigate patterns of the FEW nexus in Malawi and Mozambique. In particular, probit analyses examine the drivers of adoption of soil fertility management practices, type of cooking energy used, and irrigation (hereafter, FEW technologies). We assume that the probability to adopt FEW technologies is given by the following relationship:

$$
\mathrm{P}(\mathbf{y}=1 \mid \mathbf{x})=\mathrm{f}\left(\beta_{0}+\beta_{\mathbf{x}}\right)
$$


where $\mathrm{f}(\mathrm{z})$ is normally distributed with a probability density function of

$$
\frac{1}{\sigma \sqrt{2 \pi}} \exp \left(-\frac{(x-\mu)^{2}}{2 \sigma^{2}}\right)
$$

$\mathbf{x}$ is a vector containing covariates of drivers influencing the adoption of a FEW technology, $\mathrm{p} ; \mu$ is the mean of $\mathrm{x}_{\mathrm{i}} ; \sigma$ is the standard deviation of $\mathrm{x}_{\mathrm{i}}$; and $\beta_{\mathrm{i}}$ are coefficients associated with the corresponding covariate $i$.

Household-level capital endowment, land tenure rights, and village-level biophysical and socioeconomic characteristics are major drivers of the adoption of soil fertility management, irrigation, and use of energy sources (Reardon and Vosti 1996; Carney 1998), including natural capital, that is, the quantity and quality of natural resources such as land, water, forests, land investments, and ecosystem services therein; financial capital, that is, access to credit, savings, and income; social capital, that is, norms, values, cooperation, and trust that exist among community members that result in beneficial outcomes (Lin 2001; Pearson, Carr, and Shaw 2008); and human capital, that is, stock of family labor, human knowledge, and skills. The expected signs of the covariates are summarized in Table 4.1. We expect that natural capital will enhance the adoption of inorganic fertilizer as farmers are likely to apply fertilizer on plots with relatively good fertility to obtain maximum returns to fertilizer (Nkonya et al. 2008); however, the inverse relationship of farm size and productivity (Feder 1985; Lamb 2003) suggests that farmers with a large farm area are less likely to apply fertilizer than those with a smaller farm size. On the other hand, large farm size is likely to increase the probability of acquiring irrigation equipment, infrastructure, or both and of using improved cookstoves (ICSs), as they are expensive. Land investments, such as agroforestry, are likely to increase the probability of applying fertilizer. Because tobacco producers are wealthier than nontobacco producers (Orr 2000), we expect them to be more like to apply fertilizer. Likewise, greater physical capital and income are expected to positively influence the adoption of chemical fertilizer, irrigation, and ICS. Wealthier farmers' opportunity costs are higher, and therefore they are less likely to adopt labor-intensive management practices such as manure application. Social capital is expected to positively influence adoption of FEW technologies because it could help farmers gain access to rural services and other productive and marketing services and address other constraints. According to De Soto (2000), farmers with secure land tenure are expected to have long-term investments, such as irrigation infrastructure and manure application. However, farmers with insecure land tenure may also invest more in fertilizer and other inputs with short-term high returns. Land tenure may not affect directly energy sources given that this is a homestead investment, yet it may indirectly affect the choice of energy sources due to its impacts on income. Access to rural services and household human capital are generally expected to increase adoption of FEW technologies. However, access to rural services and higher education could increase farmers' opportunity costs and there reduce the propensity to adopt labor-intensive technologies such as manure. 
Table 4.1 Independent variables in the binary choice model and their expected signs

\begin{tabular}{|c|c|c|c|c|c|c|}
\hline \multirow[b]{2}{*}{ Variable } & \multirow[b]{2}{*}{ Fertilizer } & \multirow[b]{2}{*}{ Manure } & \multirow[b]{2}{*}{ Irrigation } & \multicolumn{3}{|c|}{$\begin{array}{l}\text { Data available? } \\
(\text { yes }=1, \text { no }=0)\end{array}$} \\
\hline & & & & $\begin{array}{l}\text { Improved } \\
\text { cookstove }\end{array}$ & Malawi & Mozambique \\
\hline \multicolumn{7}{|l|}{ Natural capital } \\
\hline Farm size & - & + & + & + & 1 & 1 \\
\hline $\begin{array}{l}\text { Land investment on farm dummies } \\
(\text { yes }=1, \text { no }=0)\end{array}$ & + & $+1-$ & $+1-$ & - & 1 & 1 \\
\hline Grow tobacco & + & - & + & + & 1 & 1 \\
\hline \multicolumn{7}{|l|}{ Physical capital } \\
\hline Own livestock & $-1+$ & + & + & $-1+$ & 1 & 1 \\
\hline Value of buildings & + & + & + & + & 1 & 1 \\
\hline Value of agricultural equipment & + & + & + & + & 1 & 1 \\
\hline \multicolumn{7}{|l|}{ Human capital } \\
\hline \multicolumn{7}{|l|}{$\begin{array}{l}\text { Level of formal education of } \\
\text { household (compare no formal } \\
\text { education) }\end{array}$} \\
\hline Primary & + & + & + & + & 1 & 1 \\
\hline Secondary & + & + & + & + & 1 & 1 \\
\hline Postsecondary & + & + & + & + & 1 & 1 \\
\hline $\begin{array}{l}\text { Primary activity of household head } \\
\text { (compare crop production) }\end{array}$ & & & & & 1 & 1 \\
\hline Nonfarm activity & $-1+$ & - & - & + & 1 & 1 \\
\hline Livestock & - & + & - & - & 1 & 1 \\
\hline $\begin{array}{l}\text { Sex of household head }(\text { male }=1 \text {, } \\
\text { female }=0 \text { ) }\end{array}$ & + & + & + & + & 1 & 1 \\
\hline Household size & - & + & + & - & 1 & 1 \\
\hline \multicolumn{7}{|l|}{ Access to rural services } \\
\hline $\begin{array}{l}\text { Received education aid (for } \\
\text { example school feeding program) }\end{array}$ & - & - & - & - & 1 & 1 \\
\hline Received food aid & - & - & - & - & 1 & 1 \\
\hline Received fertilizer subsidy & + & $-1+$ & $-1+$ & + & 1 & 1 \\
\hline Distance to all-weather road $(\mathrm{km})$ & - & + & - & - & 1 & 1 \\
\hline Received extension visits. & + & + & + & + & 1 & 1 \\
\hline $\begin{array}{l}\text { Method of land acquisition } \\
\text { (compare inheritance) }\end{array}$ & $-1+$ & + & $+/-$ & $-1+$ & 1 & 1 \\
\hline
\end{tabular}

Source: Authors.

A number of variables are endogenous. Two-stage least approach (2SLS) gives consistent and unbiased coefficients if instrumental variables (IV) are not correlated with the model's error term (Davidson and MacKinnon 2004). However, data in both countries did not provide good instruments, so we estimated both structural and reduced models to check for robustness of the coefficients. The continuous variables were checked for normality and skewness and were found to have fairly normal distribution. Multicollinearity was also checked by the variance inflation factor (VIF), and results indicate that it was not a concern because the VIF is less than 10 (Mukherjee, White, and Wuyts 1998). To control for heteroscedasticity, we estimate robust maximum likelihood coefficients. The empirical model is dictated by data availability. Variables in Table 4.1 were collected in Malawi from the integrated household survey of 2010/2011 and in Mozambique from the 2008 household budget survey. However, some key data, such as irrigation, were not available from the Mozambique household budget survey. To 
address this gap, we obtained data from the 2008 agricultural household survey, which was also missing some key data needs, such as the source of cooking energy. Below, we present descriptive results and econometric results for Malawi and then Mozambique. Table 4.2 reports basic characteristics of rural and urban households in Malawi. Malawian farmers are largely smallholder producers with an average farm size of only 3.7 acres among rural households. The average farm size of female-headed households is only half of that for male-headed households. This is typical for SSA and underlies the challenges of female-headed households in resource management. The most common land tenure is customary, in which the method of land acquisition is inheritance.

Table 4.2 Land tenure in Malawi

\begin{tabular}{llllll}
\hline Variable & Malawi & Urban & Rural & Male & Female \\
\hline Farm size (acres) & $\mathbf{3 . 6}$ & $\mathbf{1 . 2}$ & $\mathbf{3 . 7}$ & $\mathbf{4 . 1}$ & $\mathbf{2 . 0}$ \\
\hline \multicolumn{2}{l}{ Land tenure/method of land acquisition (\%) } & & & \\
\hline Inherited & 78.5 & 55.0 & 79.7 & 77.8 & 80.5 \\
Granted by local leaders & 9.1 & 5.4 & 9.3 & 8.8 & 10.0 \\
Rented in & 6.9 & 17.6 & 6.4 & 7.6 & 4.9 \\
Purchased & 2.6 & 7.7 & 2.4 & 2.9 & 2.0 \\
Other methods & 2.8 & 14.3 & 2.3 & 2.9 & 2.6 \\
\hline Sex of land owner & & & & & \\
\hline Female & 35.1 & 25.5 & 35.5 & 21.3 & 74.3 \\
Male & 34.6 & 26.3 & 35.0 & 45.1 & 4.5 \\
Not owned & 19.1 & 37.3 & 18.2 & 19.4 & 18.1 \\
Jointly owned & 11.3 & 10.8 & 11.3 & 14.2 & 3.1 \\
\hline
\end{tabular}

Source: Malawi integrated household survey 2010/2011 (NS0 2012).

As expected, a large share of farmers (61 percent) apply inorganic fertilizer and only a small share apply organic inputs (see Table 4.3). Holden and Lunduka (2012b) observed that in Malawi, the application of inorganic fertilizer does not crowd out the use of organic inputs. Thus, the small share of farmers using organic inputs seems to be related to extension messages. This is supported by findings in a study that interviewed agricultural extension agents in Uganda and Nigeria and revealed that only a small share of extension agents provided advisory services on organic inputs (AGRA 2014; Nkonya et al. 2014). Likewise, the adoption rate of improved maize seed is high, which likely stems from subsidies under FISP, which include improved seeds. Very few households use irrigation on their farms, just 0.5 percent (Table 4.3), which is comparable to the percentage ( 0.6 percent) of cropland under irrigation in SSA (AGRA 2014). Despite Malawi's development and promotion of ICSs, use of nonwood as a cooking energy source is quite low among rural households. About 41 percent of rural households are food insecure, which is consistent with Figure 2.3 and again shows that Malawi has not achieved food security despite large investments in subsidies. 
Table 4.3 Characteristics of input use and enterprises in Malawi

\begin{tabular}{lllll}
\hline Variable & Malawi & Rural & Male & Female \\
\hline Inorganic fertilizer & 61.3 & 61.0 & 61.9 & 59.8 \\
Organic fertilizer & 11.5 & 11.3 & 11.7 & 10.9 \\
Improved maize seeds & 31.6 & 30.7 & - & - \\
Recycled maize seeds & 4.0 & 3.7 & 4.0 & 3.9 \\
Irrigation & 0.5 & 0.5 & 0.6 & 0.3 \\
Tobacco & 8.5 & 8.9 & 10.4 & 3.3 \\
Access to safe potable water & 78.7 & 78.7 & - & - \\
\hline Source of cooking energy & & & & \\
\hline Solid bioenergy & 97.4 & 99.3 & - & - \\
Electricity & 2.5 & 0.6 & - & - \\
Charcoal & 8.9 & 2.3 & - & - \\
Crop residues/sawdust/animal waste & 0.8 & 0.9 & - & - \\
Food insecure (inadequate food) & 38.3 & 40.9 & 35.8 & 46.3 \\
\hline
\end{tabular}

Source: Malawi integrated household survey 2010/2011 (NSO 2012).

Notes: Data are from 2011. Percent of energy sources used add to more than 100 percent because some households use more than one source of cooking energy.

We now turn to the econometric results from the probit analyses. As expected, proximity to roads, access to credit, and participation in agricultural marketing have a strong and favorable impact on the adoption of irrigation and both inorganic and organic fertilizer. Likewise, farmers who acquired land through purchase are more likely to use irrigation and adopt soil fertility management practices compared with those who acquired land through inheritance. These findings demonstrate the importance of farmer participation in markets and the key role of rural services for the adoption of irrigation and soil fertility management practices (Barrett 2008). Surprisingly, access to agricultural extension services has a weak or no significant impact on the adoption of irrigation and soil fertility management practices. The weak impact of agricultural extension on adoption of inorganic fertilizer could be due to the widespread awareness of farmers resulting from fertilizer subsidy and other long-term food security government programs. The weak impact on irrigation is not surprising given that irrigation advisory services have generally been poor in SSA (Nkonya et al. 2014).

Controlling for income and wealth indicators, household size increases the propensity to use irrigation and soil fertility management practices, an aspect that could reflect household efforts to maximize productivity on their land. As expected, female-headed households are less likely to use irrigation, inorganic fertilizer, and organic fertilizer. This reflects their natural and social capital constraints that could lead to their failure to use these technologies. Secondary education by the household head has a negative impact on adoption of all three technologies, which could be explained by improved access to alternative livelihoods that could lead to a lower priority given to crop production. Lower adoption of manure could also be due to higher opportunity costs from more education. Likewise, rural households are more likely to use all three technologies compared with urban households. Consistent with the induced innovation theory (Boserup 1965), community population density increases the propensity to use fertilizer. However, population density does not have a significant impact on the adoption of organic inputs.

Consistent with results on adoption of irrigation of irrigation and soil fertility management practices, Table 4.4 shows that access to credit, participation in markets, having nonfarm activities or higher education of the household head, and proximity to roads reduces the propensity to use the traditional fuelwood. Higher education of the household head also increases the probability to use electricity and charcoal but reduces the probability to use paraffin (see Table 4.5). This further demonstrates the importance of access to rural services in achieving the virtuous FEW nexus. 
Table 4.4 Drivers of irrigation and fertilizer adoption in Malawi $(N=10,360)$

\begin{tabular}{|c|c|c|c|c|c|c|}
\hline \multirow{2}{*}{$\begin{array}{l}\text { Variable } \\
\text { Probit model type }\end{array}$} & \multicolumn{2}{|l|}{ Irrigation } & \multicolumn{2}{|c|}{ Inorganic fertilizer } & \multicolumn{2}{|c|}{ Organic fertilizer } \\
\hline & Structural & Reduced & Structural & Reduced & Structural & Reduced \\
\hline \multicolumn{7}{|l|}{ Access to rural services } \\
\hline Received credit & $0.168^{* * *}$ & & $0.204^{* *}$ & & $0.145^{* *}$ & \\
\hline Nonfarm is primary activity & 0.012 & & 0.004 & & $0.090^{*}$ & \\
\hline $\begin{array}{l}\text { Received extension services } \\
\text { Participated in agroforestry } \\
\text { programs }\end{array}$ & $\begin{array}{l}0.025 \\
0.021\end{array}$ & & $\begin{array}{l}0.057 \\
0.057\end{array}$ & & $\begin{array}{l}0.090^{*} \\
-0.036\end{array}$ & \\
\hline Participate in market & $0.222^{* * *}$ & & $0.349^{* * *}$ & & $0.263^{* * *}$ & \\
\hline Received food aid & $-0.102^{* *}$ & & 0.002 & & -0.048 & \\
\hline Received input vouchers & 0.262 & & 0.443 & & $0.685^{* *}$ & \\
\hline $\begin{array}{l}\text { Received cash transfer } \\
\text { Participated in education } \\
\text { program }\end{array}$ & $\begin{array}{l}0.151 \\
0.075 \\
\end{array}$ & & $\begin{array}{l}0.111 \\
0.092 \\
\end{array}$ & & $\begin{array}{l}0.728^{*} \\
0.031\end{array}$ & \\
\hline \multicolumn{7}{|l|}{ Human capital } \\
\hline $\begin{array}{l}\text { Grow tobacco } \\
\text { Ln(household head age, } \\
\text { years) }\end{array}$ & $\begin{array}{l}0.092^{*} \\
-0.167^{\star * \star}\end{array}$ & $-0.203^{* * *}$ & $\begin{array}{l}-0.009 \\
-0.254^{\star * *}\end{array}$ & $-0.289^{\star * *}$ & $\begin{array}{l}0.063 \\
-0.103\end{array}$ & $-0.150^{* *}$ \\
\hline Ln(household size) & $0.122^{* \star *}$ & $0.128^{* * *}$ & $0.154^{* * *}$ & $0.169^{* * *}$ & $0.168^{* * *}$ & $0.173^{* * *}$ \\
\hline Female-headed household & $-0.112^{* *}$ & $-0.142^{\star * *}$ & $-0.110^{* *}$ & $-0.133^{* *}$ & -0.054 & -0.073 \\
\hline Primary activity livestock & $0.138^{* * *}$ & $0.197^{* * *}$ & $0.189^{\star * *}$ & $0.263^{* * *}$ & $0.246^{* * *}$ & $0.309^{* * *}$ \\
\hline \multicolumn{7}{|c|}{ Level of education of household head (compare no formal education) } \\
\hline Primary education & -0.021 & 0.005 & 0.048 & $0.077^{*}$ & -0.056 & -0.02 \\
\hline Secondary education & $-0.190^{* *}$ & $-0.212^{* * *}$ & $-0.230^{* * *}$ & $-0.253^{* * *}$ & -0.049 & -0.078 \\
\hline Postsecondary education & -0.174 & -0.194 & -0.056 & -0.099 & -0.156 & -0.19 \\
\hline \multicolumn{7}{|c|}{ Land tenure/method of acquisition (compare customary) } \\
\hline Purchased & $2.408^{* * *}$ & $2.388^{* * *}$ & $1.543^{* * *}$ & $1.529 * * *$ & $1.384^{* * *}$ & $1.398^{* * *}$ \\
\hline Rented & $2.172^{* * *}$ & $2.155^{\star \star \star}$ & $1.672^{* *}$ & $1.657^{* * *}$ & $0.850^{* * *}$ & $0.855^{\star * *}$ \\
\hline Granted by local leaders & $2.393^{* * *}$ & $2.400^{* * *}$ & $1.262^{* * *}$ & $1.274^{* * *}$ & $1.248^{* * *}$ & $1.253^{* * *}$ \\
\hline Other acquisition methods & $-1.137^{* * *}$ & $-1.076^{* *}$ & 0.019 & 0.129 & -0.091 & -0.011 \\
\hline \multicolumn{7}{|c|}{ Expenditure quintile (compare low quintile) } \\
\hline Medium & -0.067 & -0.066 & 0.02 & 0.028 & -0.002 & 0.003 \\
\hline High & -0.045 & -0.029 & 0.064 & 0.085 & 0.006 & 0.031 \\
\hline Ln(community population) & -0.014 & -0.015 & $0.040^{* *}$ & $0.037^{* *}$ & 0.028 & 0.027 \\
\hline Ln(distance to city, km) & $-0.107^{* * *}$ & $-0.095^{\star * *}$ & $-0.138^{* * *}$ & $-0.120^{* * *}$ & $-0.199^{* * *}$ & $-0.186^{* * *}$ \\
\hline Rural area (compare urban) & $0.590^{* * *}$ & $0.660^{* * *}$ & $0.529^{* * *}$ & $0.620^{* * *}$ & $0.736^{* * *}$ & $0.801^{* * *}$ \\
\hline Constant & 0.01 & 0.082 & $-1.545^{\star \star *}$ & $-1.477^{\star \star \star}$ & $-2.040^{\star * *}$ & $-1.884^{* * *}$ \\
\hline
\end{tabular}

Source: Authors' calculations.

Note: $\quad *, * *$ and $* * *$ indicates $10 \%, 5 \%$ and $1 \%$ significance level, respectively. 
Table 4.5 Drivers of energy choice in rural Malawi $(N=9,462)$

\begin{tabular}{|c|c|c|c|c|c|c|c|c|}
\hline \multirow{2}{*}{$\begin{array}{l}\text { Variable } \\
\text { Probit model type }\end{array}$} & \multicolumn{2}{|c|}{ Charcoal } & \multicolumn{2}{|c|}{ Fuelwood } & \multicolumn{2}{|c|}{ Electricity } & \multicolumn{2}{|c|}{ Paraffin } \\
\hline & Structural & Reduced & Structural & Reduced & Structural & Reduced & Structural & Reduced \\
\hline \multicolumn{9}{|l|}{ Access to rural services } \\
\hline Received credit & -0.097 & & $-0.310^{* \star *}$ & & -0.08 & & $0.147^{*}$ & \\
\hline Nonfarm is primary activity & -0.138 & & $-0.228^{* * *}$ & & 0.022 & & -0.017 & \\
\hline Received extension services & -0.017 & & $0.147^{\star *}$ & & -0.014 & & $0.140^{* * *}$ & \\
\hline Participated in agroforestry program & $s-0.082$ & & $-0.162^{* *}$ & & $-0.267^{* * *}$ & & $-0.101^{*}$ & \\
\hline Participated in market & 0.049 & & $-0.262^{* * *}$ & & 0.024 & & -0.049 & \\
\hline Received food aid & -0.102 & & -0.11 & & $0.170^{* *}$ & & $-0.214^{* *}$ & \\
\hline Received input vouchers & $-3.733^{* * *}$ & & $3.891^{* * *}$ & & $-3.659^{* * *}$ & & 0.274 & \\
\hline Received cash transfer & $-3.243^{\star \star \star}$ & & $3.695^{\star * *}$ & & $-3.812^{\star * \star}$ & & 0.263 & \\
\hline Participated in education program & $-4.164^{\star \star *}$ & & -0.294 & & $-4.263^{* * *}$ & & 0.116 & \\
\hline \multicolumn{9}{|l|}{ Human capital } \\
\hline Grow tobacco & $-0.920^{* * *}$ & & $0.573^{* * *}$ & & $-0.336^{* * *}$ & & $0.206^{* *}$ & \\
\hline Ln(household head age, years) & $-0.249^{*}$ & $-0.254^{* *}$ & $0.140^{*}$ & $0.160^{*}$ & 0.095 & 0.057 & $0.471^{* * *}$ & $0.434^{* * *}$ \\
\hline Ln(household size) & $-0.345^{\star * \star}$ & $-0.354^{* \star *}$ & $0.258^{* * *}$ & $0.253^{* * *}$ & -0.084 & -0.077 & 0.073 & 0.071 \\
\hline Female-headed household & -0.201 & -0.186 & 0.075 & 0.027 & -0.059 & -0.038 & $0.435^{\star * *}$ & $0.401^{* * *}$ \\
\hline Primary activity livestock & $-0.227^{* *}$ & $-0.294^{* * *}$ & 0.075 & 0.03 & 0.064 & 0.014 & $-0.241^{* * *}$ & $-0.209^{* * *}$ \\
\hline \multicolumn{9}{|c|}{ Level of education of household head (compare no formal education) } \\
\hline Primary education & $0.295^{* * *}$ & $0.278^{* * *}$ & $-0.130^{*}$ & $-0.130^{* *}$ & $0.297^{* * *}$ & $0.264^{* * *}$ & $-0.301^{* * *}$ & $-0.276^{* * *}$ \\
\hline Secondary education & $0.738^{* * *}$ & $0.753^{* * *}$ & $-0.656^{\star * \star}$ & $-0.659^{* * *}$ & $0.636^{* * *}$ & $0.633^{* * *}$ & $-0.454^{* *}$ & $-0.463^{* *}$ \\
\hline Postsecondary education & $0.815^{\star * *}$ & $0.806^{* * *}$ & $-1.014^{* * *}$ & $-0.968^{* * *}$ & $1.130^{* * *}$ & $1.117^{* * *}$ & $-3.523^{* * *}$ & $-3.593^{* * *}$ \\
\hline \multicolumn{9}{|c|}{ Land tenure/method of acquisition (compare customary) } \\
\hline Purchased & $-4.036^{* * *}$ & $-4.114^{* * *}$ & $4.192^{* * *}$ & $3.439^{* * *}$ & $-3.837^{* * *}$ & $-3.760^{* * *}$ & $-3.945^{* * *}$ & $-3.998^{* * *}$ \\
\hline Rented & 0.154 & 0.129 & $-0.519^{* *}$ & $-0.590^{* * *}$ & 0.321 & 0.36 & $-3.685^{\star \star *}$ & $-3.694^{\star * *}$ \\
\hline Granted by local leaders & $-4.537^{* * *}$ & $-4.615^{* * *}$ & 0.245 & 0.256 & $-4.875^{\star \star \star}$ & $-4.993^{* * *}$ & -0.059 & -0.031 \\
\hline Other acquisition methods & $3.546^{* * *}$ & $3.562^{* * *}$ & 0.397 & 0.222 & -0.229 & -0.293 & $3.771^{* * *}$ & $3.864^{* * *}$ \\
\hline \multicolumn{9}{|c|}{ Expenditure quintile (compare low quintile) } \\
\hline Medium & $0.463^{* *}$ & $0.441^{* *}$ & 0.085 & 0.064 & 0.013 & -0.002 & $-0.429^{* * *}$ & $-0.422^{* * *}$ \\
\hline High & $1.249^{* * *}$ & $1.211^{* * *}$ & $-0.416^{* * *}$ & $-0.407^{* * *}$ & $0.624^{* * *}$ & $0.613^{* * *}$ & $-0.720^{* * *}$ & $-0.697^{* * *}$ \\
\hline Ln(community population) & $0.130^{* * *}$ & $0.118^{* * *}$ & $-0.129^{\star \star \star}$ & $-0.119^{\star * \star}$ & 0.029 & 0.029 & $-0.113^{* \star *}$ & $-0.116^{\star * *}$ \\
\hline Ln(distance to city, km) & $-0.154^{* \star *}$ & $-0.168^{* * *}$ & $0.314^{* * *}$ & $0.333^{* * *}$ & $-0.150^{* * *}$ & $-0.170^{\star * *}$ & $0.138^{* * *}$ & $0.135^{* * *}$ \\
\hline Rural area (compare urban) & $-5.494^{* * *}$ & $-5.425^{\star * \star}$ & 0.834 & 0.588 & $-2.032^{* * \star}$ & $-1.793^{* * *}$ & $-7.009^{* * *}$ & $-6.920^{* * *}$ \\
\hline Constant & & & & & & & & \\
\hline
\end{tabular}

Source: Authors' calculations.

Note: $\quad *, * *$ and $* * *$ indicates $10 \%, 5 \%$ and $1 \%$ significance level, respectively. 
The adoption rate of fertilizer in Mozambique is much lower than in Malawi. Only 11 percent of farmers at the national level and 15 percent in Tete province ${ }^{7}$ (located in northwestern Mozambique and bordering Malawi) use fertilizer (Figure 4.1) compared with more than 60 percent in Malawi (Table 4.3). This difference has several possible explanations, including the impact of fertilizer subsidies in Malawi and the lack of such input support in Mozambique. In addition, production of maize - a crop that receives the largest share of fertilizer in SSA (FAO 2006) - in Malawi is more pronounced than in Mozambique. However, Tete has a greater adoption rate of fertilizer than expected. About 12 percent of households in Mozambique and 15 percent in Tete use irrigation. This is higher than in Malawi, where less than 1 percent of households use irrigation. Part of this large difference is the much drier environment in large parts of Mozambique that require irrigation. As is the case in Malawi, the majority (96 percent) of households in rural Mozambique use woodfuel. Table 4.6 provides details on the energy sources used in Mozambique and in Angonia district in Tete, showing that other sources of energy are paraffin, electricity, and charcoal. This further shows the need to increase investment in the development of cooking energy sources including ICSs.

\section{Figure 4.1 Adoption of soil fertility management and irrigation in Mozambique}

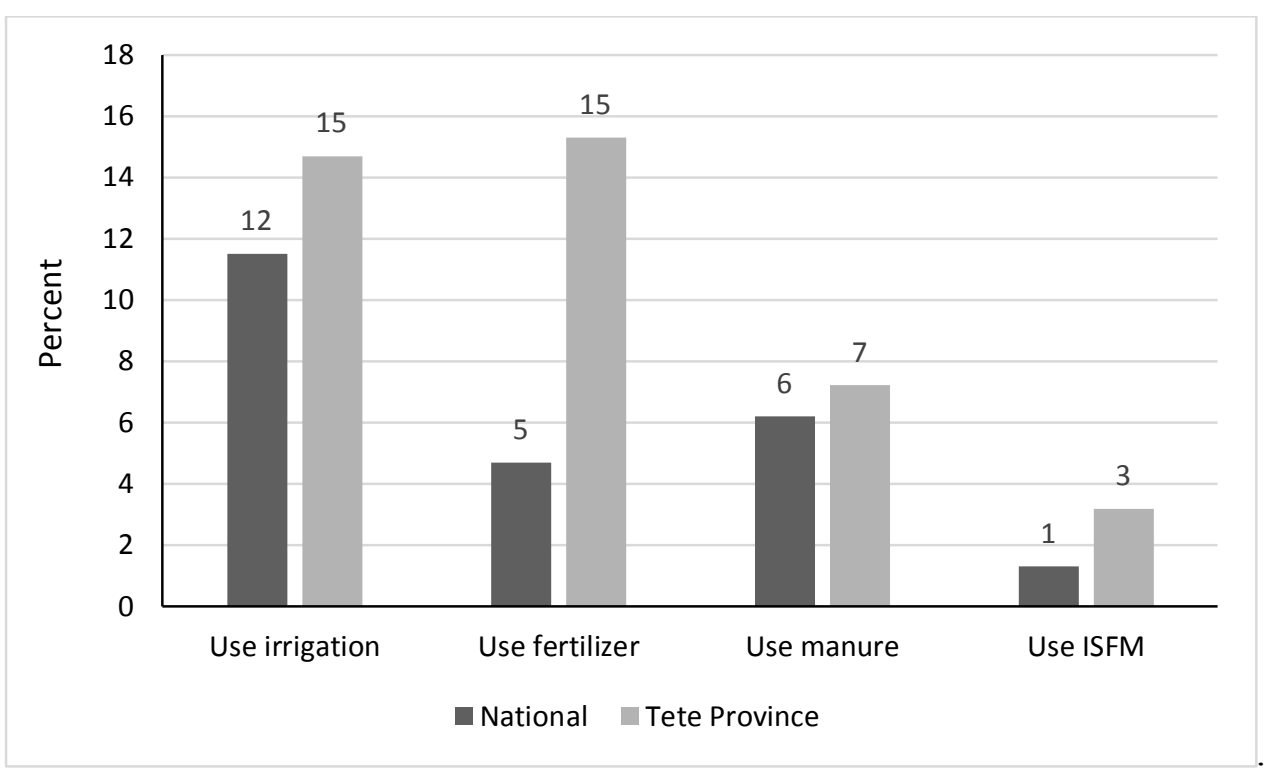

Source: National Agricultural Survey 2008 (MINAG 2009).

Table 4.6 Sources of cooking energy in Mozambique (in percentage, using source)

\begin{tabular}{lcccc}
\hline & \multicolumn{2}{c}{ National } & \multicolumn{2}{c}{ Angonia district } \\
\hline Energy source & $\begin{array}{c}\text { Rural } \\
(\mathbf{N = 1 4 , 0 4 1 )}\end{array}$ & $\begin{array}{c}\text { Urban } \\
\mathbf{( N = 5 , 2 2 3 )}\end{array}$ & $\begin{array}{c}\text { Rural } \\
\mathbf{( N = 6 2 1 )}\end{array}$ & $\begin{array}{c}\text { Urban } \\
\mathbf{( N = 4 4 3 )}\end{array}$ \\
\hline Electricity & 0.1 & 1.6 & 0.2 & 1.1 \\
Gas & 0.1 & 6.6 & 0 & 4.9 \\
Paraffin & 0.6 & 0.4 & 0 & 1.1 \\
Charcoal & 1.6 & 42.9 & 1.3 & 41.7 \\
Coal & 0.3 & 1.2 & 0.5 & 0 \\
Wood & 96.3 & 46.9 & 95.8 & 50.6 \\
\hline
\end{tabular}

Source: Inquérito Sobre Orcamento Familiar 2008/2009 (INE 2010).

\footnotetext{
${ }^{7}$ We focus on Tete Province and on Angonia district specifically due to an ongoing project there on the FEW nexus.
} 
We now examine results from the econometric analyses for data from Mozambique. Similar to findings in Malawi, growing tobacco and having a higher income increase the propensity to use fertilizer in Mozambique (Table 4.7). The results also show that having a bank account and livestock increase the probability of using fertilizer. As expected and consistent with Malawi, women are less likely to use fertilizer. Surprisingly, ownership of a television set or radio, access to market, and higher education of the household head has either a negative impact or no impact on the adoption of fertilizer. In general, the favorable impacts of access to rural services found in Malawi are not reflected in the findings from Mozambique. This may be due to the generally poor rural services there as well as the unavailability of key data, such as access to extension services, which could lead to omission bias and poor results. The probability to use electricity or charcoal decreases for tobaccogrowing farmers (Table 4.7). As expected and consistent with results from Malawi, urban households, households closer to roads, households with higher income, and households whose heads have completed more education are more likely to use charcoal or electricity. Tobacco growers, livestock keepers, postsecondary education, and age of household head reduce the propensity to use paraffin. Similar to the results for the adoption of fertilizer, other important data on rural services are unavailable, which could introduce omission bias.

Table 4.7 Drivers of fertilizer use in Mozambique

\begin{tabular}{|c|c|c|c|c|}
\hline \multirow[b]{3}{*}{ Human capital } & \multicolumn{2}{|c|}{ National $(\mathrm{N}=10,798)$} & \multicolumn{2}{|c|}{ Rural $(\mathrm{N}=5,588)$} \\
\hline & Structural & Reduced & Structural & Reduced \\
\hline & & & & \\
\hline Grow tobacco & $12.447^{* * *}$ & & $11.935^{\star \star *}$ & \\
\hline Ln(hours doing nonfarm activities) & -0.282 & & -0.263 & \\
\hline Primary activity is livestock & $21.188^{\star * \star}$ & $8.003^{* * *}$ & $20.667^{\star * \star}$ & $5.925^{\star * *}$ \\
\hline Ln(household size) & 0.377 & $0.634^{* *}$ & 0.287 & $0.513^{*}$ \\
\hline Ln(age household head) & $-1.109^{\star *}$ & $-0.669^{\star * *}$ & $-0.861^{* *}$ & $-0.504^{* * *}$ \\
\hline Female-headed household & $-4.890^{* * *}$ & -0.269 & $-4.546^{\star * \star}$ & -0.269 \\
\hline \multicolumn{5}{|c|}{ Level of formal education of household head (compare no formal education) } \\
\hline Primary education & $-9.751^{\star * \star}$ & -0.24 & $-9.246^{\star \star \star}$ & -0.229 \\
\hline Secondary education & -0.307 & 0.425 & -0.137 & 0.443 \\
\hline Postsecondary education & -4.661 & $-3.177^{\star * *}$ & -4.51 & -3.348 \\
\hline \multicolumn{5}{|l|}{ Financial capital } \\
\hline Have bank account & $1.298^{* * *}$ & & $1.078^{* * *}$ & \\
\hline \multicolumn{5}{|c|}{ Income group (compare low expenditure quintile) } \\
\hline Middle expenditure quintile & $14.5999^{* * *}$ & $5.654^{* * *}$ & $14.437^{\star * \star}$ & $3.592^{* * *}$ \\
\hline Highest expenditure quintile & $14.685^{\star \star \star}$ & $5.550^{* * *}$ & $14.533^{* * *}$ & $3.507^{* * *}$ \\
\hline \multicolumn{5}{|l|}{ Access to rural services } \\
\hline Own radio & -0.531 & -0.203 & -0.516 & -0.196 \\
\hline Own television & $-16.787^{\star * *}$ & $-6.308^{\star * *}$ & -4.503 & $-3.728^{\star * *}$ \\
\hline Ln(time to market) & -0.265 & -0.178 & -0.262 & -0.184 \\
\hline Reside in urban area & $-8.359^{* * *}$ & $-4.495^{\star * *}$ & - & - \\
\hline Constant & $-13.207^{* * *}$ & $-6.660^{\star * *}$ & $-13.777^{\star \star *}$ & $-4.976^{* * *}$ \\
\hline
\end{tabular}

Source: Authors' calculations.

Note: $\quad *, * *$ and $* * *$ indicates $10 \%, 5 \%$ and $1 \%$ significance level, respectively.

Both human capital (household size and education) and physical capital endowment positively influence the adoption of irrigation. The results suggest that irrigation development and access is strongly driven by capital endowment. Additionally, farmers tend to complement soil fertility improvement with irrigation - an area that strongly supports farmer behavior to ensure greater 
returns on investment. The results imply the need for organizing farmers into water user associations to pool resources together and overcome other constraints that could hamper resource-poor farmers from investing into irrigation. The weak impact of extension services on irrigation implies limited advisory services on agricultural water management, which is a typical problem in SSA (Shah et al. 2002).

Table 4.8 Drivers of cooking energy source in Mozambique $(\mathrm{N}=10,798)$

\begin{tabular}{|c|c|c|c|c|c|c|c|c|}
\hline & \multicolumn{2}{|c|}{ Charcoal } & \multicolumn{2}{|c|}{ Fuelwood } & \multicolumn{2}{|c|}{ Paraffin } & \multicolumn{2}{|c|}{ Electricity } \\
\hline & Structural & Reduced & Structural & Reduced & Structural & Reduced & Structural & Reduced \\
\hline \multicolumn{9}{|l|}{ Human capital } \\
\hline $\begin{array}{l}\text { Grow tobacco } \\
\text { Have bank }\end{array}$ & $-2.942^{* \star *}$ & & $3.275^{\star \star *}$ & & $-2.910^{\star \star *}$ & & $-2.143^{\star \star \star}$ & \\
\hline account & $0.386^{* * *}$ & & $-0.569 * * *$ & & 0.061 & & 0.18 & \\
\hline \multicolumn{9}{|c|}{ Primary activity of household head (compare crop production) } \\
\hline $\begin{array}{l}\text { Ln(hours doing } \\
\text { nonfarm } \\
\text { activities) }\end{array}$ & $0.040^{* * *}$ & & -0.013 & & 0.01 & & -0.038 & \\
\hline Livestock & 0.138 & 0.195 & 0.145 & 0.021 & $-3.005^{\star * *}$ & $-3.024^{* * *}$ & $-3.068^{\star * \star}$ & $-2.895^{* * *}$ \\
\hline $\begin{array}{l}\text { Ln(household } \\
\text { size) }\end{array}$ & $-0.166^{\star * \star}$ & $-0.161^{* \star *}$ & $0.391^{* * *}$ & $0.387^{* * *}$ & -0.078 & -0.077 & $-0.266^{\star \star *}$ & $-0.274^{* * *}$ \\
\hline $\begin{array}{l}\text { Ln(age } \\
\text { household } \\
\text { head) }\end{array}$ & $-0.320^{* * *}$ & $-0.289^{* * *}$ & $0.157^{* * *}$ & $0.107^{* *}$ & $-0.269^{* *}$ & $-0.269^{* *}$ & -0.221 & -0.175 \\
\hline $\begin{array}{l}\text { Female- } \\
\text { headed } \\
\text { household }\end{array}$ & 0.063 & 0.044 & -0.047 & -0.029 & -0.056 & -0.059 & 0.119 & 0.117 \\
\hline \multicolumn{9}{|c|}{ Level of education of household head (compare no formal education) } \\
\hline $\begin{array}{l}\text { Primary } \\
\text { education } \\
\text { Secondary } \\
\text { education }\end{array}$ & $0.332^{* * *}$ & $0.358^{* * *}$ & $\begin{array}{l}-0.231^{* * *} \\
-0.544^{* * *}\end{array}$ & $\begin{array}{l}-0.262^{* * *} \\
-0.718^{* * *}\end{array}$ & $\begin{array}{l}-0.099 \\
-0.193\end{array}$ & $\begin{array}{l}-0.097 \\
-0.178\end{array}$ & $0.683^{* * *}$ & $0.748^{* * *}$ \\
\hline $\begin{array}{l}\text { Postsecondary } \\
\text { education }\end{array}$ & -0.099 & 0.07 & $-0.905^{\star * \star}$ & $-1.212^{\star * *}$ & $-3.058^{* * *}$ & $-3.029^{* * *}$ & $1.078^{* * *}$ & $1.172^{* * *}$ \\
\hline \multicolumn{9}{|c|}{ Income quintile (compare lowest quintile) } \\
\hline $\begin{array}{l}\text { Middle } \\
\text { expenditure } \\
\text { quintile }\end{array}$ & $0.545^{* * *}$ & $0.574^{* * *}$ & $-0.424^{\star * *}$ & $-0.454^{* * *}$ & -0.166 & -0.164 & 0.18 & 0.195 \\
\hline $\begin{array}{l}\text { Highest } \\
\text { expenditure } \\
\text { quintile }\end{array}$ & $0.682^{* * *}$ & $0.776^{\star * *}$ & $-0.751^{* * *}$ & $-0.859^{* * *}$ & 0.011 & 0.02 & $0.507^{* * *}$ & $0.554^{* * *}$ \\
\hline Own radio & 0.043 & 0.049 & $0.103^{* * *}$ & $0.093^{* *}$ & -0.051 & -0.05 & -0.024 & -0.027 \\
\hline Own television & $0.334^{* * *}$ & $0.439 * * *$ & $-0.664^{\star * \star}$ & $-0.814^{\star * *}$ & -0.195 & -0.175 & $0.273^{*}$ & $0.308^{* *}$ \\
\hline \multicolumn{9}{|c|}{ Access to rural services } \\
\hline $\begin{array}{l}\text { Ln(time to } \\
\text { market) }\end{array}$ & $-0.242^{* * *}$ & $-0.245^{\star * *}$ & $0.330^{* * *}$ & $0.337^{* * *}$ & $-0.094^{*}$ & $-0.094^{*}$ & $-0.101^{* *}$ & $-0.108^{* *}$ \\
\hline $\begin{array}{l}\text { Reside in } \\
\text { urban area }\end{array}$ & $1.584^{* * *}$ & $1.635^{\star * *}$ & $-1.240^{\star * *}$ & $-1.312^{* \star *}$ & -0.148 & -0.136 & $0.341^{* *}$ & $0.367^{* *}$ \\
\hline Constant & $-0.908^{* * *}$ & $-1.033^{* * *}$ & $0.377^{*}$ & $0.586^{* * *}$ & $-0.946^{*}$ & $-0.947^{*}$ & $-2.264^{\star * *}$ & $-2.436^{* * *}$ \\
\hline
\end{tabular}

Source: Authors' calculations.

Note: $\quad *, * *$, and $* * *$ indicates $10 \%, 5 \%$ and $1 \%$ significance level, respectively. 
Table 4.9 Drivers of irrigation, Mozambique $(N=5,783)$

\begin{tabular}{lcc}
\hline Variable & Structural form probit & Reduced form probit \\
\hline Female-headed household & 0.034 & 0.008 \\
Household size & $0.022^{* *}$ & $0.021^{* * *}$ \\
Education primary (compare no education) & 0.086 & $0.178^{* * *}$ \\
Education secondary & $0.217^{* * *}$ & $0.286^{* * *}$ \\
Education postsecondary & $1.165^{* *}$ & $1.216^{* *}$ \\
Land medium (compare land poor) & $0.310^{* * *}$ & $0.319^{* * *}$ \\
Land rich & $0.389^{* * *}$ & $0.461^{* * *}$ \\
Own livestock & 0.072 & $0.237^{* * *}$ \\
Have cashew nut trees on farm & 0.004 & -0.042 \\
Have fruit trees on farm & $0.216^{* * *}$ & $0.414^{* * *}$ \\
Extension training & 0.053 & - \\
Use fertilizers & $1.062^{* * *}$ & - \\
Use pesticide & $0.492^{* * *}$ & - \\
Use manure & $2.191^{* * *}$ & - \\
Constant & $-2.258^{* * *}$ & $-2.135^{* * *}$ \\
\hline
\end{tabular}

Source: National Agricultural Survey 2008 (MINAG 2009)

Note: $*, * *$ and $* * *$ indicates $10 \%, 5 \%$ and $1 \%$ significance level, respectively.

In the above analyses of the use of and the drivers of the adoption of FEW technologies, we observe large differences between Malawi and Mozambique. While other factors could explain these between two neighboring countries, a strong influence of national-level policies on farmer behavior is likely. This is supported by the findings that farmers in Malawi are more likely to use fertilizer and less likely to use irrigation compared with farmers in Mozambique. To support this hypothesis, an investigation on the impacts of national-level policies on farmer behavior using more rigorous data is needed. The findings, however, also highlight that despite strong public and private investment in ICSs, woodfuel remains the major source of energy in Malawi. This may stem from lagged impacts of the ICS and other weaknesses in the commercialization of ICS programs. These hypotheses too deserve a more rigorous analysis. Common characteristics across the two countries could result from similar policy features. For example, the use of organic inputs is low in both countries, reflecting the limited capacity of extension service providers to provide integrated soil fertility management (ISFM) practices. Another future research topic with policy relevance is to examine the perception of farmers on a hypothetical conditional fertilizer subsidy, which could help promote the adoption of ISFM. The drivers of adoption also provide guidance on the way to conduct our study. 


\section{CONCLUSIONS}

The FEW nexus can allow stakeholders to discuss, draft, adopt, and analyze policies that impact food, energy, and water security at the micro- and macrolevels. Thus far, a clear definition of the FEW nexus has been missing from the discussion. We proposed that the FEW nexus be defined as encompassing synergies and trade-offs between food, energy, and water security that are impacted by endogenous and exogenous drivers and cannot be captured if these sectors are analyzed in isolation. Moreover, we specified that a nexus intervention must impact all three components of the nexus and at least one impact must be direct. Although policies that have been created and analyzed as FEW nexus interventions are rare, many examples of interventions aiming at improving food, energy, or water security can be deemed FEW nexus interventions given their direct and indirect impacts on food, energy, or water security. For example, the review of nexus interventions in Section 2 showed that both Malawi and Mozambique have implemented several nexus interventions during the past few decades. Although none have been analyzed within the nexus framework thus far, the existing evidence illustrates the trade-offs and synergies in terms of food, water, and energy security at the macro- and microlevels that these interventions have already entailed. Since these effects were often not taken into account when the policies were introduced, evidence on the effects of FISP, hydroenergy, the Green Belt Initiative, biofuels, and agroforestry projects in Malawi and Mozambique emphasize the need to examine both countries' policies from a nexus perspective. This would allow the identification of interventions that minimize trade-offs and maximize synergies among food, water, and energy security.

Both macro- and microlevel analyses are critical for analyzing and simulating actual and potential impacts of nexus interventions and their effect on different segments of society. Methods to analyze FEW nexus interventions from a macro and micro perspective were described in Sections 3 and 4 , respectively. While some existing partial equilibrium models can be used to analyze parts of the nexus in detail, general equilibrium models are able to take all linkages and resource constraints within an economy into account by capturing the complete circular flow of income. Through the combination of microeconomic behavioral assumptions as well as macroeconomic closures, CGE models are able to simulate policy effects on both the macro- and microlevels of economic activity and evaluate respective trade-offs and synergies. Although the measurement of food, water, and energy security at the macro- and microlevels in developing countries entails difficulties due to informal or nonexisting markets, the combination of CGE with ecological models is able to remedy these problems and is an appropriate framework to analyze the complex effects of nexus interventions on the nexus itself as well as the whole economy. While it is important to keep in mind that simulation models cannot make predictions about actual events, they can improve policymaking by increasing the understanding of potential policy effects. The end of Section 3 contained an application of a macrolevel analysis of a nexus intervention, namely, small-scale irrigation. As for a microlevel analysis, quantitative and qualitative methods can be applied to assess nexus interventions. Caution should be taken to avoid aggregation issues, and targeting should be carefully planned. Results should be examined with a gender perspective, and outcome variables must be carefully selected. Similar to a macrolevel analysis, challenges arise in evaluating nexus intervention effects and trade-offs at the household level. The end of Section 4 contained a microlevel FEW nexus analysis of secondary data from Malawi and Mozambique. Given the data constraints faced in these analyses conducted thus far, we emphasize the need for better quality and more comprehensive data on food, energy, and water securities, so that a more thorough analysis of FEW nexus interventions can be conducted.

As researchers and policymakers change their perspectives to see the interconnectedness of development issues, the nexus approach will become more common. Ideally, such a paradigm shift will lead to regional collaboration on nexus interventions to better manage natural resources and improve livelihoods. Stakeholders need to be aware of and face collective action problems and constraints to multidisciplinary collaboration head on, however, for the nexus approach to succeed. 


\section{REFERENCES}

AfDB (African Development Bank). 2011. Republic of Mozambique: Country Strategy Paper 2011-2015. Abidjan: African Development Bank.

AGRA (Alliance for a Green Revolution in Africa). 2014. Africa Agriculture Status Report 2014: Climate Change and Smallholder Agriculture in sub-Saharan Africa. Nairobi, Kenya.

Ajayi, O. C., F. Place, F. K. Akinnifesi, and G. Sileshi. 2011. “Agricultural Success from Africa: The Case of Fertilizer Tree Systems in Southern Africa (Malawi, Tanzania, Mozambique, Zambia, and Zimbabwe).” International Journal of Agricultural Sustainability 9 (1): 129-136.

Ajayi, O. C., F. Place, F. Kwesiga, and P. Mafongoya. 2006. Impact of Natural Resource Management Technologies: Fertilizer Tree Fallows in Zambia. Occasional Paper No. 5. Nairobi, Kenya: World Agroforestry Centre.

Akinnifesi F., O. C. Ajayi, G. Sileshi, P. W. Chirwa, and J. Chianu. 2010. Fertiliser Trees for Sustainable Food security in the maize-based production systems of East and Southern Africa. A Review. Agronomy for Sustainable Development 30: 615-629.

Akinnifesi, F. K., P. W. Chirwa, O. C. Ajayi, G. Sileshi, P. Matakala, F. R. Kwesiga, H. Harawa, and W. Makumba. 2008. "Contributions of Agroforestry Research to Livelihood of Smallholder Farmers in Southern Africa: 1. Taking Stock of the Adaptation, Adoption and Impact of Fertilizer Tree Options." Agricultural Journal 3: 58-75

Akinnifesi, F. K., W. Makumba, G. Sileshi, O. C. Ajayi, and D. Mweta. 2007. "Synergistic Effect of Inorganic $\mathrm{N}$ and $\mathrm{P}$ Fertilizers and Organic Inputs from Gliricidia sepium on Productivity of Intercropped Maize in Southern Malawi." Plant Soil 294: 203-217

Anand, S., and M. Ravallion. 1993. "Human Development in Poor Countries: On the Role of Private Incomes and Public Services." Journal of Economic Perspective 7 (1): 133-150.

Arndt, C., R. Benfica, F. Tarp, N. Maximiano, A. M. D. Nucifora, and J. Thurlow. 2008. Higher Fuel and Food Prices, Economic, Impacts and Responses for Mozambique. Discussion Paper 00836. Washington, DC: International Food Policy Research Institute.

Arndt, C., R. Benfica, F. Tarp, J. Thurlow, and R. Uaiene. 2010. "Biofuels, Poverty, and Growth: A Computable General Equilibrium Analysis of Mozambique.” Environment and Development Economics 15 (1): 81105.

Arndt, C., S. Msangi, and J. Thurlow. 2010. Are Biofuels Good for African Development? An Analytical Framework with Evidence from Mozambique and Tanzania. UNU-WIDER Working Paper No. 2010 / 110. Helsinki, Finland: UNU-WIDER.

Arndt, C., K. Pauw, and J. Thurlow. 2013. The Economywide Impacts and Risks of Malawi's Farm Input Subsidy Program. Invited paper presented at the 4th International Conference of the African Association of Agricultural Economists, September 22-25, Hammamet, Tunisia.

Asayehegn, K. 2012. "Negative Impact of Small-Scale Irrigation Schemes: A Case Study of Central Tigray Regional State, Ethiopia. Agricultural Research and Reviews 1 (3): 80-85.

Bailis, R., Ezzatti, M., and Kammen, D. 2007. "Health and Greenhouse Gas Impacts of Biomass and Fossil Fuel Energy Futures in Africa." Boiling Point 54: 3-8.

Bandyopadhyay, S., P. Shyamsundar, and A. Baccini. 2011. "Forests, Biomass Use and Poverty in Malawi." Ecological Economics 70: 2461-2471.

Barnes, R. D., and C. W. Fagg. 2003. Faidherbia albida. Monograph and Annotated Bibliography. Tropical Forestry Papers No. 41, Oxford Forestry Institute, Oxford, UK.

Barrett, C. 2008. "Smallholder Market Participation: Concepts and Evidence from Eastern and Southern Africa." Food Policy 33 (4): 299-317.

Bates, R. H. 1981. Markets and States in Tropical Africa: The Political Basis of Agricultural Policies. Berkley: University of California Press. In "Analyzing Nutritional Impacts of Policies: An Empirical Study for Malawi,” by O. Ecker and M. Qaim. 2011. World Development 39 (3): 412-428. 
Bazilian, M., H. Rogner, M. Howells, S. Hermann, D. Arent, D. Gielen, P. Steduto, A. Mueller, P. Komor, R. S. J. Tol, and K. K. Yumkella. 2011. "Considering the Energy, Water and Food Nexus: Towards an Integrated Modelling Approach.” Energy Policy 39 (12): 7896-7906.

Beedy, T. L., O. C. Ajayi, G. W. Sileshi, G. Kundhlande, G. Chiundu, and A. J. Simons. 2012. “Scaling Up Agroforestry to Achieve Food Security and Environmental Protection among Smallholder Farmers in Malawi." Field Actions Science Reports Special Issue 7: Livelihoods.

Bensch, G., Peters, J., and L. Schraml. 2010. Energy Usage and Socioeconomic Conditions in Mozambique: Evidence from GTZ Electrification Project Regions. RWI Materialien No. 56. http://hdl.handle.net/10419/61115.

Benson, T., S. Woldeyohannes, and T. Mogues. 2013. Mozambique Agriculture Joint Sector Review 2013: Assessing Progress Made towards Shared Agricultural Transformation Objectives in Mozambique. Washington, DC: International Food Policy Research Institute.

BERL (Bio Energy Resource Ltd.). 2014. Bio Energy Resources Ltd. Accessed January 31, 2014. www.berl.biz/.

Biggs, T. 2012. Mozambique's Coming Natural Resource Boom: Expectations, Vulnerabilities, and Policies for Successful Management. Maputo, Mozambique: USAID/Mozambique.

Böhringer, C., T. F. Rutherford, and W. Wiegard. 2003 Computable General Equlibrium Analysis: Opening a Black Box. ZEW Discussion Paper No. 03-56. Bonn, Germany: ZEW.

Booth, T. 1988. Developing Policy Researcher. Gower: Aldershot.

Borras Jr., S. M., D. Fig, and S. M. Suárez. 2011. "The Politics of Agrofuels and Mega-land and Water Deals: Insights from the ProCana Case, Mozambique." Review of African Political Economy 38 (128): 215234.

Boserup, E. 1965. The Conditions of Agricultural Growth: The Economics of Agrarian Change under Population Pressure. New York: Aldine Press.

Bourguignon, F., and A. Spadaro. 2006. "Microsimulation as a Tool for Evaluating Redistribution Policies." Journal of Economic Inequality 4: 77-106.

Boyd, C., and T. Slaymaker. 2000. "Re-examining the 'More People Less Erosion' Hypothesis: Special Case or Wider Trend?” Natural Resource Perspectives 63 (November): 1-6.

Breisinger, C., M. Thomas, and J. Thurlow. 2009. Social Accounting Matrices and Multiplier Analysis: An Introduction with Exercises. Food Security in Practice Technical Guide 5. Washington, DC: International Policy Research Institute.

Brunner, C. 1991. Thinking Collaboratively: Ten Questions and Answers to Help Policy Makers Improve Children's Services. Washington, DC: Education and Human Service Consortium, Institute for Educational Leadership.

Burney, J., J. Woltering, M. Burke, R. Naylor, and D. Pasternak. 2010. "Solar-Powered Drip Irrigation Enhances Food Security in Sudano-Sahel." Proceedings of the National Academy of Sciences 107 (5): $1848-1853$.

Campbell, L. 2005. “Overcoming Obstacles to Interdisciplinary Research.” Conservation Biology 19 (2): 574 577.

Carney, D. 1998. "Implementing the Sustainable Rural Livelihoods Approach.” In Sustainable Rural Livelihoods: What Contribution Can We Make?, edited by D. Carney, 2-23. London: U.K. Department for International Development.

Challis, L., S. Fuller, M. Henwood, R. Klein, W. Plowden, A. Webb, P. Whittingham, and G. Wistow. 1988. Joint Approaches to Social Policy: Rationality and Practice. Cambridge: Cambridge University Press.

Chambal, H. 2010. Energy Security in Mozambique. International Institute for Sustainable Development, Series on Trade and Energy Security. Policy Report 3. Winnipeg, Canada: IISD.

Chianu, J. N., Adesina, A., Sanginga, P., Bationo, A., Chianu, J., and N. Sanginga. 2008. "Structural Change in Fertilizer Procurement Method: Assessment of Impact in Sub-Saharan Africa." African Journal of Business Management 2 (3): 65-71. 
Chibwana, C., M. Fisher, and G. Shively. 2012. "Cropland Allocation Effects of Agricultural Input Subsidies in Malawi." World Development 40 (1): 124-133.

Chibwana, C., C. Jumbe, and G. Shively. 2012. "Agricultural Subsidies and Forest Clearing in Malawi." Environmental Conservation 40 (1): 60-70.

Chibwana, C., G. Shively, M. Fisher, C. Jumbe, and W. Masters. 2014. "Measuring the Impacts of Malawi's Farm Input Subsidy Program." African Journal of Agricultural and Resource Economics 9 (2): 132147.

Chinsinga, B., and M. Chasukwa. 2012. The Green Belt Initiative and Land Grabs in Malawi. Future Agricultures Consortium, Policy Brief 55. Brighton, UK: The Future Agricultures Consortium.

Chirwa, T. G. 2010. Program Evaluation of Agricultural Input Subsidies in Malawi Using Treatment Effects: Methods and Practicability Based on Propensity Scores. Munich Personal RePEc Archive (MPRA). Accessed March 2013. http://mpra.ub.uni-muenchen.de/21236/.

Chirwa, E. W., P. M. Mvula, A. Dorward, and M. Matita. 2011. Gender and Intra-Household Use of Fertilizers in the Malawi Farm Input Subsidy Program. Future Agriculture Working Paper 02. Accessed March 2013. www.dfid.gov.uk/r4d/PDF/Outputs/Futureagriculture/FAC_Working_Paper_028.pdf.

Concern Universal. 2012. Socio-Cultural Acceptability of Improved cookstoves in Balaka, Dedza and Mulanje, 2012. Final Full Report. Lilongwe, Malawi: Concern Universal and Irish Aid.

2013. "President Banda Attends National Cookstoves Launch, Malawi.” January 9, 2013.

www.concern-universal.org/president_banda_attends_national_cookstoves_lau.

Cooke P., G. Köhlin, and W. F. Hyde. 2008. "Fuelwood, Forests and Community Management: Evidence from Household Studies." Environment and Development Economics 13: 103-135

Creedy, J., and G. Kalb. 2005. Behavioural Microsimulation Modelling with the Melbourne Institute Tax and Transfer Simulator (MITTS): Uses and Extensions. Research Paper No. 932. Melbourne, Australia: University of Melbourne.

Davidson, R., and J. G. MacKinnon. 2004. Econometric Theory and Methods. Oxford, UK: Oxford University Press.

Dawson, I., P. Place, E. Torquebiau, E. Malézieux, M. Iiyama, G. Sileshi, K. Kehlenbeck, E. Masters, S. McMullin, and R. Jamnadass. 2013. “Agroforestry, Food and Nutritional Security.” Background paper for the International Conference on Forests for Food Security and Nutrition, Food and Agriculture Organization (FAO), Rome. May 13-15.

De Fraiture, C., M. Giordano, and Y. Liao. 2008. "Biofuels and Implications for Agricultural Water Use: Blue Impacts OF Green Energy. Water Policy 10 (S1): 67-81.

De Soto, H. 2000. The Mystery of Capital: Why Capitalism Triumphs in the West and Fails Everywhere Else. New York: Basic Books.

Dervis, K., J. De Melo, and S. Robinson. 1982. General Equilibrium Models for Development Policy. New York: Cambridge University Press.

Diao, X., Hazell, P., Resnick, D., Thurlow, J. 2007. The Role of Agriculture in Pro-poor Growth in SubSaharan Africa. Research Report 144. Washington, DC: International Food Policy Research Institute.

Diao, X., and J. Thurlow. 2012. “A Recursive Dynamic Computable General Equilibrium Model.” In Strategies and Priorities for African Agriculture: Economywide Perspectives from Country Studies, edited by X. Diao, J. Thurlow, S. Benin, and S. Fan. Washington, DC: International Food Policy Research Institute.

Direcção Nacional de Águas. 1999. Water Resources of Mozambique. SYNOPSIS 1999. Ministry of Public Works and Housing. Maputo, Mozambique: Cooperation Portugal-Mozambique.

Dorward, A., E. Chirwa, V. A. Kelly, T. S. Jayne, R. Slater, and D. Boughton. 2008. Evaluation of the 2006/2007 Agricultural Input Subsidy Programme, Malawi. Final Report submitted to the Ministry of Agriculture and Food Security. Lilongwe, Malawi. http://ageconsearch.umn.edu/bitstream/97143/2/AISPFinalReport31March.pdf. Accessed September $11,2013$. 
Dorward, A., J. Morrison, P. Wobst, H. Lofgren, and H. Tchale. 2004. "Modelling Pro-Poor Agricultural Growth Strategies in Malawi: Lessons for Policy and Analysis. African Development and Poverty Reduction: The Macro-Micro Linkage.” Forum Paper, Somerset West, South Africa. October 13-15.

Doss, C. R. 1999. "Twenty-Five Years of Research on Women Farmers in Africa: Lessons and Implications for Agricultural Research Institutions; with an Annotated Bibliography." CIMMYT Economics Program Paper 00-02. Mexico, D.F.: Centro Internacional de Mejoramiento de Maíz y Trigo (CIMMYT).

Doss, C. R., and M. L. Morris. 2001. "How Does Gender Affect the Adoption of Agricultural Innovations? The Case of Improved Maize Technology in Ghana.” Agricultural Economics 25 (1): 27-39.

Dosskey, M. G. 2002. "Setting Priorities for Research on Pollution Reduction Functions of Agricultural Buffers.” Environmental Management 30: 641-650.

Douillet, M., K. Pauw, and J. Thurlow. 2012. "Macro Evaluation of Program Impacts and Risks: The Case of Malawi’s Farm Input Subsidy Program (FISP).” Accessed April 14, 2014.

https://editorialexpress.com/cgi-bin/conference/download.cgi?db name=CSAE2013andpaper id=863.

Ecker, O., C. Breisinger, and K. Pauw. 2011. “Growth Is Good but Is Not Enough to Improve Nutrition.” 2020 Conference: Leveraging Agriculture for Improving Nutrition and Health, 2020 Conference Paper 7, New Delhi, India. February 10-12.

Ecker, O., and M. Qaim. 2011. "Analyzing Nutritional Impacts of Policies: An Empirical Study for Malawi." World Development 39 (3): 412-428.

Ellison D., M. Futter, and K. Bishop. 2012. "On the Forest Cover-Water Yield Debate: From Demand- to Supply-Side Thinking.” Global Change Biology 18: 806-820.

ESCOM (Electricity Supply Corporation of Malawi). 2013. "Generation Directorate.” Accessed October 10, 2013. www.escom.mw/generation.php.

Ewing, M., and S. Msangi. 2009. "Biofuels Production in Developing Countries: Assessing Trade-offs in Welfare and Food Security.” Environmental Science and Policy 12 (4): 520-528.

FAO (Food and Agriculture Organization of the United Nations). 2005. Global Forest Resources Assessment 2005 - Progress towards sustainable forest management. FAO Forestry Paper 147. Rome.

- 2006. Fertilizer Use by Crop. Fertilizer and Plant Nutrition Bulletin 17. Rome.

—. 2010. What Woodfuels Can Do to Mitigate Climate Change? FAO Forestry Paper 162, Rome.

2011. 2011 Global Forest Products Facts and Figures, Rome.

- 2014. FAOSTAT database. Accessed September 2014. http://faostat.fao.org/.

2015. FAOSTAT database. Accessed October 19, 2014. http://faostat3.fao.org/home/E.

FAO and CIMMYT (International Maize and Wheat Improvement Center). 1997. White Maize: A Traditional Food Grain in Developing Countries: A Joint Study." Rome: FAO.

FAO, IFAD (International Fund for Agricultural Development), and WFP (World Food Programme). 2013. The State of Food Insecurity in the World 2013. The Multiple Dimensions OF Food Security. Rome: FAO.

FAO, WHO (World Health Organization), and UNU (United Nations University) Committee. 1985. Energy and Protein Requirements. WHO Technical Report Series 724. Geneva.

—. 2001. Human Energy Requirements. FAO Food and Nutrition Technical Report Series 1. Rome.

Feder, G. 1985. "The Relation between Farm Size and Farm Productivity.” Journal of Development Economics 18: $297-313$.

Fekete B.M., C.J. Vörösmarty, and W. Grabs. 2002. "High-resolution fields of global runoff combining observed river discharge and simulated water balances." Global Biogeochem. Cyles 16(3): Art. No. 1042 .

Felderer, B., and S. Homburg. 2005. Makroökonomik und neue Makrö̈konomik. Berlin, Heidelberg: Springer.

Fisher, M. 2004. "Household Welfare and Forest Dependence in Southern Malawi." Environment and Development Economics 9: 135-154.

Fisher, M., and V. Kandiwa. 2014. Can Agricultural Input Subsidies Reduce the Gender Gap in Modern Maize Adoption? Evidence from Malawi. Food Policy 45: 101-111. 
Gao, Y., M. Skutsch, O. Masera, and P. Pacheco. 2011. A Global Analysis of Deforestation Due to Biofuel Development. Working Paper 68. Bogor, Indonesia: Center for International Forestry Research (IFOR).

Garrity, D., F. Akinnifesi, O. Ajayi, S. Weldesemayat, J. Mowo, A. Kalinganire, M. Larwanou, and J. Bayala. 2010. "Evergreen Agriculture: A Robust Approach to Sustainable Food Security in Africa." Food Security 2 (3): 197-214.

Gemo, H. R. 2011. "Moving towards the Implementation of the CAADP Framework in the Agriculture Sector: The Case of Mozambique." Background paper for the CAADP-Mozambique Process, Midrand, South Africa: New Partnership for Africa's Development (NEPAD).

Gerholdt, J., and D. Pandya. 2009. "The Energy, Water, Food Nexus.” Resources 2, Conservation International.

Gifford, M. 2010. “A Global Review of Cookstove Programs.” Master's dissertation, Berkeley University. www.eecs.berkeley.edu/ sburden/misc/mlgifford_ms thesis.pdf. Accessed December 31, 2014.

GOM (Government of Malawi). 1998. Vision 2020. National Long-Term Perspective for Malawi. Accessed September 24, 2015. www.sdnp.org.mw/.

GOMOZ (Government of Mozambique). 2001. Action Plan for the Reduction of Absolute Poverty, 2001-2005 (PARPA). Maputo, Mozambique.

2006. Action Plan for the Reduction of Absolute Poverty 2006-2009 (PARPA II). Maputo, Mozambique.

. 2011. Poverty Reduction Action Plan (PARP) 2011-2014. Maputo, Mozambique.

Habermehl, H. 2008. Costs and Benefits of Efficient Institutional Cookstoves in Malawi: Economic Evaluation of the Component "Promotion of Efficient Institutional Cookstoves" of the Programme for Biomass Energy Conservation (ProBEC) in Malawi in the Years 2004 to 2007. Household Energy Programme. Eschbor, Germany: Deutsche Gesellschaft für Technische Zusammenarbeit (GTZ).

Hanlon, P., R. Madel, K. Olson-Saxyer, K. Rabin, and J. Rose. 2013. Food, Water and Energy: Know the Nexus. January. New York: GRACE Communications Foundation.

Hardin, G. 1968. “The Tragedy of the Commons.” Science New Series 162 (3859): 1243-1248.

Hardy, B., A. Turrell, and G. Wistow. 1992. Innovations in Community Care Management. Avebury, UK: Aldershot.

Hassan, R., and J. Thurlow. 2011. "Macro-Micro Feedback Links of Water Management in South Africa: CGE Analyses of Selected Policy Regimes." Agricultural Economics 42 (2): 235-247.

Hecky, R. E., H. A. Bootsma, and M. L. Kingdon. 2003. "Impact of Land Use on Sediment and Nutrient Yields to Lake Malawi/Nyasa (Africa).” J. Great Lakes Res. 29: 139-158.

Hellegers, P., D. Zilberman, P. Steduto, and P. McCornick. 2008. "Interactions between Water, Energy, Food and Environment: Evolving Perspectives and Policy Issues." Water Policy 10 (S1): 1.

Heltberg, R., and F. Tarp. 2002. “Agricultural Supply Response and Poverty in Mozambique.” Food Policy 27: $103-124$

Herrmann, R., U. Grote, and M. Brüntrup. 2013. "Household Welfare Outcomes of Large-Scale Agricultural Investments: Insights from Sugarcane Outgrower Schemes and Estate Employment in Malawi.” Paper prepared for presentation at the Annual World Bank Conference on Land and Poverty, Washington, DC, World Bank. April 8-11.

HLPE (High Level Panel of Experts). 2013. Biofuels and Food Security. A report by the High Level Panel of Experts on Food Security and Nutrition of the Committee on World Food Security. Rome.

Hoddinott, J. 2011. “Agriculture, Health, and Nutrition: Toward Conceptualizing the Linkages.” Paper presented at 2020 Conference: Leveraging Agriculture for Improving Nutrition and Health, New Delhi, India. February 10-12.

Hoff, H. 2011. "Understanding the Nexus.” Background Paper for the Bonn 2011 Conference: The Water, Energy and Food Security Nexus. Stockholm, Sweden: Stockholm Environment Institute.

Holden, S. T., and R. Lunduka. 2010. Too Poor to Be Efficient? Impacts of the Targeted Fertilizer Subsidy Program in Malawi on Farm Plot Level Input Use, Crop Choice and Land Productivity. Noragric 
Report No. 55. Department of Economics and Resource Management. Aas, Norway: Norwegian University of Life Sciences.

2012a. "Who Benefit from Malawi's Targeted Farm Input Subsidy Program?" Journal of Development Studies 39 (3): 290-314. http://dx.doi.org/10.1080/08039410.2012.688858.

2012b. "Do Fertilizer Subsidies Crowd Out Organic Manures? The Case of Malawi." Agricultural Economics 43 (3): 303-314.

Horst, G. H., and A. J. Hovorka. 2009. “Fuelwood: The 'Other' Renewable Energy Source for Africa?” Biomass and Bioenergy 33: 1605-1616.

Houssou, N., and M. Zeller. 2011. "To Target or Not to Target? The Costs, Benefits, and Impacts of IndicatorBased Targeting." Food Policy 36 (5): 627-637.

Hudson, B., B. Hardy, M. Henwood, and G. Widtow. 1999. "In Pursuit of Inter-agency Collaboration in the Public Sector." Public Management 1 (2): 235-260.

Huxham, C., and D. MacDonald. 1992. "Introducing Collaborative Advantage." Management Decision 30 (3): 50-56.

ICF International. 2012. Natural Gas Master Plan for Mozambique-Draft Report, Executive Summary. Fairfax, VA, US: ICF International.

ICRISAT (International Crop Research Institute for the Semi-Arid Tropics). 2011. A Review of the Agricultural Input and Output Markets Development in Mozambique. Maputo, Mozambique.

IEA (International Energy Agency). 2006. World Energy Outlook. Accessed November 10, 2015. www.worldenergyoutlook.org/media/weowebsite/2008-1994/WEO2006.pdf.

_. 2013a. Tracking Clean Energy Progress 2013. IEA Input to the Clean Energy Ministerial. Paris. 2013b. World Energy Outlook 2013. Paris.

IEA (International Energy Agency), and ETSAP (Energy Technology Systems Analysis Program). 2014. Accessed January 10, 2014. www.iea-etsap.org/web/Markal.asp.

IFAD (International Fund for Agricultural Development), and UNEP (United Nationals Environment Programme). 2013. Smallholders, Food Security, and the Environment. Rome: IFAD. www.unep.org/pdf/SmallholderReport_WEB.pdf.

IGEL (Initiative for Global Environmental Leadership). 2013. The Nexus of Food, Energy and Water. Special Report. Philadelphia, PA, US: Wharton School of the University of Pennsylvania.

IIASA (International Institute for Applied Systems Analysis). 2013. “Message.” Accessed September 27, 2015. www.iiasa.ac.at/web/home/research/modelsData/MESSAGE/MESSAGE.en.html.

INE (Instituto Nacional de Estatística). 2009. Final Report of the Multiple Indicator Cluster Survey, 2008. Maputo, Mozambique.

_. 2010. Inquerito Sobre Orcameto Familiar - IOF 2008/2009. Maputo, Mozambique.

IWMI (International Water Management Institute), n.d. Managing Water for Rainfed Agriculture. Water Issue Brief, Issue 10. www.iwmi.cgiar.org/Publications/Water Issue Briefs/PDF/Water Issue Brief 10.pdf.

Isaacman, A., and C. Sneddon. 2000. "Toward a Social and Environmental History of the Cahora Bassa Dam." Journal of Southern African Studies 26 (4): 597-632.

Kaluwa, P. W. R., F. M. Mtambo, and R. Fachi. 1997. "The Country Situation Report on Water Resources in Malawi. Lilongwe UNDP/SADC Water Initiative." In "The Use and Management of Water in the Likangala Irrigation Scheme Complex in Southern Malawi,” by W. O. Mulwafu, and B. G. Nkhoma, Physics and Chemistry of the Earth (2002) 27: 839-844.

Kambewa, P., and L. Chiwaula. 2010. “Biomass Energy Use in Malawi.” A background paper prepared for the International Institute for Environment and Development (IIED) for an International ESPA Workshop on Biomass Energy, Parliament House Hotel, Edinburgh. Chancellor College, Zomba, Malawi. October 19-21.

Kambewa, P. S., B. F. Mataya, W. K. Sichinga, and T. R. Johnson. 2007. Charcoal-The Reality: A Study of Charcoal Consumption, Trade and Production in Malawi. Technical Report to the Forest Governance Learning Group. Blantyre, Malawi: Malawi COMPASS II. 
Kondylis, F., and V. Mueller. 2012. Seeing Is Believing? Evidence from a Demonstration Plot Experiment in Mozambique. Mozambique Strategy Support Program, Working Paper 1. Washington, DC: International Food Policy Research Institute.

Kwesiga F., F. K. Akinnifesi, P. L. Mafongoya, M. H. Mcdermott, and A. Agumya. 2003. “Agroforestry Research and Development in Southern Africa during 1990s: Review and Challenges Ahead." Agroforestry Systems 53: 173-186.

Lal, R. 2013. The Nexus of Soil, Water and Waste. Lecture Series No. 1. Dresden: United Nations University Institute for Integrated Management of Material Fluxes and of Resources.

Lamb, R. L. 2003. “Inverse Productivity: Land Quality, Labor Markets, and Measurement Error.” Journal of Development Economics 71 (1): 71-95.

Lehner, B., and P. Döll. 2004. "Development and Validation of a Global Database of Lakes, Reservoirs and Wetlands.” Journal of Hydrology 296 (1-4): 1-22.

Lin, N. 2001. Social Capital: A Theory of Structure and Action. London and New York: Cambridge University Press.

Linyunga, K., P. Matakala, and R. Chintu. 2004. “Accelerating Agroforestry Adoption: A Case of Mozambique.” Paper presented at the IUFRO Congress, Rome. July 12-15.

Lipton, M. 1977. Why Poor People Stay Poor: A Study of Urban Bias in World Development.” London: Temple Smith.

Locke, A., and G. Henley. 2014. Biofuels and Local Food Security. What Does the Evidence Say? ODI Briefing 86. London: Overseas Development Institute.

Lunduka, R., J. Ricker-Gilbert, and M. Fisher. 2013. "What Are the Farm-Level Impacts of Malawi’s Farm Input Support Program? A Critical Review.” Agricultural Economics 44 (6): 563-579.

Mahumane, G., P. Mulder, and N. David. 2012. Energy Outlook for Mozambique 2012-2030 LEAP-based Scenarios for Energy Demand and Power Generation. Maputo, Mozambique: Instituto de Estudos Sociais e Economicos.

Manibog, F. R. 1984. "Improved Cooking Stoves in Developing Countries: Problems and Opportunities." Annual Review of Energy 91 (11): 199-227.

Mason, N., and J. Ricker-Gilbert. 2013. "Disrupting Demand for Commercial Seed: Input Subsidies in Malawi and Zambia." World Dev. 45: 75-91.

Maupin, A. 2013. "Regional Approach for Water Policies in Southern Africa." Lesedi-IFAS Research Newsletter 15: 10-16. hal-00786053.

McCalla, A. 1997. "Water, Food and Trade.” Paper presented at the Mediterranean Development Forum convened by the World Bank, Marrakech, Morocco. March.

McCornick, P. G., S. B. Awulachew, and M. Abebe. 2008. "Water-Food-Energy-Environment Synergies and Trade-Offs: Major Issues and Case Studies.” Water Policy 10 (Suppl. 1): 23-36.

Mead, D. J. 2005. "Forests for Energy and the Role of Planted Trees.” Crit. Rev. Plant Sci. 24: 407-421.

Meade, B., and S. Rosen. 2013. International Food Security Assessment, 2013-2023. GFA 24. Economic Research Service. Washington, DC: U.S. Department of Agriculture.

2013. Plano Nacional de Investimentodo Sector Agrário (PNISA) 2013-2017. Maputo, Mozambique.

Malawi, MoAI (Ministry of Agriculture and Irrigation). 1999. Handing Over of Irrigation Schemes to Farmers: Recommendation for the Handover Process, TCP/MLW/6611 Project. Lilongwe, Malawi.

2000. Guidelines for the Hand over of Government Managed Irrigation Schemes to Smallholder Farmers. Lilongwe, Malawi.

Malawi, MoAIWD (Ministry of Agriculture, Irrigation and Water Development). 2015. National Irrigation Master Plan and Investment Framework. Lilongwe, Malawi.

Malawi, MoE (Ministry of Energy). 2009. Energy Development and Access Project: Resettlement Policy Framework. Lilongwe, Malawi. 
Molle, F., P. Jayakody, R. Ariyaratne, and H. S. Somatilake. 2008. "Irrigation versus Hydropower: Sectoral Conflicts in Southern Sri Lanka." Water Policy 10 (S1): 37.

Mozambique, MINAG (Ministério da Agricultura). 2009. National Agricultural Survey 2008 - Small- and Medium-sized Farm Holdings. Maputo, Mozambique.

Mozambique, MINAG (Ministério da Agricultura). 2010. Plano Estratégico Para o Desenvolvimentodo Secto Agrário (PEDSA) 2010-2019. Maputo, Mozambique.

Mucavele, F. 2009. "The True Contribution of Agriculture to the Economic Development of Mozambique." Paper presented at the Regional Stakeholders Policy Dialogue, Maputo, Mozambique. August 31September 4.

Mukherjee, C., H. White, and M. Wuyts. 1998. Econometric and Data Analysis for Developing Countries. London: Routledge.

Muller, M. 2013. "Let's Look Long Term: What Difference Will Nexus Thinking Have Made in 2050?" Presentation at Policy Forum Berlin 2013, Realising the Water, Energy and Food Security Nexus. Berlin, Germany. November 28-29.

Mulwafu, W. O., and B. G. Nkhoma. 2002. "The Use and Management of Water in the Likangala Irrigation Scheme Complex in Southern Malawi." Physics and Chemistry of the Earth 27: 839-844.

Murk, P. 1994. “Addressing Community Interagency Cooperation.” Economic Development Review 12 (3): 61-63.

Murugan, R. 2012. "Theory on the Dynamics of Feed Forward Loops in the Transcription Factor Networks." PLOS ONE 7 (7): 1-15.

Mutondo, J., R. Mate, E. Magaia, R. Borguete, and F. Mamugy. 2013. Mozambique-Country Water Resource Profile. Maputo, Mozambique: AU/NEPAD SANWATCE.

Mutondo, J., E. Tostão, and H. Zavale. 2009. Definição, Metodologia de Cálculo e Comentários sobre os Indicadores Estabelecidos no Projecto de Desenvolvimento dos Pequenos Produtores Orientados para o Mercado no Vale do Zambeze. Maputo, Mozambique: Ministério da Planificação e Desenvolvimento.

Mwalwanda, A. B., O. C. Ajayi, F. K. Akinnifesi, T. Beedy, G. Sileshi, and G. Chiundu. 2012. Impact of Fertilizer Trees on Maize Production and Food Security in Six Districts of Malawi. ICRAF Working Paper No. 140. Nairobi, Kenya: World Agroforestry Centre.

Mwase, W. F., and M. Malakini. 2012. "Effect of Three Different Cooking Technologies on Fuel Wood Consumption and Efficiency." Presentation at the National Seminar on Traditions from Traditional Biomass to Modern Bioenergy in Malawi at Capital Hotel, Lilongwe, Malawi October 2.

Nair, P. K. R. 1985. “Classification of Agroforestry Systems.” Agroforestry Systems 3: 97-128.

Nair, P. K. R., R. J. Buresh, D. N. Mugendi, and C. R. Latt. 1999. "Nutrient Cycling in Tropical Agroforestry Systems: Myths and Science.” In Agroforestry in Sustainable Agricultural System, edited by L. E. Buck, J. P. Lassoie, and E. C. Fernandes, 1-31. Boca Raton, FL: CRC Press.

National Imagery and Mapping Agency. 1997. "National Imagery and Mapping Agency Established.” Accessed September 27, 2015. https://cryptome.org/jya/nima.htm.

Naylor, R., A. Liska, M. Burke, P. Falcon, J. Gaskell, S. Rozelle, and K. Cassman. 2007. “The Ripple Effect: Biofuels, Food Security, and the Environment." Environment 49 (9): 30-43.

Nelson, A. 2008. Travel Time to Major Cities: A Global Map of Accessibility. Luxembourg: Office for Official Publications of the European Communities.

Nhantumbo, I., and A. Salomão. 2010. Biofuels, Land Access and Rural Livelihoods in Mozambique. London: International Institute for Environment and Development

Nkhoma, B. G., and W.O. Mulwafu. 2004. "The Experience of Irrigation Management Transfer in Two Irrigation Schemes in Malawi, 1960s-2002." Journal of Physics and Chemistry of the Earth, Parts $A / B / C, 29(15-18): 1327-1333$.

Nkonya, E., J. Pender, K. Kaizzi, E. Kato, S. Mugarura, H. Ssali, and J. Muwonge. 2008. Linkages between Land Management, Land Degradation, and Poverty in Sub-Saharan Africa: The Case of Uganda. IFPRI Research Report No. 159. Washington, DC: International Food Policy Research Institute. 
Nkonya, E., J. Pender, and E. Kato. 2008. "Who Knows Who Cares? Determinants of Enactment, Awareness and Compliance with Community Natural Resource Management Regulations in Uganda." Environment and Development Economics 13 (1): 79-109.

Nkonya E., F. Place, E. Kato, and M. Mwanjololo. 2014. “Climate Risk Management through Sustainable Land Management in Sub-Saharan Africa." In Climate Change, Agricultural Intensification, and Food Security, edited by R. Lal, 75-111. Cham, Switzerland: Springer International Publishing

Malawi, NSO (National Statistical Office). 2012. Integrated Household Survey 2010-2011. Zomba, Malawi.

OECD (Organization for Economic Co-operation and Development), and FAO (Food and Agriculture Organization). 2013. "Biofuels.” In OECD-FAO Agricultural Outlook 2013. Paris, France: OECD Publishing.

Ongley, E. D. 1996. Control of Water Pollution from Agriculture. Irrigation and Drainage Paper 55. Rome: Food and Agriculture Organization of the United Nations.

Orr, A. 2000. "Green Gold'?: Burley Tobacco, Smallholder Agriculture, and Poverty Alleviation in Malawi." World Development 28 (2): 347-363.

Ostrom, E. 1999. "Coping with Tragedies of the Commons.” Annual Review of Political Science 2: 493-535.

Ostrom, E., J. Burger, C. Field, R. Norgaard, and D. Policansky. 1999. "Revisiting the Commons: Local Lessons, Global Challenges.” Science 284 (5412): 278-282.

Otu, M. K., P. Ramlal, P. Wilkinson, R. I. Hall, and R. E. Hecky. 2011. "Paleolimnological Evidence of the Effects of Recent Cultural Eutrophication during the Last 200 Years in Lake Malawi, East Africa." Journal of Great Lakes Research 37 (S1): 61-74.

Ouédraogo, N. S. 2009. Bioenergy for Africa: An Illusion or a Sustainable Option to Reduce the Vulnerability to Energy and Poverty. Université Paris-Dauphine: Centre Géopolitique de l'Energie Et des Matières Premières.

Parker, J. 1994. Improving the Contribution of Forests to Food Security: A Proposed Conceptual Framework for Designing Research Studies and Practical Field Interventions. Forestry Department. Rome: Food and Agriculture Organization of the United Nation,

Pauw, K., O. Ecker, and J. Mazunda. 2011. Agricultural Growth, Poverty and Nutrition Linkages in Malawi. Malawi Strategy Support Program (MaSSP), Policy Note 8. Washington, DC: International Food Policy Research Institute.

Pauw, K., and J. Thurlow. 2011. “Agricultural Growth, Poverty, and Nutrition in Tanzania.” Food Policy 36 (6): 795-804.

Pauw, K., J. Thurlow, R. Uaiene, and J. Mazunda. 2012. Agricultural Growth and Poverty in Mozambique: Technical Analysis in Support of the Comprehensive Africa Agriculture Development Program $(C A A D P)$. Mozambique Strategy Support Program, Working Paper 2. Washington, DC: International Food Policy Research Institute

Pearson, A. W., J. C. Carr, and J. C. Shaw. 2008. “Toward a Theory of Familiness: A Social Capital Perspective." Entrepreneurship Theory and Practice 32 (6): 949-969.

Pemba, P. 2013. "Rural Electrification to Consume K6.5bn.” The Nation. Accessed January 22, 2014.http://mwnation.com/rural-electrification-consume-k6-5bn/.

Peterman, A., J. Behrman, and A. Quisumbing. 2010. A Review of Empirical Evidence on Gender Differences in Nonland Agricultural Inputs, Technology, and Services in Developing Countries. Washington, DC: International Food Policy Research Institute.

Picket, S., W. Burch, J. Grove. 1999. "Interdisciplinary Research: Maintaining the Constructive Impulse in a Culture of Criticism.” Ecosystems 2 (4): 302-307.

Piermartini, R., and R. Teh. 2005. Demystifying Modelling Methods for Trade Policy. WTO Discussion Paper 10. Geneva: World Trade Organization.

Ponce, R., F. Bosello, and C. Giupponi. 2012. Integrating Water Resources into Computable General Equilibrium Models-A Survey. Working Paper Series 57. Venice, Italy: Fondazionev Eni Enrico Mattei. 
Qaim, M., A. J. Stein, and J. V. Meenakshi. 2007. "Economics of Biofortification.” Agricultural Economics 37 (S1): 119-133.

Quisumbing, A., and L. Pandolfelli. 2009. "Promising Approaches to Address the Needs of Poor Female Farmers: Resources, Constraints, and Interventions.” World Development 38 (4): 581-592.

Ragasa, C. 2012. "Gender and Institutional Dimensions of Agricultural Technology Adoption: A Review of Literature and Synthesis of 35 Case Studies." Selected Poster prepared for presentation at the International Association of Agricultural Economists (IAAE) Triennial Conference, Foz do Iguacu, Brazil. August 18-24.

Reardon, T., and S. Vosti. 1995. "Links between Rural Poverty and the Environment in Developing Countries: Asset Categories and Investment Poverty." World Development 23 (9): 1495-1506.

Redclift, M. 1998. "Dances with Wolves? Interdisciplinary Research on the Global Environment." Global Environmental Change 8: 177-182.

Rehfuess, E. 2006. Fuel for Life: Household Energy and Health. Geneva: World Health Organization.

Rhoades, C. 1995. "Seasonal Pattern of Nitrogen Mineralization and Soil Moisture beneath Acacia albida (syn. Faidherbia albida) in Central Malawi.” Agroforestry Systems 29 (2): 133-145.

Ricker-Gilbert, J., and T. S. Jayne. 2011. What Are the Enduring Effects of Fertilizer Subsidies on Recipient Households? Staff Paper 2011-09. Department of Agricultural Food and Resource Economics. East Lansing: Michigan State University.

2012. Do Fertilizer Subsidies Boost Staple Crop Production and Reduce Poverty across the Distribution of Small-Holders in Africa? Quantile Regression Results from Malawi. Accessed March 2013. http://iaae.confex.com/iaae/iaae28/webprogram/Paper16263.html.

Ricker-Gilbert, J., T. S. Jayne, and E. Chirwa. 2011. "Subsidies and Crowding Out: A Double-Hurdle Model of Fertilizer Demand in Malawi." American Journal of Agricultural Economics 93 (1): 26-42.

Ringler, C., A. Bhaduri, and R. Lawford. 2013. "The Nexus across Water, Energy, Land and Food (WELF): Potential for Improved Resource Use Efficiency?” Current Opinion in Environmental Sustainability 5: 617-624.

Rosegrant, M. W., and the IMPACT Development Team. 2012. International Model for Policy Analysis of Agricultural Commodities and Trade (IMPACT): Model Description. Washington, DC: International Food Policy Research Institute.

Ruark, G. A., M. M. Schoeneberger, and P. K. R. Nair. 2003. “Agroforestry-Helping to Achieve Sustainable Forest Management," 1-13. UNFF (United Nations Forum for Forests) Intersessional Experts Meeting on the Role of Planted Forests in Sustainable Forest Management, New Zealand. March 24-30.

Ryan, C., and P. Walsh. 2004. "Collaboration of Public Sector Agencies: Reporting and Accountability Challenges.” International Journal of Public Sector Management 17 (7): 621-631.

SADC (South African Development Community). 2011. Regional Strategic Action Plan on Integrated Water Resources Development and Management (2011-2015)—RSAP III. Gaborone, Botswana.

Sadoulet, E., and A. De Janvry. 1995. Quantitative Development Policy Analysis. Baltimore and London: Johns Hopkins University Press.

Sahn, D., and H. Alderman. 1997. "On the Determinants of Nutrition in Mozambique: The Importance of AgeSpecific Effects." World Development 25 (4): 577-588.

Saka, A. R., W. T. Bunderson, O. A. Itimu, H. S. K. Phombeya, and Y. Mbekeani. 1994. "The Effects of Acacia albida on Soils and Maize Grain Yields under Smallholder Farm Conditions in Malawi." Forest Ecology and Management 64: 217-230.

Savic, D. 2012. "Water-Food-Energy Concept." Presentation for the workshop Avoiding the Perfect Storm: The Water-Food-Energy Nexus, University of Exeter. July 24-25. www.exeter.ac.uk/media/ universityofexeter/research/newsandevents/eventarchivematerials/water-food-energynexus/Waterfood-energy_workshop_concept.pdf.

SEI (Stockholm Environment Institute). 2011. Energy Access and Biomass Resource Transitions in Malawi. Policy Brief. LEAP Brochure. Accessed January 10, 2014. www.sei-international.org/ mediamanager/documents/Publications/Climate/sei-pb-2013-malawi-energy-access.pdf. 
2013. LEAP Brochure. Accessed January 10, 2014. www.sei-us.org/Publications_PDF/SEI-LEAPbrochure-Jan2012.pdf.

Shah, T., B. van Koppen, D. Merrey, M. de Lange, and M. Samad. 2002. Institutional Alternatives in African Smallholder Irrigation: Lessons from International Experience with Irrigation Management Transfer. Research Report 60. Colombo, Sri Lanka: International Water Management Institute.

Simler, K., and V. Nhate. 2005. Poverty, Inequality and Geographic Targeting: Evidence from Small-Area Estimates in Mozambique. Food Consumption and Nutrition Division, Discussion Paper 192. Washington, DC: International Food Policy Research Institute.

Smakhtin, V., and C. Ringler. 2013. Increasing Synergies and Reducing Trade-offs along the Water-EnergyFood Nexus (WE4FOOD). http://wle.cgiar.org/blogs/files/2013/05/W4E.pdf.

Strasberg, P. 1997. "Smallholder Cash-Cropping, Food-Cropping and Food Security in Northern Mozambique." Ph.D. dissertation. Department of Agricultural Economics. East Lansing: Michigan State University.

Strauss, J., and D. Thomas. 1998. "Health, Nutrition, and Economic Development." Journal of Economic Literature 36 (2): 766-817.

Sustainable Engineering Lab. 2009. “Cookstove Study.” Accessed October 21, 2015. http://sel.columbia.edu/ cookstove.

Takama, T., F. Lambe, F. X. Johnson, A. Arvidson, B. Atanassov, M. Debebe, L. Nilsson, P. Tella, and S. Tsephel. 2011. Will African Consumers Buy Cleaner Fuels and Stoves? A Household Energy Economic Analysis Model for the Market Introduction of Bio-Ethanol Cooking Stoves in Ethiopia, Tanzania, and Mozambique. Stockholm, Sweden: Stockholm Environment Institute.

Thaler, K. 2013. "Brazil, Biofuels, and Food Security in Mozambique." In Agricultural Development and Food Security in Africa: The Impact of Chinese, Indian and Brazilian Investments, edited by R. Modi and F. Cheru, 145-158. London: Zed Books.

Thurlow, J. 2012. "Mozambique." In Strategies and Priorities for African Agriculture: Economy wide Perspectives from Country Studies, edited by X. Diao, J. Thurlow, S. Benin, and S. Fan, 349-370. Washington, DC: International Food Policy Research Institute.

Tschirley, D., and D. Abdula. 2007. Toward Improved Marketing and Trade Policies to Promote Household Food Security in Central and Southern Mozambique: 2007 Update. Research Report No 62 E. Maputo, Mozambique: Ministry of Agriculture.

Tschirley, D. L., and R. Benica. 2001. "Smallholder Agriculture, Wage Labor and Rural Poverty Alleviation in Land-Abundant Areas of Africa: Evidence from Mozambique." The Journal of Modern African Studies 39 (2): 333-358.

Uaiene, R. 2008. Determinants of Agricultural Technical Efficiency and Technology Adoption in Mozambique. West Lafayette, IN, US: Center for Global Trade Analysis, Purdue University.

UN (United Nations). 2012. "Ban Urges Integrating Environmental, Social and Economic Aspects of Development." Accessed November 22, 2013. www.uncsd2012.org/index.php?page=viewandnr= 980andtype=230andmenu=39. Created March 17, 2012.

UN (United Nations) Energy. 2011. Global Alliance for Clean Cookstoves. Accessed September 27, 2015. www.un-energy.org/stories/39-global-alliance-for-clean-cookstoves.

UN (United Nations) Water. 2013. Water Security and the Global Water Agenda. A UN-Water Analytical Brief. Hamilton, Ontario, Canada: United Nations University Institute for Water, Environment and Health (UNU-INWEH).

UNDP (United Nations Development Programme). 2005. Energizing the Millennium Developing Goals: A Guide to Energy's Role in Reducing Poverty. New York: UNDP.

. 2013. Renewables 2013. Global Status Report. Accessed June 23, 2014.www.ren21.net/.

UNDP (United Nations Development Programme) Malawi. 2007. Feasibility Study for the Use of Ethanol as a Household Cooking Fuel in Malawi. Draft Final Report. Lilongwe, Malawi: Ethio Resource Group Pvt. Ltd.

UNEP (United Nations Environmental Programme). 2007. Global Environmental Outlook 4. Valletta, Malta: Progress Press Company Limited. 
2014. Illegal Trade in Wildlife: The Environmental, Social and Economic Consequences for Sustainable Development. UNEP/EA.1/INF/19. Nairobi, Kenya.

UNESCO (United Nations Educational, Scientific and Cultural Organization). 1987. United Nations University: Annual Report by the Council of the United Nations University and Report by the Director-General. 126th Session in Paris, France. http://unesdoc.unesco.org/images/0007/000750/075061 eo.pdf. April 17 , 1987.

United States Government Accountability Office. 2014. Implementation Approaches Used to Enhance Collaboration in Interagency Groups. Managing for Results. Report to Congressional Addressees. GAO-14-220. Washington, DC.

Unruh, J. D. 2002. "Land Dispute Resolution in Mozambique: Institutions and Evidence of Agroforestry Technology Adoption.” In Innovation in Natural Resource Management: The Role of Property Rights and Collective Action in Developing Countries, edited by R. Meinzen-Dick, A. Mcculloch, F. Place, and B. Swallow. London: Johns Hopkins University Press.

USGS (United States Geological Survey). 2015. Shuttle Radar Topography Mission Data. Accessed September 27, 2015. http://srtm.usgs.gov/.

Von Hellens, A. 2013. Groundwater Quality of Malawi: Fluoride and Nitrate of the Zomba-Phalombe Plain. First Cycle, G2E. Dept. of Soil and Environment. Uppsala, Sweden: Swedish University of Agricultural Sciences,

Watson, R. T., I. R. Noble, B. Bolin, N. H. Ravindranath, J. D. Verarda, and D. J. Dokken. 2000. Land-use, Land-use Change and Forestry. IPCC Special Report. Cambridge, UK: Cambridge University Press.

WEAP21. 2014. Water Evaluation and Planning. Accessed January 10, 2014. www.weap21.org/index.asp.

Welsh, M., S. Hermann, M. Howells, H. H. Rogner, C. Young, I. Ramma, M. Bazilian, G. Fischer, T. Alfstad, D. Gielen, D. Le Blanc, A. Röhrl, P. Steduto, and A. Müller. 2014. “Adding Value with CLEWSModelling the Energy System AND Its Interdependencies for Mauritius.” Applied Energy 113: 14341445 .

WHO (World Health Organization). 2015. WHO Household energy database. Accessed November 10, 2015. http://www.who.int/indoorair/health_impacts/he_database/en/

WHO (World Health Organization) and UNDP (United Nations Development Programme). 2009. The Energy Access Situation in Developing Countries: A Review Focusing on the Least Developed Countries and Sub-Saharan Africa. New York: UNDP.

WHO (World Health Organization) and UNICEF (United Nations Children's Fund). 2013. Progress on Sanitation and Drinking Water: 2013 Update. New York: WHO. www.wssinfo.org/fileadmin/user_upload/resources/JMPreport2013.pdf.

Wilkins, P. 2002. “Accountability and Joined-Up Government.” Australian Journal of Public Administration 61 (1): 114-119.

Wing, I. S. 2004. Computable General Equilibrium Models and Their Use in Economy-Wide Policy Analysis: Everything You Ever Wanted to Know (But Were Afraid to Ask). MIT Joint Program on the Science and Policy of Global Change, Technical Note No. 6. Cambridge, MA, US: Massachusetts Institute of Technology.

World Bank. 2011a. "World Bank Invests in Malawi’s Electricity Supply System.” Press Release. Accessed January 21, 2014. www.worldbank.org/en/news/press-release/2011/06/28/world-bank-invests-inmalawis-electricity-supply-system.

—. 2011b. Mozambique: Analysis of Public Expenditure in Agriculture. Washington, DC.

2012. Agribusiness Indicators: Mozambique. Washington, DC.

World Business Council for Sustainable Development, n.d. Accessed December 4, 2013. www.wbcsd.org/workprogram/sector-projects/water/waterenergyfood.aspx.

World Economic Forum. 2011. Water Security: The Water-Food-Energy-Climate Nexus. The World Economic Forum Water Initiative. Washington, DC: Island Press.

WWF (World Wide Fund for Nature). 2008. Mozambique Consultancy Report on Biofuel Study. Stockholm, Sweden. 
Xie, H., L. You, B. Wielgosz, and C. Ringler. 2014. "Estimating the Potential for Expanding Smallholder Irrigation in Sub-Saharan Africa." Agricultural Water Management 131: 183-193.

You, L., C. Ringler, U. Wood-Sichra, R. Robertson, S. Wood, T. Zhu, G. Nelson, Z. Guo, and Y. Sun. 2011. "What Is the Irrigation Potential for Africa? A Combined Biophysical and Socioeconomic Approach." Food Policy 36 (6): 770-782. 


\section{RECENT IFPRI DISCUSSION PAPERS}

\section{For earlier discussion papers, please go to www.ifpri.org/pubs/pubs.htm\#dp. All discussion papers can be downloaded free of charge.}

1479. The making of public investments: Champions, coordination, and characteristics of nutrition interventions, Tewodaj Mogues and Lucy Billings, 2015.

1478. The dynamics of smallholder marketing behavior: Explorations using Ugandan and Mozambican panel data. Bjorn Van Campenhout, 2015.

1477. Adjusting to external shocks in small open economies: The case of Honduras. Samuel Morley and Valeria Piñeiro, 2015.

1476. Drivers of growth in agricultural returns to scale: The hiring in of tractor services in the Terai of Nepal. Hiroyuki Takeshima, 2015.

1475. The contribution of increased equity to the estimated social benefits from a transfer program: An illustration from PROGRESA. Harold Alderman, Jere R. Behrman, and Afia Tasneem, 2015.

1474. Reconstructing public expenditure data: Use of classification systems to better measure public spending in agriculture - A Mozambique case study. Tewodaj Mogues, Leonardo Caceres, Francisco A. Fernandez, and Mariam B. Umarji, 2015

1473. Agricultural insurance and the World Trade Organization. Joseph W. Glauber, 2015.

1472. Grain price and volatility transmission from international to domestic markets in developing countries. Francisco Ceballos, Manuel A. Hernandez, Nicholas Minot, and Miguel Robles, 2015.

1471. Policy changes in times of crisis: Evidence from the Arab Spatial Policy Analyzer. Jacopo Bordignon and Clemens Breisinger, 2015.

1470. Gender empowerment gaps in agriculture and children's well-being in Bangladesh. Hazel Jean L. Malapit, Esha Sraboni, Agnes R. Quisumbing, and Akhter Ahmed, 2015.

1469. Climate change adaptation in agriculture: Ex ante analysis of promising and alternative crop technologies using DSSAT and IMPACT. Sherman Robinson, Daniel Mason-D'Croz, Shahnila Islam, Nicola Cenacchi, Bernardo Creamer, Arthur Gueneau, Guy Hareau, Ulrich Kleinwechter, Khondoker Mottaleb, Swamikannu Nedumaran, Richard Robertson, Mark W. Rosegrant, Gbegbelegbe Sika, Timothy B. Sulser, Keith Wiebe, 2015.

1468. A proximity-based measure of industrial clustering. Jianqing Ruan and Xiaobo Zhang, 2015.

1467. Aspirations and the role of social protection: Evidence from a natural disaster in rural Pakistan. Katrina Kosec and Cecilia Hyunjung Mo, 2015.

1466. Addressing human capital development in public agriculture extension in southern Africa: Assessing Mozambique's experience. Hélder R. Gêmo and Kristin E. Davis, 2015.

1465. Microinsurance decisions: Gendered evidence from rural Bangladesh. Daniel J. Clarke and Neha Kumar, 2015.

1464. Institutions and market integration: The case of coffee in the Ethiopian commodity exchange. Manuel A. Hernandez, Shahidur Rashid, Solomon Lemma, and Tadesse Kuma, 2015.

1463. Happiness in the air: How does a dirty sky affect subjective well-being? Xin Zhang, Xiaobo Zhang, and Xi Chen, 2015.

1462. The impact of the use of new technologies on farmers' wheat yield in Ethiopia: Evidence from a randomized controlled trial. Gashaw Tadesse Abate, Alan de Brauw, Nicholas Minot, and Tanguy Bernard, 2015.

1461. Living like there's no tomorrow: Saving and spending following the Sichuan earthquake. Mateusz Filipski, Ling Jin, Xiaobo Zhang, and Kevin Chen, 2015.

1460. Agricultural value chain development in practice: Private sector-led smallholder Development. Shashidhara Kolavalli, Akwasi Mensah-Bonsu, and Saima Zaman, 2015.

1459. Cropping Intensity gaps: The potential for expanding global harvest areas. Wenbin Wu, Liangzhi You, and Kevin Chen, 2015.

1458. Migration, gender, and farming systems in Asia: Evidence, data, and knowledge gaps. Valerie Mueller, Chiara Kovarik, Kathryn Sproule, and Agnes Quisumbing, 2015.

1457. Los efectos de la roya en las economías Centroamericanas. Valeria Piñeiro, Samuel Morley, and Pablo Elverdin, 2015. 
INTERNATIONAL FOOD POLICY RESEARCH INSTITUTE

\section{www.ifpri.org}

\section{IFPRI HEADQUARTERS}

2033 K Street, NW

Washington, DC 20006-1002 USA

Tel.: +1-202-862-5600

Fax: +1-202-467-4439

Email: ifpri@cgiar.org

IFPRI LILONGWE OFFICE

PO Box 31666

Lilongwe 3

Malawi

Tel.: +265-1-789747

Email: IFPRI-Lilongwe@cgiar.org

IFPRI KAMPALA

15 East Naguru Road

Kampala

Uganda

Tel.: +256-41-285-060/4; +256-312-226-613

Fax: +256-41-285-079

Email: ifpri-Kampala@cgiar.org 